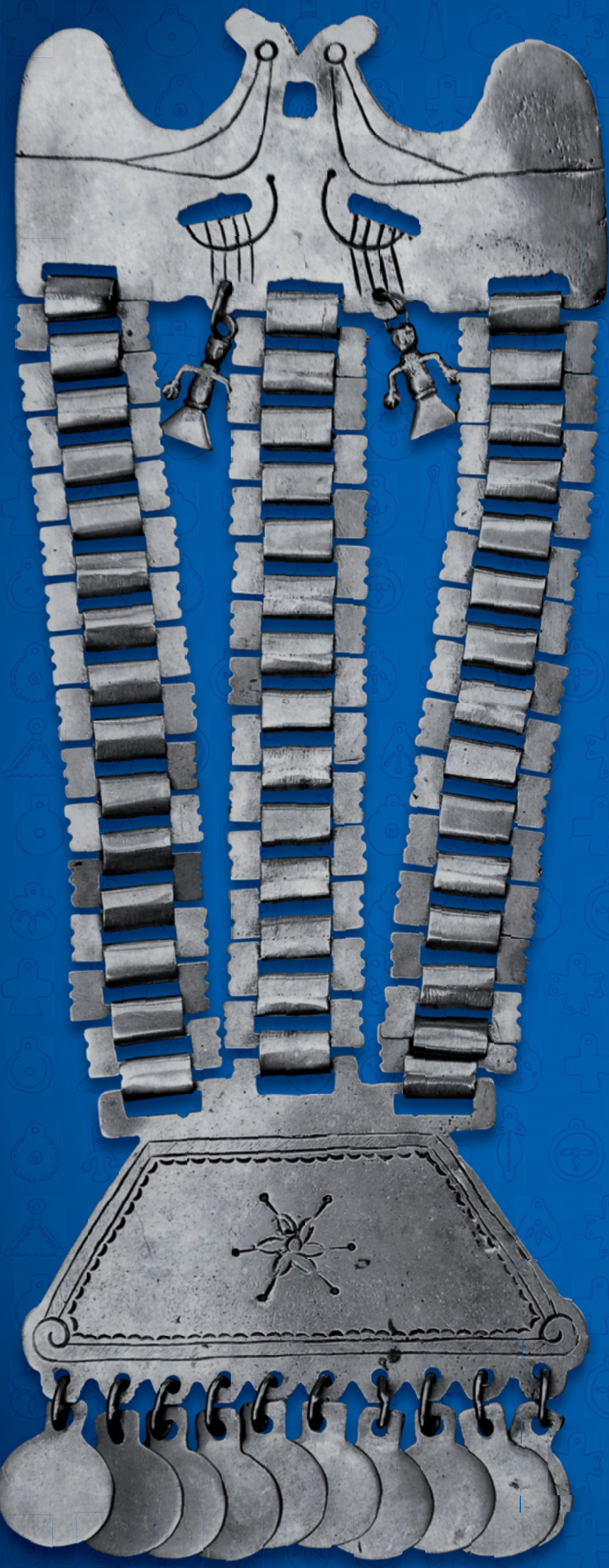

\author{
Juan Painecura Antinao
}

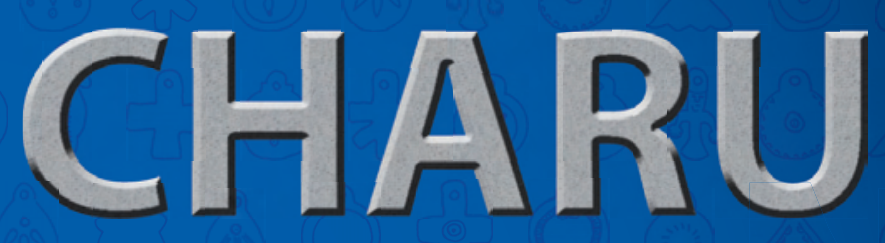

\title{
Sociedad y Cosmovisión en la Platería Mapuche
}
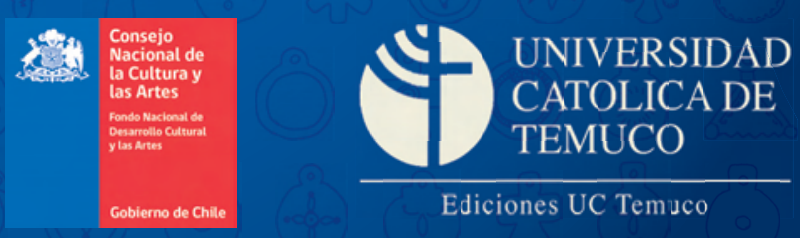

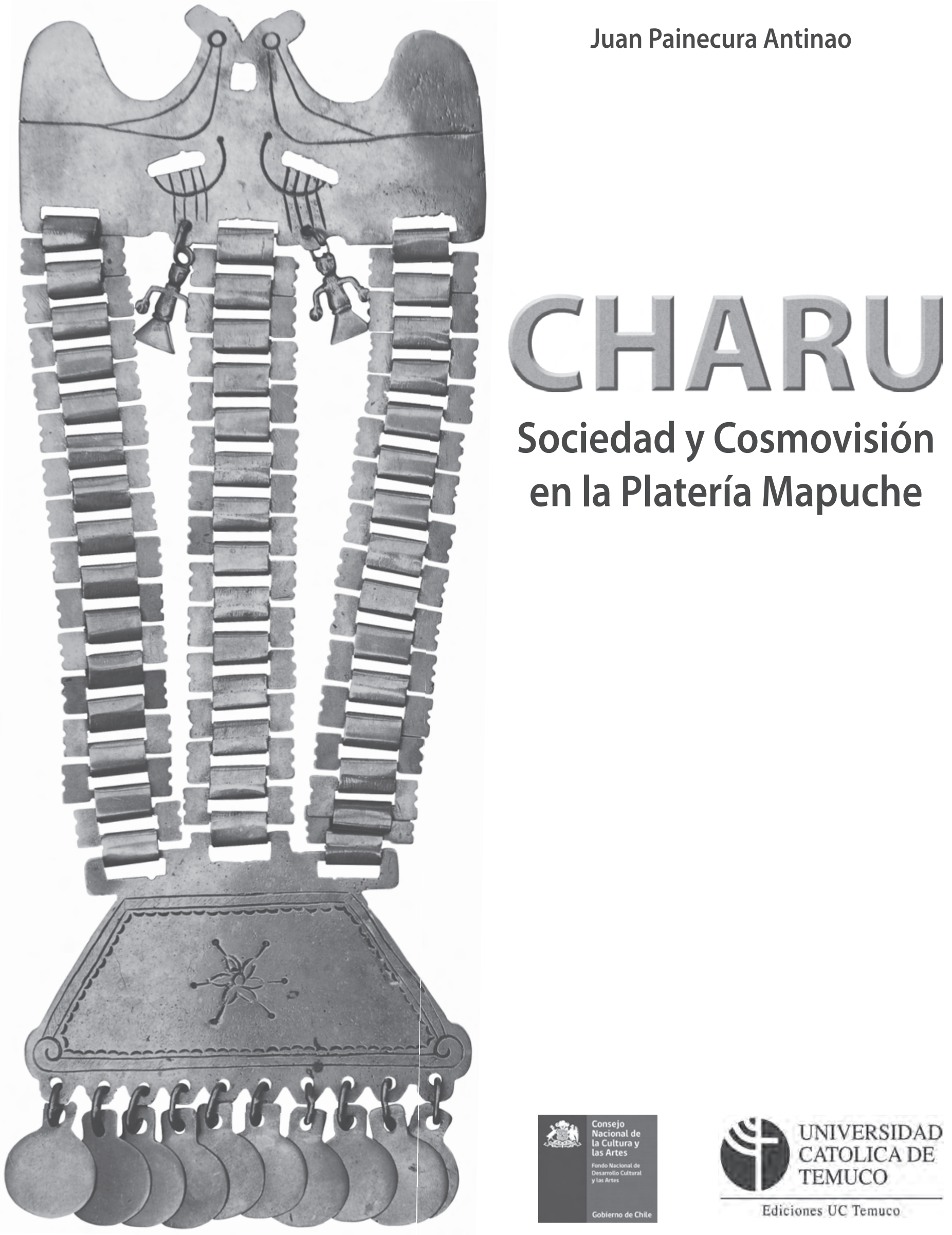
Este libro contó con el apoyo y financiamiento de los Fondos Concursables de Consejo Nacional de la Cultura y las Artes, 2010.

(c) Juan Painecura Antinao

ISBN: 978-956-7019-77-9

Registro de Propiedad Intelectual N²11.504

Primera Edición, noviembre de 2011

Ediciones Universidad Católica de Temuco

Avenida Alemania 0211, Temuco

mail: editorial@uctemuco.cl

Fono: 045-205253

Edición mapuche y mapuzugun

José Quidel Lincoleo

Fotografías

Patricia Pichún Carvajal

llustraciones

Lucas Cioffi

Diseño y diagramación

Alfabeta Artes Gráficas

Fono: 02-3649242

IMPRESO EN CHILE/PRINTED IN CHILE 


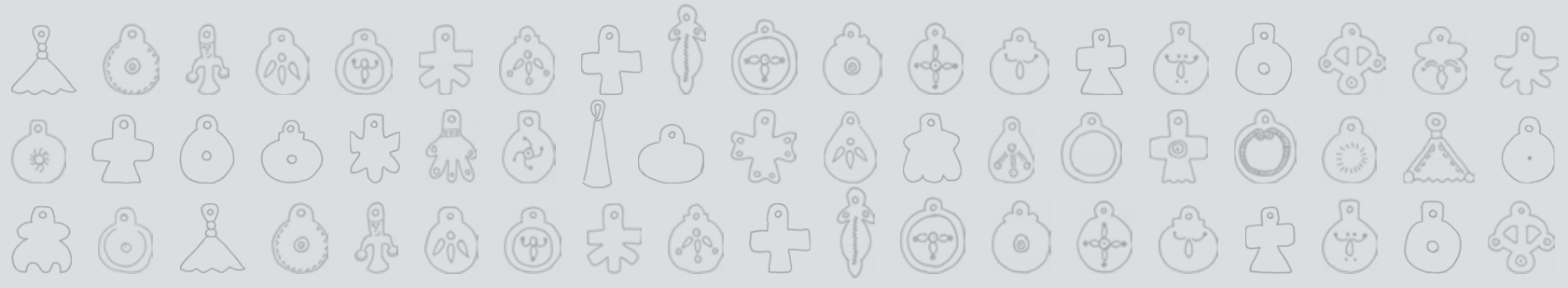

\section{Índice}

$\begin{array}{lr}\text { Chalintukun } & 7\end{array}$

$\begin{array}{lr}\text { Prefacio } & 9\end{array}$

$\begin{array}{ll}\text { Presentación } & 11\end{array}$

$\begin{array}{ll}\text { Introducción al texto } & 15\end{array}$

Primera parte: Fundamentos del origen de la Platería Mapuche 19

- Invasiones del Imperio Inca 19

- Invasión del Imperio Español 21

- Profundos cambios en el pueblo mapuche 23

- El esplendor de la Platería Mapuche 27

- Análisis del desarrollo técnico de la Platería Mapuche 29

- Fundamentos de la decadencia de la Platería Mapuche 31

- Algunas conclusiones preliminares 34

$\begin{array}{ll}\text { Clasificación de la Platería Mapuche } & 37\end{array}$

Situación de la Platería Mapuche subordinada al Estado de Chile 39

Situación actual de la Platería Mapuche 41

Segunda parte: Bases filosóficas-espirituales $\quad 45$

- Primera idea: cómo se generó la vida 45

- Segunda idea: cómo se genera la vida humana mapuche 47

- Tercera idea: quiénes controlan y administran el funcionamiento de la vida de la naturaleza en general y de la vida humana mapuche 49

- Cuarta idea: cómo es la relación entre la vida y la muerte en el mundo mapuche 54

- Quinta idea: las formas espaciales del wajmapu 58

- Sexta idea: cómo se sostiene el wajmapu 62

- Séptima idea: cómo nace el pueblo mapuche 63

- Interpretación del xarilogko 65

Algunas consideraciones finales acerca de la Platería Mapuche 67 



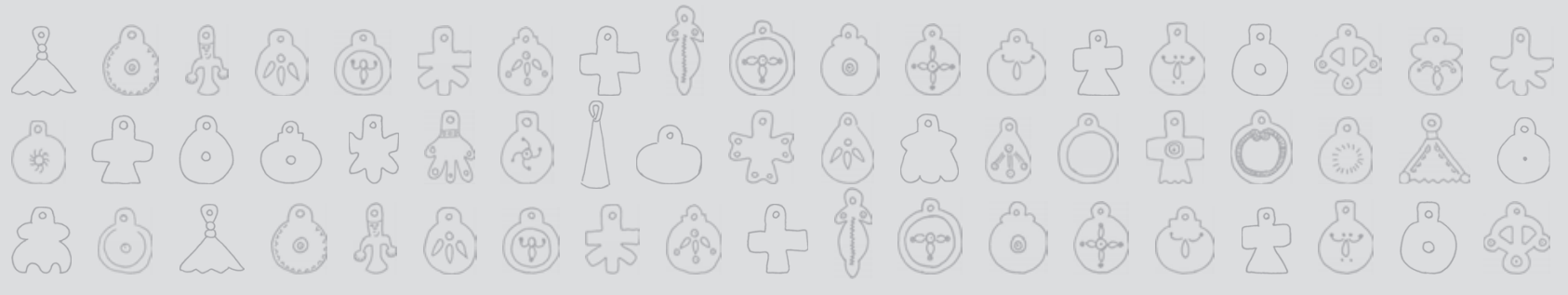

\section{Chalintukun}

Mari mari kom pu che petu chijkatulu tufa chi küzaw.

Fantepu, xipankepiyey fijke küzaw foliluwküleyelu mapuche rakizuam mew, mapuche mogen mew, fey tüfa chi wirintuku zugu nüwküley rüxan zugu mew, kiñe peñi rüxafe che, kuyfi mew zew amulnielu tüfachi küzaw ayiy ñi wirintukuael ñi kimün, ñi rakizuam, ñi elelgenchi zugu, ka ñi kisu yompu azümürpun mogen mew.

Chalintukulelan fey tüfa chi küzaw pienew, feymew ta petu wirintukun kiñeke xoy zugu fey ñi küzaw mew. Zew kuyfigetuy ñi kimfiel fey tüfachi peñi. Pegelkeawül-lu ñi rüxan küzaw, welu pekan rüxan gelay, kümeke küzaw, ayüfal-lu, wilüfchi rüxan, ragawlu, azelka zomopelu, fey mew amuy yu wehüykawün. Fenxen che zewmalyefiy fijke xipa rüxan, fijke xipa küzaw, pu zomo, pu wenxu, lof mew müleyechi pu che, ka wareawküleyelu ka fey, welu kom ñi küzaw küme rüxafiy, küme nentufiy, küme pepikafiy, ka fey ñi fanekontuam ta mapuche rüxan, fanekontuam ta iñ pu zomo, küme azgetuam, aztuam, ta iñ wenuntuwtual kümeke che reke, kümeke küpangelu, kümeke tuwüngelu, kümeke zugu wixampelu; gijatun, mafün, katawün, welu kom feychi kümeke xawün ka müley ñi kümeke tukutuwal ta iñ pu zomo, ta iñ pu ñawe, ta iñ pu zeya, ta iñ pu mabeh.

Kuyfi mew echa kümeke rüxantukefuy ta iñ pu che yem, welu akulelgelu fija zugu iñchiñ, pegengewelay kümeke tukutuwün. Akulelgelu iñchiñ muntukan zugu, waj lefyey ta iñ pu cheyem ñi ejkayal ñi kümeke rüxan em. Ka akulelgelu güñin zugu iñchiñ lefyey ta iñ pu wünenke che yem ñi empeñawal warea mew, fey mew püxün kümeke rüxan em punzipuy, ñamnaüqpuy gewenolu rag ñi nentugetual. Fey mew fey tüfa chi rüxan fenxen zugu yeniey, ka femgechi pekan zugu gelay.

Kümeke rüxan ta igkachepelu, montulchepelu, bawehtuwün mew ta konpelu, fey mew ta fanen zugugey. Zatun zugu mew tukugekey, fey ñi jowzuguam kiñeke zugumachife kiñeke püjü ayikey ñi nielgeael feychi rüxan.

Fenxen zugu mülefuy fey ti rüxan zugu mew, welu müleay ka ahtü ñi xipaleael fey tüfachi zugu. Iñche ñi güxam fente puway, eymün ka müleymün ñi kimtukuyeal feyta chi zugu ka mün amulnieael fey ñi kimgeael, ta iñ pu wekeche ñi piwkentukual, ka logkontukuyeael kom feytachi rüxanke zugu. 



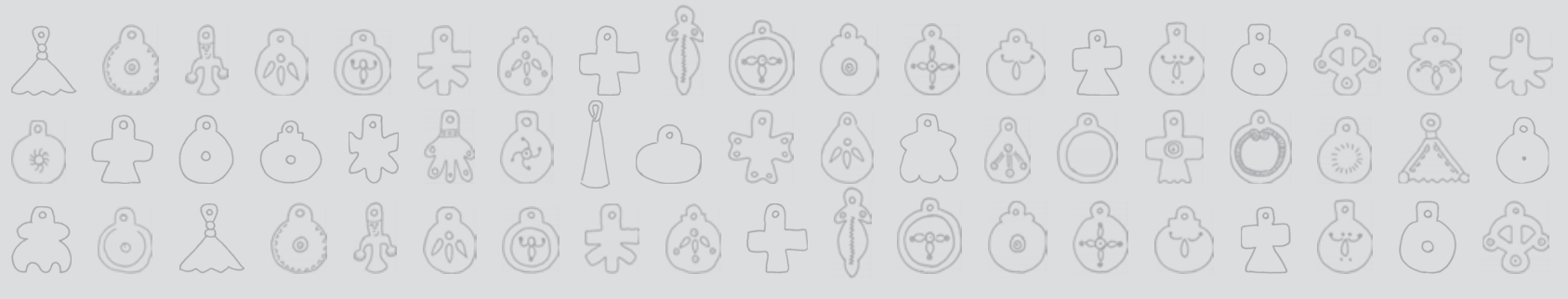

\section{Prefacio}

El presente ensayo del reconocido rüxafe Juan Antonio Payne-Kura Ahtü-Nawel (Painecura Antinao), constituye un importante legado de un activo orfebre mapuche. Estamos frente a uno de los pocos rüxafe que conservó técnica, estilo y por sobre todo la fundamentación filosófica del trabajo de mapuche rüxan (platería mapuche). Pero ¿qué es el rüxan? Si bien es el trabajo de los metales, es por excelencia el trabajo fino de los metales, es el arte mapuche que se expresa en la plasmación de ideas filosóficas, esta vez, a través de la plata.

En estas líneas quiero además consignar el rüxan como un arte mapuche y no como una expresión de la artesanía mapuche como se ha venido señalando en diferentes espacios y medios de transmisión de opiniones, ideas, y hasta conocimiento. Este es un viejo problema de relación colonial que hemos heredado y que debemos asumir la responsabilidad de resituarlo en el contexto actual desde una perspectiva descoIonizadora. Las innumerables expresiones artísticas del pueblo mapuche como el rüxan (orfebrería), wizün (alfarería), ülkantun (canto y poesía), ñimikan (diseños en el telar), por nombrar algunos son parte del arte mapuche y no una expresión artesana como suelen tildar los escritos bajo la influencia integracionista y etnocéntrica poniendo sus criterios estéticos monoculturales como universal dentro de un mundo poblado de diversidad que no alcanzan siquiera a dimensionar en su real magnitud. La permanente porfía de ciertos sectores empoderados desde los inicios de mala relación indígena y no indígena en folclorizar las expresiones de aquellas "otras" sociedades no se ha detenido. Desde el mapuzugun el término artesano no existe ni algo que se aproxime a las ideas de subcategorías que en español existen quizás por empeñarse el clasismo por imponerse.

Los rüxafe son los que trabajan los metales, los wizüfe son los que construyen formas en greda, pero no son subcategorías en la sociedad mapuche, que sí lo son en relación con el otro mundo no mapuche. Creo que el texto testimonial de Juan Antonio Painecura demuestra lo trascendente del arte mapuche del rüxan al explicar los significados que se imprimen en cada trabajo, en cada pieza de la riquísima expresión orfebre mapuche.

En este mismo tenor, creo que es importante destacar en este texto la posición clara, definida, que el autor toma acerca de ciertos temas que aún no han tenido una posición, como es el caso de hablar derechamente de "religión mapuche", sacando con ello a la expresión religiosa mapuche también de los submundos conceptuales a las que nos destinan la elite clasista e integracionistas. Sacarnos de la "religiosidad", de la "creencias", "espiritualidad" que no interpreta en plenitud el acervo religioso mapuche. Ahora bien, quizás la categoría de "religión" tampoco nos interprete plenamente, pero por lo menos estamos ubicándonos en peldaños conceptuales más simétricos para entrar a dialogar en serio con las otras sociedades. Pero la discusión no está terminada, este texto es una clara provocación a la reflexión, a la discusión, una invitación a tomar posiciones a partir de un ensayo basado en la expresión artística. 


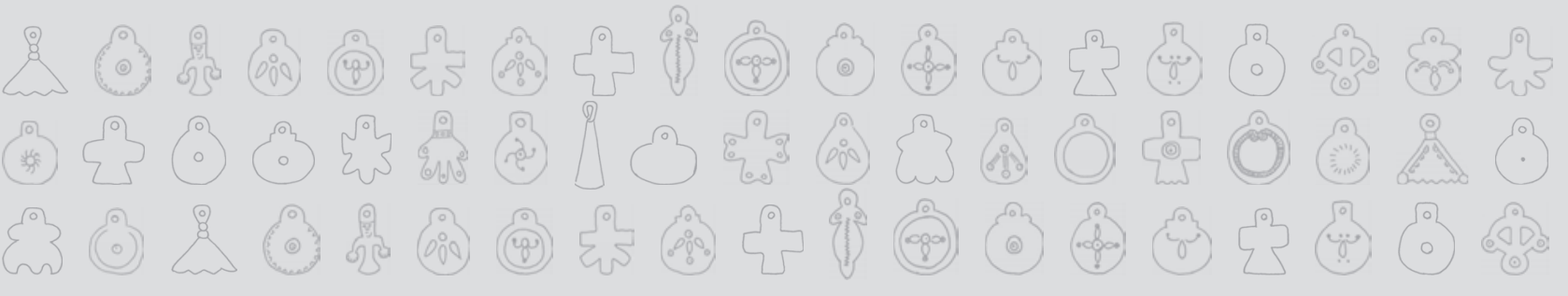

También es destacable hablar desde una posición definida como lo hace Juan Antonio desde su experiencia como mapuche que tiene un pasado de emigrante, de relaciones rotas, relaciones restablecidas, búsquedas desde un epicentro claro, el rüxan. Ello nos prueba la teoría mapuche del chegen, en el sentido de que cada persona posee una fuerza y nexos propios que debe desarrollar para lograr el estado de "che", al culminar su tránsito por este mapu (dimensión).

Muchísima gente de la región, del país y de varios países, son testigos y portadores de los trabajos de Juan Antonio, ellos han trascendido el Gulu Mapu (parte sur del que ahora es territorio chileno) por su gran calidad, estilo e impronta que poseen, por tal razón dan fe de la excelente mano de este rüxafe.

Rüxan es un término que alude a un ejercicio de paciencia, finura, temple, comunicación, contemplación y es el ejercicio de materializar las dimensiones etéreas del mapuche rakizuam (pensamiento mapuche), entiéndase aquí el mapuche rakizuam como la filosofía mapuche.

La filosofía mapuche comienza a emerger también cada vez más con mayor claridad y voces. Los escritos mapuche sobre su visión de mundo, sobre su filosofía no es nueva, el rüxan ya la había impreso, con esto se está dando un argumento muy importante de las "formas" de inscripción, de escritura que los pueblos, las sociedades realizan y que es deber de las actuales generaciones poder descifrar, exponer y enseñar.

Otro aporte y desafío de este texto es el recurso o contraparte discursiva que algunas autoridades mapuche hacen en este texto. Un aporte basados en el güxam, método dialógico por excelencia del mapuche rakizuam, en donde se explicitan las ideas desde un instante reflexivo provocado por el interlocutor. Aquí las voces mapuches analizan, expresan sus kimün (conocimiento) acerca del rüxan, sus implicancias, dimensiones y alcances en diferentes dimensiones de la vida del mapuche, tanto en lo económico, social, político y religioso, forman parte de una explicación filosófica de lo que significa mapuchegen (ser mapuche)

Un ensayo interesante que a través de una idea central, como lo es la platería, se pueden abarcar diferentes procesos como la historia, la economía, la cosmovisión, la política, es como un mapuche güxam que a partir de un tema se puede al mismo tiempo ir incorporando otras ideas, otros procesos de manera de hacer siempre integral el enfoque y no caer en las parcialidades desvinculadoras y lineales que se transforman en discursos excluyentes.

El grafemario utilizado en este texto es el wiyilzuguwe, al serle grafemario que surge incorporado algunos cambios, como cualquier sistema de escritura que son perfectibles en el tiempo, pero manteniendo la base propuesta por el difunto maestro don Anselmo Ragileo.

José Quidel Lincoleo 


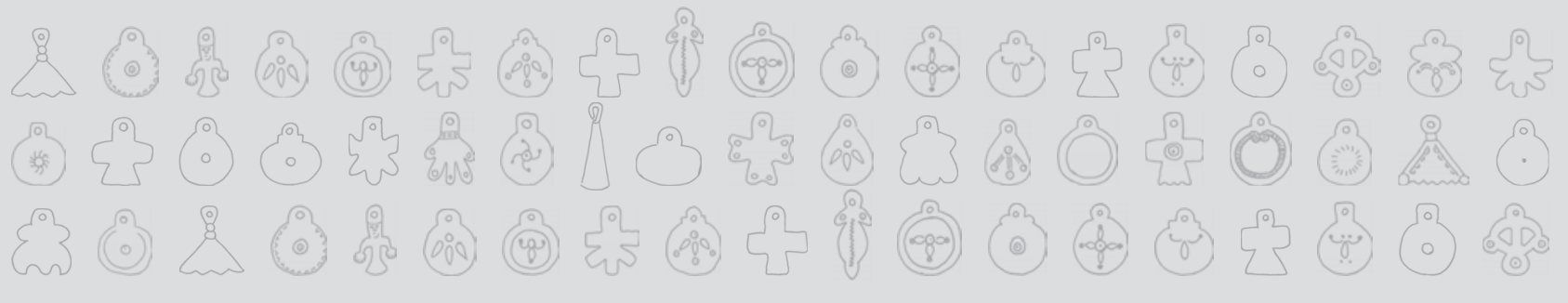

\section{Presentación}

Mi nombre es Juan Antonio Painecura Antinao, tengo casi 59 años de edad y mi Lof es Kuwelche, queda entre Nueva Imperial y Cholchol (en la parte norte del puente sobre el río Cholchol), soy casado y tengo cuatro hijos, en estos momentos solo está conmigo mi hijo menor, Lincoyan, quien tiene casi 19 años y estudia en la Universidad Católica de Temuco. Mi padre se llama Antonio Painecura Huircapán tiene 84 años y vive actualmente en la ciudad de Santiago y mi madre se llamaba Ñasky Antinao Millao quien falleció hace ya 7 años, los hijos de ese matrimonio somos 4, dos hombres y dos mujeres, siendo yo el mayor. Actualmente vivo en una comunidad de Maquehue y me dedico a construir joyas mapuche ya que soy rüxafe. Por estos tiempos todavía tengo mucha familia en el lof Kuwelche, mi küpan por parte de mi padre es la principal y más importante mi abuelita Magdalena Huircapán Pilquil y mi tía Celinda Painecura Huircapán hermana de mi padre y en el lof de Kautinche y Rumulwe la familia de origen de mi madre estando ahí la familia de mi tío Melinao Antinao Millao y de mi tía Huenchul Antinao Millao ambos hermanos de mi madre con muchos hijos todos primos míos.

Tanto por la línea de mi padre y de mi madre se han tenido roles y papeles importantes y principales en rewe y ayjarewe siendo uno de los más destacados mi bisabuelo Painecura quien participó en alianzas con los puwelche (gente del lado oriental del territorio mapuche) para desarrollar la guerra en contra del Estado de Chile y de Argentina; es de mucha importancia para mi familia mi bisabuelo por la línea de mi madre que se llamaba Antünao, quien combatió y formó parte de las fuerzas que dirigía el logko Antonio Painemal en la guerra contra el Estado chileno en los años 1881 y 1883.

El tuwün (origen territorial) de mi familia por parte de padre y madre es un lugar llamado Kolwe, que se encuentra en las cercanías de Boroa, en esos lugares habían llegado la congregación de los Capuchinos a principios de los años 1800, se establecieron ahí con la autorización de los logko principales, construyeron una iglesia, un dispensario de salud y una escuela, dando comienzo a sus trabajos de evangelización. Pasados varios años, los curas se reunieron con los logko para explicarles que los niños habían terminado con el aprendizaje básico y que treinta niños, 15 hombre y 15 mujeres debían continuar con sus estudios en tierras al otro el lado del mar y que cuando regresaran tendrían tanto conocimiento y sabiduría como ellos (los curas). Los logko tuvieron un gran xawün (una gran reunión) para tomar una decisión y dar respuesta a los curas, algunos de los logko estuvieron de acuerdo y otros no, pero al final se fueron 15 niños de ambos sexos, el acuerdo fue que al cabo de tres años los niños volverían a sus familias, el resultado de este episodio es que los niños nunca volvieron y hubo nuevamente un xawün (reunión) entre los logko que habían entregados a sus hijos y decidieron arrasar con todas las instalaciones y aniquilar a todos los curas, como respuesta al agravio que se había cometido contra ellos por la pérdida de sus hijos y así se hizo. Se debe destacar que el escenario de confrontación que vivían los españoles y los criollos (posteriormente chilenos) hacía que todas las actividades: militares, sociales, políticas y económicas se desarrollaran en la zona central, esta situación demora la respuesta militar española a la decisión ya ejecutada por los lofche de Boroa. 


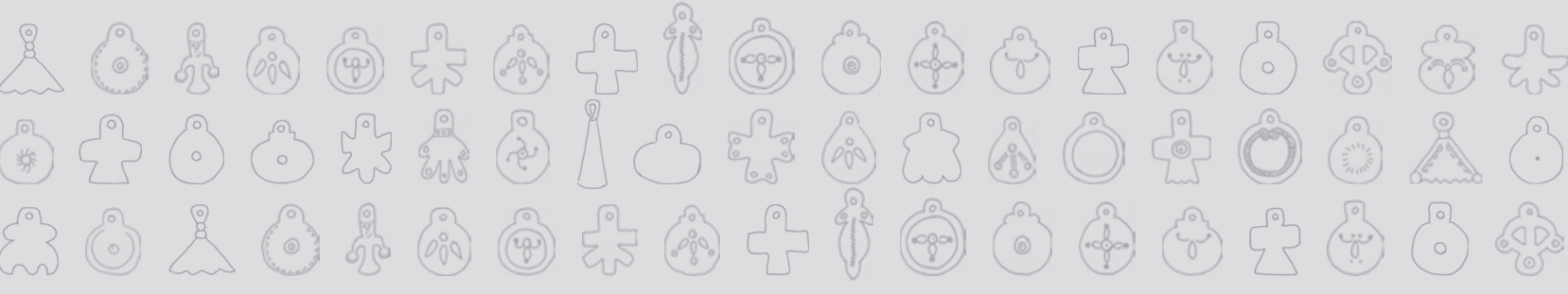

Al cabo de algún tiempo se tuvo noticias que llegarían tropas españolas para castigar a los logko que habían participado en esa destrucción y aniquilamiento de españoles, los logko de esos territorios se reunieron y acordaron que los lofche que habían participado debían buscar otros lugares en el cual deberían establecerse para que la represalia no cayera sobre los lofche que no habían participado, salieron entonces exploradores en tres direcciones: de la cordillera de los Andes, del mar (Mewin) y hacia el norponiente (cordillera de Nawelbuta). Se decidió por esta última y se dio comienzo a los preparativos de la caravana, estando lista se atravesó el río Quepe, el río Cautín y el río Cholchol, llegando a lo que es hoy el puente sobre el río Cholchol a un lugar llamado Rukapange, en donde el logko principal Nekulkeo decidió desplegar sus familias en los faldeos iniciales de la cordillera de Nawelbuta (tigre viejo) que en esos tiempos eran selvas vírgenes y así llegamos a esos territorios.

Mi padre Antonio Painecura Huircapán de 84 años de edad que vive actualmente en la ciudad de Santiago, relata así nuestra historia familiar:

"...De manera que a fin del año 1700 o a comienzo de 1800, al surponiente de Temuco, en las cercanías de Boroa, existió un lof denominado Kolweche, bajo el mando del logko Nekulkew y otros logko de menores rangos... el logko tenía tres esposas y nuestras raíces vienen del último matrimonio con la señora Mülleikew, los que tuvieron los hijos: Lincokew, Painecura, Marikew, Mülleikew, Llanquiray y Kinturay.

Hasta este lofche llegaron sacerdotes de la congregación Capuchinos en son de paz, solo querían conversar con los logko, para establecerse en el mismo lugar, lo cual fue aceptado, pasó el tiempo..., un buen día invitaron a una reunión a los padres de las familias mapuche y desde luego a los Jefes, expusieron sus pensamientos, querían construir una escuela, abierta a todos, sin discriminar edades, entregar conocimiento de lenguaje y distintas disciplinas desconocidas para mis ancestros, desde luego, tal propuesta fue aceptada con gran entusiasmo, dada la inteligencia y el afán de conocer, aprender y dominar todo conocimiento de mis gentes, no se debe olvidar que la historia indica una lucha de 300 años contra los españoles, lo que ratifica inteligencia, sagacidad, perseverancia y disciplina entre otras virtudes que, el combate realizado de generación en generación los hizo crecer en todo aspecto ya que el ser humano en contingencias de guerra desarrolla inequivocadamente. Además, cabe señalar que a la fecha nunca mi raza ha sido vencida o ha aceptado la rendición, por tanto tal propuesta les llenó de regocijo, a tal grado que participaron con ahínco en el proyecto que a su entender era de superación, en breve tiempo la escuela estuvo dispuesta, aulas adecuadas para las inclemencias del tiempo fueron ocupadas con gran interés por los alumnos, así transcurrió el primer año, según cuentan los antiguos..., y con gran éxito el segundo periodo escolar...

... En el transcurso del tercer año, el superior de los sacerdotes convocó a una reunión a los padres, incluidos los Jefes de cada familia, en ella señaló la gran posibilidad de enviar a varios jóvenes con todos los gastos pagados, al Seminario que ellos tenían en un lugar llamado Salamanca en España, a estudiar por tres años de modo que los weche wenxu (hombre joven) podrían llegar a ser sacerdotes y ser tan "sabios" como ellos, remarcando que: "obtendrán grandes conocimientos en el otro mundo". Conociendo, el hábil cura, el yo interno de tan valerosas personas, seres además de un genuino espíritu de coraje y audacia sembró vilmente en las mentes de un pueblo valeroso la semilla de una posibilidad de superación no esperada, sabía que tal 


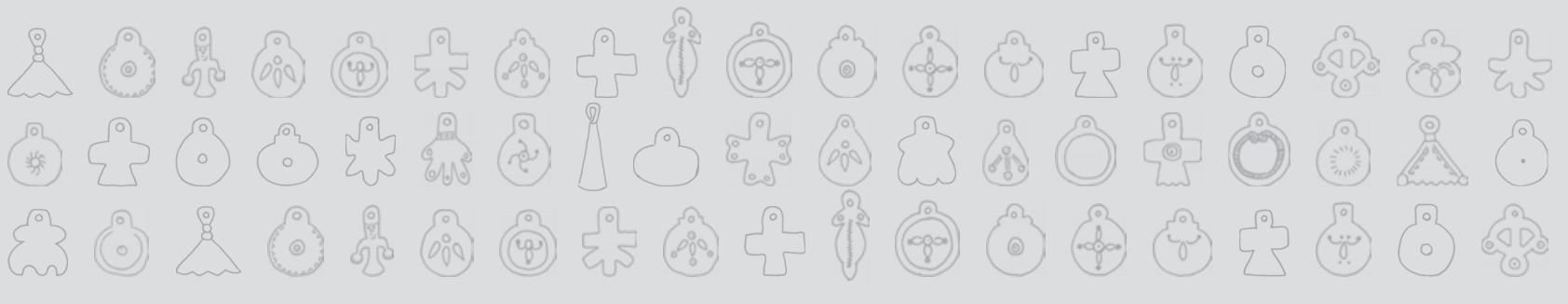

propuesta sería discutida pero dadas las características de los mapuche existía en su pensamiento analítico un alto porcentaje de ser aceptada, entonces el sacerdote les dio dos días para que analizaran y decidieran, dejando fijada la próxima reunión además de señalar que tenía ya la nómina de los niños seleccionados, como es de suponer, en esa lista estaban los seres con mayores y mejores características que satisfacían las intenciones ocultas de aquellos representantes de Dios en la tierra.

... Llegó el día señalado, en la reunión, los padres querían información fidedigna sobre el tiempo de permanencia en dicho país, el sacerdote dio el tiempo exacto, tres años y ocho meses, ante lo cual lo aceptaron y el religioso dio a conocer la lista de becados, el número de alumnos a la fecha no es clara, solo los mayores recuerdan que eran más de diez, así se preparó el viaje y la despedida que tanto para los padres como para los jóvenes les llenaba el espíritu de ilusión de pensar en todo el progreso que con el tiempo lograrían para las nuevas generaciones, así transcurrió el tiempo... Las actividades en el lofche continúan sin contratiempo, en normalidad se desarrollaban la relación entre los mapuches y los curas... hasta que se cumplió el tiempo y los alumnos no llegaron. El sacerdote director citó a una reunión y explicó que ese país quedaba muy lejos, al otro lado del mar, además el viaje era muy peligroso y solicitó un año más de plazo, lo que fue aceptado...

... Se cumplió el tiempo y los viajeros no dieron señales de vida. La autoridad sacerdotal solicitó en una nueva reunión un año más de plazo, los mapuches no le creyeron y se retiraron de la asamblea. Fue entonces que los logko se reunieron secretamente con el objetivo de tomar medidas en contra de los clérigos por semejante falta de respeto con la palabra empeñada, luego de debatir largamente, concluyeron en... jatacarles!... sorpresivamente... lo que realizaron con gran saña y dolor ya que comprendieron que dichos wigka sin ninguna consideración y con engaños les habían despojado de lo más preciado para ellos... jsus hijos!... La muerte les llegó, en castigo ante tal infamia, al tiempo que incendiaban las habitaciones que ellos mismos colaboraron en construir, uno o dos curas lograron huir cobardemente, buscando ayuda y justicia para ellos ique bajeza!... ellos sí eran seres dignos de respeto... Por aquel entonces los originarios de mi familia estaban organizados militarmente como es historia; si bien los combates se estaban desarrollando en el otro extremo de lo que hoy se conoce noreste de Concepción, luchas esporádicas ocurrían, por tanto las medidas de seguridad formaban parte de lo cotidiano, dentro de la logística, un papel de suma importancia era Güneytu Mapufe (espía: personas que lograban retratar la realidad geográfica, social, política, espiritual y militar de los territorios por donde probablemente pasarían o estarían las fuerzas militares enemigas, para esto se ubicaban en lugares estratégicos cumpliendo su misión con gran talento).

Un buen día apareció en el lof Kolweche, un Güneytu Mapufe en busca del logko Nekulkew para exponerle que andaban averiguando la ubicación del lof Kolweche (grupo de casa-amarillo desteñido), tales wigka informó andan con Xalkan Mamüj (fusil) (palo que truena), debido y comprendiendo que eran buscados por haber hecho justicia contra aquellos mafiosos de sotana, se trasladaron al poniente de Temuco, cruzaron el río Cautín, como destino escogieron un lugar denominado Ruca Pangue (casa de la leona), allí acamparon un corto tiempo para descansar y analizar la conveniencia de buscar un lugar que les diera mayor seguridad y cumpliera con los requisitos de alimentación, agua, clima entre otros, decidieron seguir el mismo rumbo, cruzaron el río Cholchol, así encontraron el terreno apropiado y le denominaron Kuwelche (cerro de gran altura), lógicamente este cerro les fue muy útil para observar al enemigo, en ese lof falleció el logko Nekulkew 


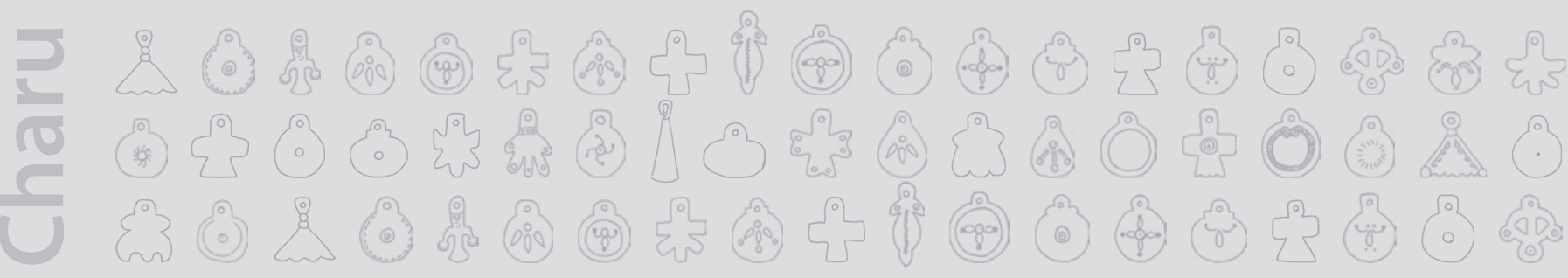

de avanzada edad, se ignora fecha. La historia de mi heroico pueblo indica que no podía estar acéfalo por mucho tiempo y fue escogido como sucesor el hijo mayor del fallecido de nombre Lincokew quien recibió el título de merced número 124 en el año 1889, tal documento señalaba que la tierra ocupada por los indígenas pertenecía al Estado chileno. Según consta en el Ministerio de Agricultura en el año 1979 el gobierno de aquel entonces modificó aquel título y promulgó la ley No 17.729 en la que se indica que la tierra era de propiedad de los mapuches, la que se mantiene vigente a la fecha.

Hoy por hoy aún existe el lof Kuwelche en donde mis familiares llevan una vida campesina y también disfrutan de los avances de la tecnología, lo que ha llevado a los jóvenes de mi pueblo a buscar el conocimiento, con el tiempo los Weychafe triunfaremos una vez más en esta vida. ¡RUMEL WEWAYIÑ! iTRIUNFAREMOS SIEMPRE!".

En su doctrina de evangelización, la iglesia cristiana católica implementó una serie de estrategias para evangelizar y civilizar según ellos a los pueblos originarios de nuestra América. Esta consistía en un proceso de educación en sus territorios para posteriormente seleccionar a aquellos niños que presentaran mejores condiciones para ser llevados a centros importantes como lo eran el Cuzco o a Quito para ser convertidos paulatinamente en curas y monjas, el objetivo era muy claro, que fueran a "evangelizar" a otros pueblos originarios de nuestra América.

Esto fue lo último que se supo de estos niños, fueron desarraigados cruelmente de sus familias por la congregación católica cristiana de los Capuchinos. Este mismo fenómeno lo sufrieron muchos pueblos y no cabe duda que hay una deuda histórica (ético-moral) de la iglesia cristiana católica para con nuestro pueblo. 


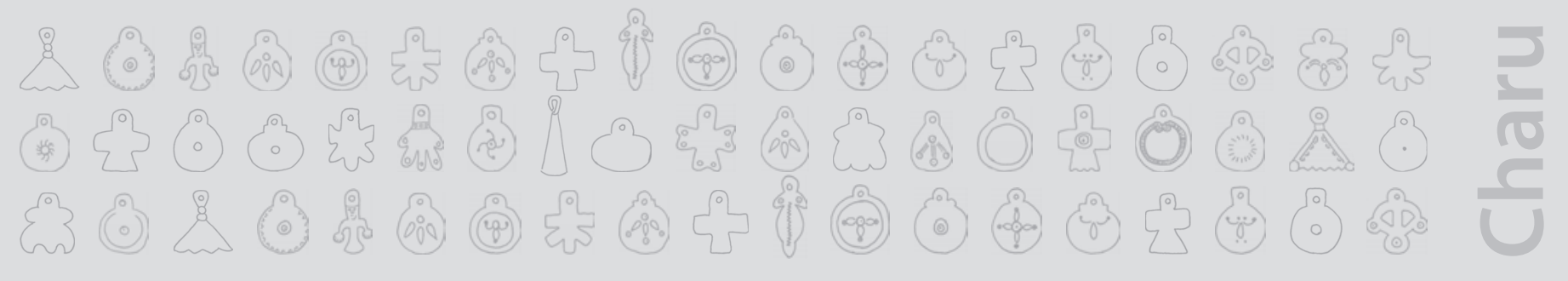

\section{Introducción al texto}

"Fey mew ka femgechi eleluwayiñ ta tüfa kom tüfachi rag, müleay tüfa mew, wente mapu mu müleay ta tüfa, ka femgechi elelkunuwayiñ ga müja, ka femgechi jemay wente mapu müleay, azno ga rumekagepalmün newen mew, ka newen mew rumekagepalmün, feyta nüafiymün tüfa, tüfa mu ta igkawaymün, feymew ta tüfachi rag, feychi zugu feychi kimün niealu ta tüfa igkawalu kiñepüle nentualu weshake newen, kake newen, fey mew küme mogen niaymün, feymew küme felen müleoy tüfa mew... pikunugeyiñ ga eja elkunugelu iñchiñ tüfa chi mapu mew, tüfachi mogen mew.

Welu, fenxen xipantu ta femfuyiñ, welu puwüy ga xipantu, wezwezüy ga che, fey mew ga, nüfiy tüfey chi rag, tüfey chi müja, fey mew ga fenzean ta tüfa, fey ta gülüafiñ ta tüfa, iñche ga zoy newengean ga, zoy nieli zoy newengean ga, zoy newengeay ta ñi newen, hotukaafiñ ka kakelu newen, pilu ga che, feymew ga ejkawüy ta tüfa, fey mu ga fey wüla ponuwi mapuluwüy ga rag, ponuwimapuluwüy ga müjo, fey mew ga ejkawüy ta tüfa" Ernesto Huenchulaf, 2011.

"Entonces también le dejaremos toda esta plata, eso estará aquí sobre la tierra, también le dejaremos el oro, también estará sobre la tierra, eso estará por si a ustedes le vengan a agredir con otras fuerzas, si viniesen con otras fuerzas, entonces cojan estos y con ello defiéndanse, por ello estas platas tendrán esas capacidades, esos conocimientos tendrán el de defender y hacer a un lado aquellas fuerzas dañinas, entonces podrán tener buena vida, un buen pasar, eso nos dijeron cuando nos dejaron en estas tierras, en esta vida.

Por muchos años así lo habíamos hecho, pero llegó el año en que nos transformamos y nos volvimos estúpidos, locos, toda la gente, entonces, cogieron aquellas fuerzas de la plata, aquellos oros, y la gente comenzó a abusar de ello, comercializarlo, 'lo moleré, tendré entonces más fuerza, al tener más, más fuerza tendré, entonces sobrepasaré a las otras fuerzas', al decir esto la gente, todos esos minerales se escondieron, se adentraron a las profundidades de la tierra la plata, el oro, entonces se escondieron definitivamente."

La Platería Mapuche es uno de los fenómenos más característicos del desarrollo de la sociedad mapuche y es expresión concreta de su filosofía en estrecha relación con la naturaleza. Y es al mismo tiempo afirmación de opulencia demostrativa de su riqueza económico-ganadera en la que juega el papel fundamental y determinante la mujer mapuche como la poseedora de la continuidad y de la fecundidad de la vida en un plano de igualdad en su küyehtun (ciclo menstrual) con la luna.

Las forma, graficaciones, incisiones, estampados y otros de la Platería Mapuche muestran la fineza y la maestría de sus cultores: el rüxafe, son estos que en un procesos de cambios y de espacios de tiempos van amalga- 


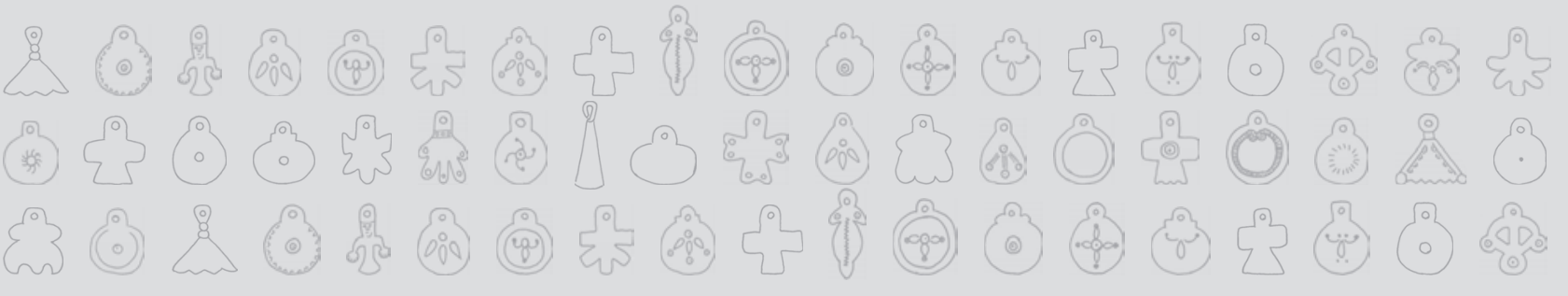

mando el conocimiento, la experiencia y la sabiduría del pueblo mapuche las que son expresadas en la construcción de joyas.

La Platería Mapuche es sin lugar a dudas la más acabada expresión de perfeccionamiento de la sociedad mapuche que reconoce que en ella hay una influencia del invasor español, pero al mismo tiempo hace desaparecer todo vestigio de estos para transformarse en una expresión propia y particular, que considera lo espiritual religioso así como lo económico, social y político de su funcionamiento de pueblo.

Nadie puede desconocer que la Platería Mapuche es el resultado de profundos cambios y perfeccionamiento de su organización y de su estructura de pueblo en su relación con el invasor español con el cual se convive en largos periodos de guerra y de paz, quedando al descubierto y con claridad que la Platería Mapuche comienza a desarrollarse e introducirse en nuestro territorio de norte a sur y es en la vida y práctica interna de los diferentes lofche, rewe y ayjarewe donde crece y se fortalece con fuerza y vitalidad. Trasciende la cordillera de los Andes en un intercambio económico-comercial y de alianzas familiares con los puwelche obteniendo con esto una poderosa base ganadera.

Lo intrincado y poco conocido del sistema de relaciones y la estructura social mapuche hacen que muchas veces o casi en la totalidad de los casos, los estudiosos del tema, chilenos y extranjeros, planteen o expongan hipótesis equivocadas o mañosamente manejadas para hacer creer que la Platería Mapuche es obra de la casualidad y no de su práctica espiritual, social y política permanente.

Las joyas mapuche expresan el conocimiento y pertenencia cosmológica en cuanto al origen de la vida en general y de la vida humana mapuche en particular, así como la relación entre la vida y la muerte y los diferentes momentos y espacios en que transitamos los mapuche por los mismos.

Las joyas mapuches expresan también la ubicación y roles de las mujeres en el funcionamiento de cada familia a la cual pertenecía esta connotación social y es al interior como al exterior de las familias en una construcción magistral de alianzas a través de los matrimonios.

Por último, y es lo más concluyente, la Platería Mapuche va buscando a través de su construcción su expresión política basándose en los diversos niveles que existían dentro de la sociedad mapuche y en la que jugaban un papel trascendental los logko y es en estos y en sus cabalgaduras donde termina de expresarse de forma elocuente y precisa la Platería Mapuche.

En los siguientes párrafos explicaré los fundamentos del origen de la platería y en ellos están contemplados los aspectos generales y particulares de nuestra identidad, de nuestra cultura como un todo único, armonioso y preciso, no dejando duda alguna de nuestra concepción de mundo, de pueblo y de familia en la cual estamos inmersos los mapuche.

El texto analizará dos grandes aspectos: primero abordaremos las causas que posibilitaron la aparición de la platería mapuche para lo cual analizaremos los diversos momentos históricos que nos ha tocado vivir por 


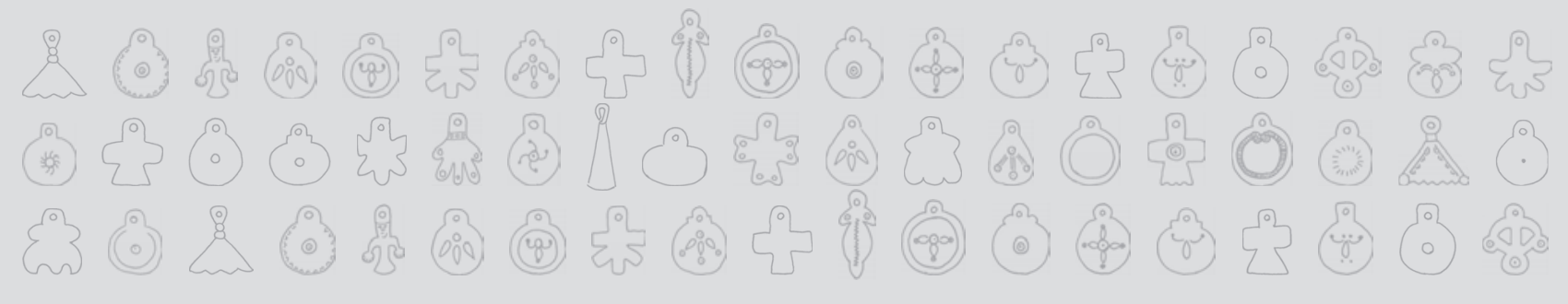

las distintas invasiones que nuestro pueblo y nuestro territorio han sufrido: la invasión del imperio Inca, la invasión del imperio español y la invasión y anexión de nuestro territorio por el Estado de Chile. Segundo analizaremos las diversas joyas mapuche de acuerdo a sus fundamentos, filosóficos, espirituales y religiosos, así como también el estudio de las joyas de acuerdo a la ubicación social de la mujer que la usa dentro de la familia y en la estratificación superior, también analizaremos el uso de las joyas según la expresión y reflejo político de quien las usa, específicamente las joyas usadas en los caballos y las joyas que particularmente que comenzaron a usar los logko. 



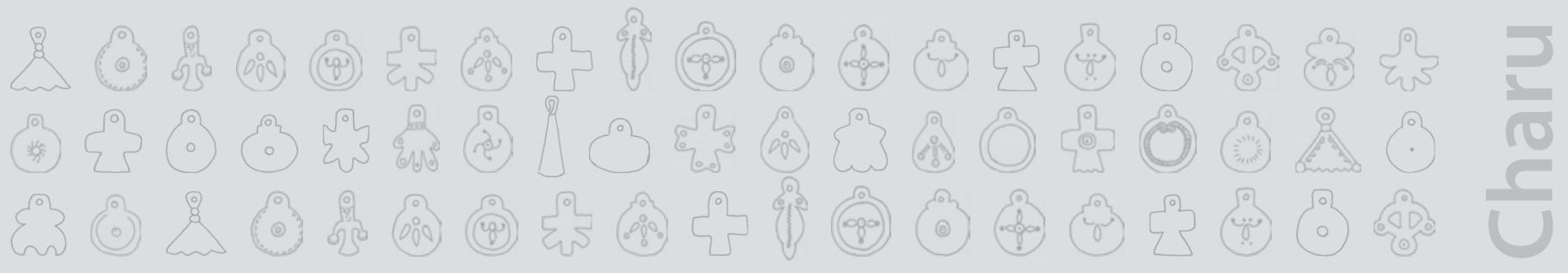

\section{PRIMERA PARTE}

\section{Fundamentos del origen de la Platería Mapuche}

"Antes los rüxafe eran elel, no cualquiera podía ser rüxafe, venía por herencia y todo eso. Ahora en este último tiempo, cualquiera que se haga un curso puede ser rüxafe". Ernesto Huenchulaf, 2011.

En el transcurso del desarrollo del hombre y de la humanidad siempre ha habido una característica que se ha hecho general para todos los pueblos, esta ha sido la de embellecer su cuerpo y su entorno para lo cual se han tomado en cuenta elementos de la naturaleza: vegetales o minerales que han sido la base más natural del inicio de la construcción de joyas.

El pueblo mapuche no ha estado ajeno a estas características, desde tiempos inmemoriales nuestros ancestros adornaban sus cuerpos con flores, plumas, caracoles de mar, piedras semipreciosas, pinturas vegetales y minerales. Todos estos elementos decorativos no eran simplemente por llevarlos o lucirlos, sino que obedecen a 'una' concepción de mundo y a los roles y funciones que tienen los mapuche dentro de este, así como su interrelación con todos los miembros de la naturaleza.

Nuestro pueblo desde su origen ocupó un territorio muy extenso de océano a océano, separado tan solo por la cordillera de los Andes, todo este territorio mapuche ya que poseíamos una sola concepción de vida, un solo lenguaje, una sola historia, los que quedan entre cordillera y el océano Atlántico es el Puwel Mapu y sus habitantes puwelche y desde la cordillera de los Andes al Pacífico el Gulu Mapu y sus habitantes los guluche: todos mapuche.

Las familias mapuche en estos inmensos territorios vivían de los alimentos que la naturaleza nos daba y la base fundamental era el lofche, no había sujeción entre los mismos y solo se elevaba este nivel social en el caso de grandes calamidades: guerras, enfermedades, sequías, inundaciones, terremotos. No poseíamos conocimientos de técnicas de recolección de metales y tampoco teníamos conocimientos de la rueda, sí desarrollábamos en muy pequeña escala alguna agricultura planificada y dábamos pasos importantes en la domesticación de algunos animales menores.

\section{INVASIONES DEL IMPERIO INCA}

Antes de la llegada del invasor español nuestro pueblo ya había sufrido otros intentos de dominación, específicamente la primera y segunda invasión inca a nuestro territorio, hechos acaecidos aproximadamente por el calendario cristiano occidental los años 1400 y 1450. El imperio inca ya estaba constituido en Estado. Los incas dominaban el arte de las ciencias, la economía y la metalurgia, construyendo utensilios domésticos agrícolas y militares. 


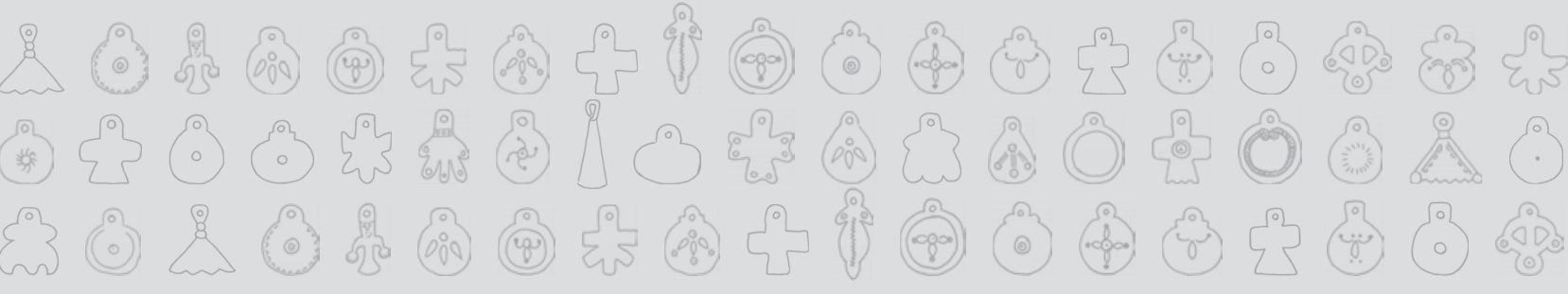

En su primera invasión (1400) el imperio inca llega con sus fuerzas militares hasta los valles del río Mapocho y del río Maule dominando al pueblo diaguita y a parte del pueblo mapuche como son los pirkumche, una vez definida la frontera sur del imperio los incas dan comienzo a la implementación de su doctrina de las tributaciones (pago de impuesto) de los pueblos dominados.

Con las fuerzas militares venía un representante del inca para esos territorios anexados denominado kuraka y un equipo para la administración política y económica, además de una innumerable cantidad de familias trasplantadas denominadas Miti imaes, que eran familias de distintas familias de pueblos dominados y de otra latitudes del imperio, que se caracterizaban por el dominio y conocimiento de diversas técnicas de producción o servicios y que eran llevados a esos nuevos territorios dominados con el objetivo de transmitir y enseñar sus conocimientos.

Sus fuerzas militares eran desplegadas en elevaciones predominantes en las cuales se construían fuertes militares que se denominaban pukaras, los pueblos dominados tenían la responsabilidad de la alimentación y del avituallamiento de estas fuerzas militares.

La doctrina de las tributaciones que los incas implementaban se caracterizaba por "cierta independencia" de los dominados a los cuales se les capacitaba para una mayor y mejor tributación ya sea en granos, animales, mujeres, las que eran llevadas a los centros políticos inca para que se casaran con funcionarios administrativos o militares y así tener una mejor dominación. En tanto, los hombres jóvenes eran llevados para la conformación de nuevas estructuras militares e ir a dominar a otros pueblos en otras direcciones del imperio y en metales preciosos (oro y plata) que eran obtenidos en placeres de distintos ríos de la zona central, el más conocido es el del estero de Margamarga y los ríos de Peñaflor y de Quillota.

El resultado del desarrollo científico tecnológico alcanzado por el imperio inca en el tema de la metalurgia es traspasado a las familias pirkumche, para obtención y purificación de estos metales podríamos decir sin tener duda alguna que esta es la PRIMERA BASE que fundamenta la futura aparición de la platería mapuche. Cabe hacer notar que ya a los incas y la gran mayoría de los pueblos que habían sido dominados usaban adornos metálicos de distinto tipo, no tan solo de plata y oro, sino también de cobre y de bronce, joyas y diseños que fueron traspasándose con el transcurrir del tiempo a la población mapuche fronteriza.

La segunda invasión inca el año 1450 y como resultado de sus campañas militares logran adentrarse en territorio mapuche y llegar hasta la ribera del río Maule (actual ciudad de Talca), en donde definen la frontera sur de su imperio.

Cabe hacer notar que los incas construyeron dos caminos que conectaban los pueblos dominados y sus centros políticos administrativos, uno fue construido por el valle central y el segundo por la costa del océano Pacifico y en su línea fronteriza construían en las elevaciones más prominentes sus fortalezas militares o Pukara.

Como resultado de esta segunda invasión se consolida la dirección sur del imperio inca generando dos fenómenos importantes como fueron la construcción de caminos y la planificación agrícola/ganadera de los 


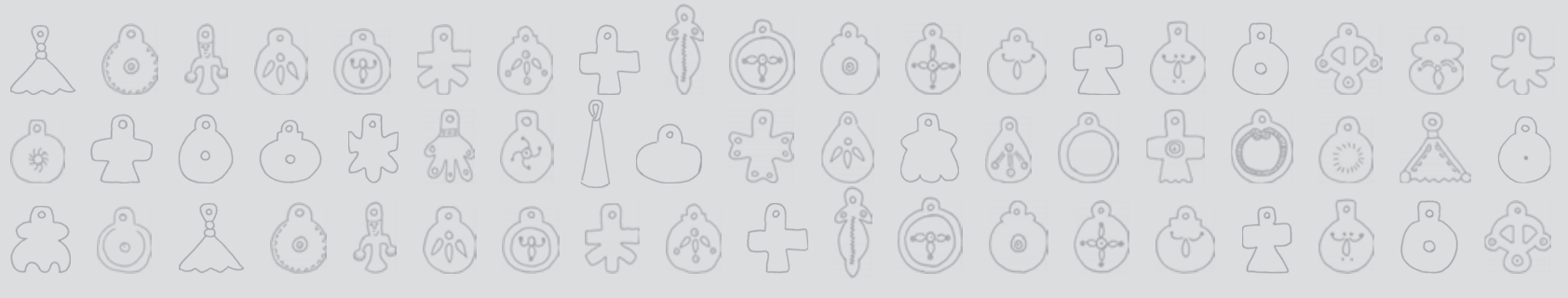

valles más fértiles, esto producía algunos cambios como eran la conformación de karas (villorrios) donde eran agrupadas las familias pirkumche con la respectiva construcción de casas hechas de madera y paja. Por otro lado se da comienzo a la domesticación de algunos animales como la llama y la alpaca, además se absorbe el conocimiento en la obtención y purificación de los metales.

\section{INVASIÓN DEL IMPERIO ESPAÑOL}

El imperio español había llegado a nuestro continente el año 1492 y demoró hasta el año 1541 para llegar hasta nuestro territorio, o sea 50 años, la invasión se hace sobre la base de los resultados de la guerra que era parte de su doctrina para su política de conquista.

El imperio inca nada pudo hacer frente al conquistador español y una vez controlado este, Pizarro y Almagro se dan al trabajo de los reconocimiento de las fronteras del imperio, el primer intento que realizan es en el año 1530, aproximadamente, en la dirección sur, con Diego de Almagro a la cabeza el que después de varios meses llega hasta el valle del Aconcagua y desarrolla un reconocimiento de toda la zona, el resultado aparente del mismo es que es un territorio pobre en metales preciosos y decide regresar al Cuzco para enfrascarse en una guerra con Francisco de Pizarro por el control del poder colonial.

Para entender la nueva doctrina que los conquistadores españoles implementarían en nuestro territorio debemos analizar lo siguiente:

A su regreso a España en su primer viaje Cristóbal Colón llevó a personas de los pueblos del Caribe a Europa, para mostrárselos a los reyes católicos para que fueran ellos los que definieran quiénes eran estos seres, que hablaban un idioma que no entendían, que comían productos desconocidos, que se vestían de una manera diferente, que tenían una religiosidad que no entendían, etc. Los reyes no supieron definir quiénes eran estos seres por lo cual decidieron enviárselos al Papa en Roma y que fuera él el que hiciera estas precisiones. El Papa y sus asesores después de meses de análisis llegaron a la conclusión que estos seres estaban en una etapa intermedia entre el animal y el ser humano, que por lo tanto no tenían alma o espíritu y por consiguiente la relación entre estos bárbaros y los conquistadores europeos debía ser la esclavitud como época ya pasada de los habitantes en Europa.

Pedro de Valdivia llega a la frontera sur del imperio inca el 12 de febrero de 1541 y se asienta en el valle del Mapocho y toma posesión en nombre de su rey del territorio y de sus habitantes. Cabe hacer notar que los españoles encuentran en casi todos los valles del Aconcagua al sur grandes plantaciones de productos agrícolas: zawe (quinoa), üwa (maíz), zegüj (frijoles) de distinto tipo, calabazas y grandes plantaciones de xapi (chile, ají), esta ultima como elemento central para la condimentación de carnes que eran secadas y posteriormente enviadas hacia el norte. Toman posesión de los pukaras que había en todo el territorio y desarrollan un plan de exploración de la línea fronteriza y de los posibles yacimientos de metales preciosos que podría haber en la zona.

En los primeros años de invasión española descubren müja (oro) de antiguos lavaderos explotados por los incas en el estero de Margamarga, en el río Quillota y en el río Peñaflor dando comienzo a su doctrina esclavista, 


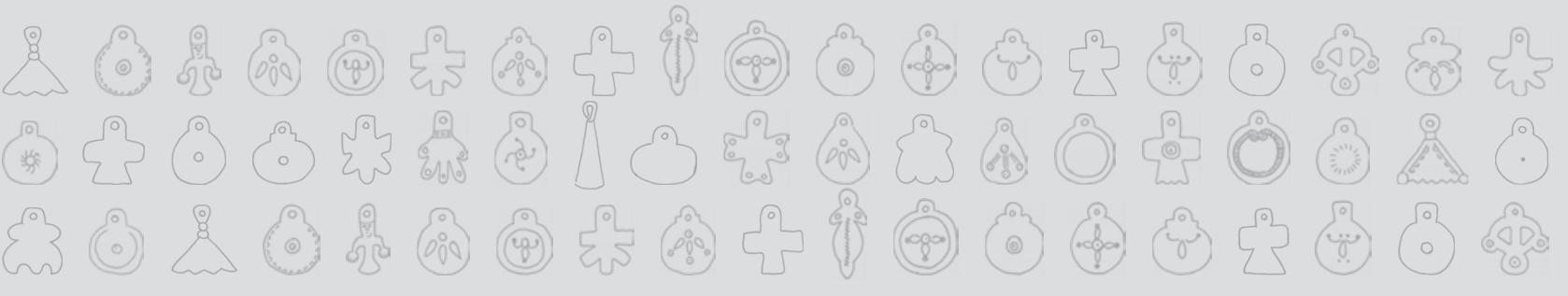

para esto se esclavizó a una cantidad de jóvenes varones para trabajar en estos yacimientos, podemos decir con certeza: la esclavitud también es base para la aparición posterior de la platería mapuche ya que a través de esta conocimos de las cadenas de hierro, de la pala, de los chuzos, de las picotas y por supuesto aprendimos a conocer la milla (oro). Cuando hablamos de los grandes levantamientos mapuche bajo el mando de Michimalongo y el posterior ataque y destrucción de la naciente ciudad de Santiago, debemos decir que esta tiene su base en el trabajo esclavo de los lavaderos.

Pedro de Valdivia una vez asentado en la frontera sur del imperio inca no destruye el sistema inca de las tributaciones, sino lo asume como propio, en su beneficio, y sobre este impone la doctrina esclavista, ahí aparecen dos elementos importantes uno de estos es el de controlar o realizar acciones militares con ejércitos que no son propios, uniendo dos conceptos Inca y Mapuche. Los Incas exigían que se les tributara con jóvenes varones para prepararlos militarmente y formar ejércitos que acompañaran o fueran auxiliares de las tropas españolas, estos fueron denominados Yana-Konas, el concepto Yana que está dentro de la estructura de la sociedad inca, aimara en particular, son personas que están determinadas desde que nacen hasta que mueren para el trabajo doméstico o de servicio, nacen y mueren siendo Yana.

Existe un pueblo al sur del actual estado de Colombia que se denominan Yanacona que al parecer fueron usados en los tiempos de la conquista española como indios auxiliares en los desplazamientos del ejército español.

Desde el mapuzugun, el término yaha significa una persona que no siente hambre, frío o calor, es una persona endurecida.

Koha que es un concepto mapuche aplicado dentro de su sociedad que tiene como objetivo y misión el ser mandado por sus logko. Son a estas personas las que se denominan yahakona y que probablemente eran indígenas de diferentes pueblos al que los españoles iban sometiendo y usando como carne de cañón en sus batallas frente a los otros pueblos que guerreaban.

Los españoles, al darse cuenta en sus primeras escaramuzas bélicas atravesando la línea fronteriza del río Maule, se dieron cuenta que era poco factible tener éxito militar con sus pequeñas fuerzas para adentrarse en territorio mapuche y conquistarlo para lo cual era necesaria la generación de esta fuerza militar auxiliar: yana-konas.

Para lograr la conformación de estas fuerzas auxiliares militares los españoles se vieron forzados a transmitirles conocimientos en la táctica y en la estrategia para poder actuar con ellos, además entregarles ciertos avituallamientos como son caballos y armamento menor. La doctrina aplicada para el empleo de estas fuerzas externas por parte de los españoles eran como fuerzas auxiliares y su misión la obtención de botines de diverso tipos: esclavos para los españoles, ganados, metales preciosos, granos.

Los españoles una vez que creen tener preparadas sus tropas para avanzar sobre territorio mapuche dan comienzo a su campaña militar, su avance llega hasta el río Laja y de ahí se dirigen hacia la desembocadura del río Biobío en donde encuentran una cantidad importante de lof che a lo largo de la costa. 


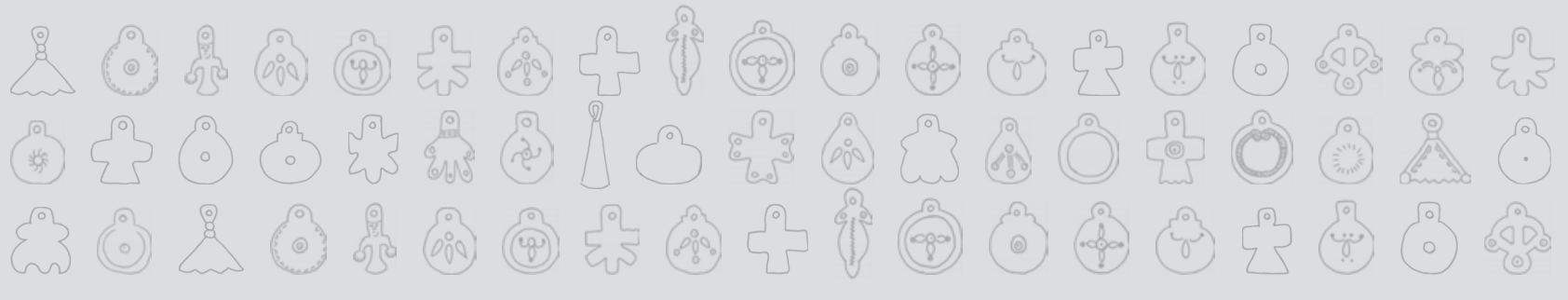

Valdivia se asienta en el lugar de Pegko (atado de hongos. O forma en que agrupan ciertas especies), en donde construye su fuerte militar y su ciudadela, dándose a la tarea de explorar el territorio con el objetivo de encontrar yacimientos auríferos los que finalmente encuentra en los ríos de Weken (lugar en donde se cazan los weke: auquénido nativo), Rere (pájaro carpintero) y Kilakoya, dando comienzo de inmediato a la aplicación de su doctrina esclavista tomando a los jóvenes mapuche como mano de obra esclava para esos yacimientos.

Las grandes rebeliones así como sublevaciones tienen como base el trabajo esclavo en los lavaderos y posteriormente los copamientos, destrucciones de fuertes y ciudades dentro de territorio mapuche y la expulsión de estos.

Por otro lado, los españoles implementaron un trabajo esclavo agrario camuflado como las políticas de encomiendas que no eran más que la entrega a sus capitanes de grandes extensiones de terreno con los lofche incluidos para el trabajo agrario esclavo.

Cuando hablamos de la invasión española a nuestro territorio por lo general solo nos referimos a las campañas militares y de los resultados de las mismas, pero estas eran solo el comienzo del proceso de invasión ya que detrás de las fuerzas militares venían los equipos político-administrativos, los campesinos, los comerciantes, pero además llegaban animales que no conocíamos como por ejemplo: caballos, vacunos, lanares, cerdos, aves de corral, trigo, avena, la rueda, carretas, arados, géneros, vidrios, diversas herramientas y utensilios, trataban de reproducir rápidamente todas y cada una de las funciones y tareas que se desarroIlaban en Europa.

\section{PROFUNDOS CAMBIOS EN EL PUEBLO MAPUCHE}

Si ya con la invasión inca nuestro pueblo había sufrido ciertos cambios en cuanto a su perfeccionamiento económico, social, político y militar esta aumenta considerablemente con la intromisión del invasor español.

Producto de las etapas de la guerra y de paz, sin embargo, nuestras estructuras sociales se fueron ampliando, fortaleciendo la unidad básica y permanente que era el lofche, durante el cambio se tuvo que unir varios lofche y conformar un nuevo nivel organizativo, social permanente que fue el rewe. Estos cambios en la sociedad mapuche obedecen a la necesidad de enfrentar la guerra por un lado y por otro garantizar la alimentación de las familias por lo que se hacía imperioso adaptarse a las nuevas condiciones.

La guerra nos obliga a introducir nuevas tácticas y nuevas estrategias, a modernizar nuestros ejércitos, los copamientos, destrucciones y expulsión de los españoles de nuestros territorios nos permitió conocer armas, utensilios, herramientas de metal como son: corazas, cascos, espadas, cuchillos, espuelas, estribos, lavatorios, jarras, vasos, cucharas, tenedores, ruedas, azadones, palas, picotas, arados por nombrar algunos. Todos estos elementos fueron introducidos en la vida cotidiana de la sociedad mapuche y los hicimos propios. 


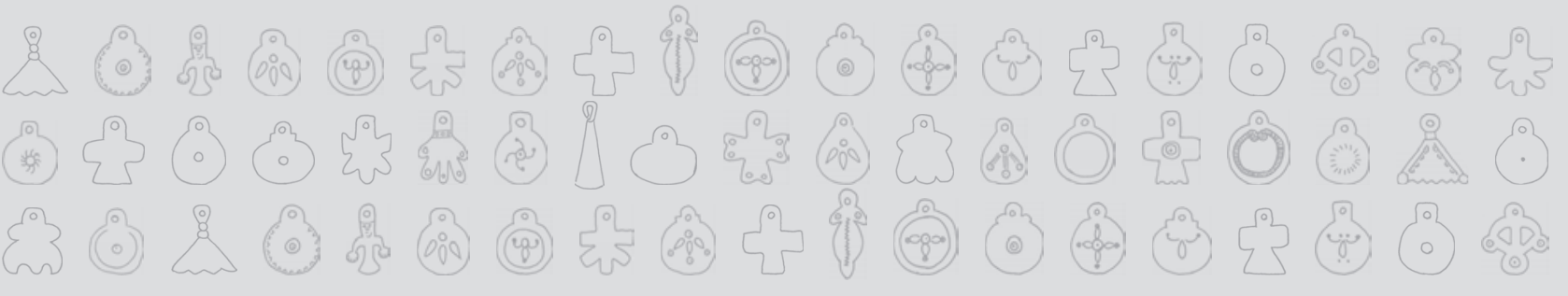

Nuestros asaltos a las diferentes encomiendas que los españoles implementaban en nuestros territorio nos permitió apropiarnos de los caballos, vacunos, lanares, cerdos, aparte de liberar a las familias que estaban en diferentes trabajos esclavos, dentro de ellos las herrerías y diversos talleres para la confección de herramientas, utensilios agrícolas y de casa, así como la fabricación de toneles y barriles. No hay dudas que este conocimiento de técnicas de la metalurgia es también base para la futura aparición de la Platería Mapuche.

El trabajo de mayor extensión agrario esclavo que los mapuche tenían en las encomiendas nos acercó al conocimiento de la agricultura, de esta manera se introdujo la producción de trigo, avena, centeno, lo que nos permitió dar aseguramientos a nuestras tropas. Se organiza la producción de granos, de tal forma de garantizar la alimentación teniendo algunos plantíos en la espesura de la montaña en donde los españoles no se aventuraban a avanzar, lo mismo ocurrió con el almacenamientos de los granos de forma escalonada y con métodos naturales de conservación.

La introducción de los animales traídos por los españoles determinó cambios en nuestra economía, la que paulatinamente se fue transformando en una economía ganadera, la que a su vez aceleró y fortaleció la estructura de los rewe al interior de la sociedad mapuche, como un nivel permanente y con una socialización cada vez más particular de las funciones, roles y responsabilidades. De esta manera se da comienzo estratificación de la sociedad mapuche.

El caballo tiene particular importancia en estos cambios, dado que permitió aumentar considerablemente la velocidad de un punto a otro, lo que produjo cambios en nuestra estrategia militar, específicamente en la concentración y desconcentración de nuestras fuerzas militares. Todo esto ponía en tensión a muchos rewe aumentando considerablemente el Teatro de Operaciones Militares.

El enjaezamiento que realizaban los españoles de sus caballos para la guerra y para actividades sociales va a tener influencia futura para la construcción de la platería de los caballos de los logko, por lo tanto el caballo es base importante para la aparición futura de la platería mapuche.

Como resultado de la guerra, se dieron muchos casos de prisioneros españoles los que para salvar sus vidas entregaban conocimiento y técnicas de la metalurgia, inicialmente para la construcción de herramientas y utensilios y posteriormente conocimiento para la construcción de joyas. Algunos de ellos formaron familias al interior de las estructuras de la sociedad mapuche.

El desarrollo de la guerra en los primeros cien años, 1541-1641, cambia el escenario inicial, ya que como resultado de esta, los españoles fueron obligados a parlamentar y reconocer frontera, soberanía e independencia al pueblo mapuche.

En el Parlamento de Quillín el año 1641, las autoridades españolas y mapuche acordaron que la frontera fuera el río Biobío, también se definieron los puntos de comercialización de productos, los valores de estos acordándose que el mecanismo para la compra y venta fuera el trueque. Se hizo entrega de ambos lados de los 


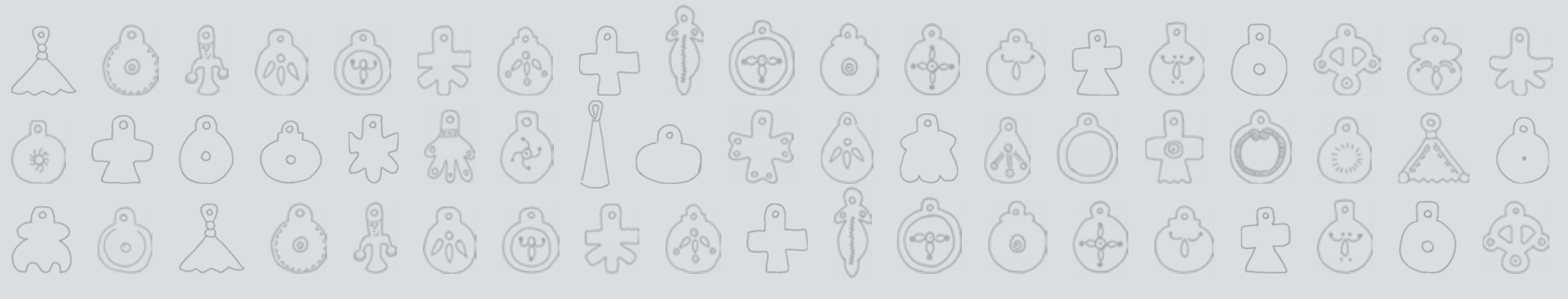

prisioneros respectivos, se acordó el ingreso de algunos comerciantes y curas para la conformación de escuelas e iglesias, estos fueron los convenios más importantes del parlamento, entre otros.

A partir de este parlamento, el escenario dentro del pueblo mapuche quedó estabilizado y fortalecido a partir de los siguientes cambios:

1. Fortalecimiento y predominio de la ganadería como base fundamental de la economía mapuche, cuestión que se proyecta hasta el año 1881.

2. Definición de una política económica que tiene como base la comercialización del ganado con los españoles en los diversos puntos de comercialización que se acordaron y los valores de los productos. Este aspecto es importante para la aparición posterior de la platería mapuche dado que las cantidades de productos a comercializar puso en jaque el sistema de trueque y los españoles crearon en el Cuzco una Casa de Monedas para abastecer a las capitanías generales de Santiago de nuevo extremo y de Buenos Aires.

El metal que se utilizó para la construcción de las monedas fue la plata que era extraída fundamentalmente de las minas de Potosí.

La moneda de plata obtenida por los mapuche en los intercambios económicos comerciales con los españoles es una de las bases fundamentales para la aparición futura de la platería mapuche.

Cabe destacar que producto de la comercialización de ganado, los mapuche van seleccionando los vacunos para la venta, los que reciben el nombre de kujiñ, el que posteriormente derivó en el sinónimo de dinero.

El desarrollo y fortalecimiento de la economía ganadera determina también su expansión hacia el Puwel Mapu, en donde los puwelches controlaban una gran masa ganadera en la inmensidad de la pampa, pero sin tener puntos de comercialización formalizados con los españoles, lo cual determinaba un fuerte intercambio económico comercial de ganado entre puwelche y guluche en ambos lados de la cordillera, para luego este ganado ser vendidos en los puntos de comercialización en las riberas del río Biobío por los guluche. Lo más característico en esta etapa es el comienzo de las alianzas por matrimonios para fortalecer los poderes económicos y los político-militares de los lofche y rewe en ambos lados de la cordillera.

3. Fortalecimiento de las estructuras sociales y políticas de la sociedad mapuche: sin lugar a dudas es que el resultado exitoso de la economía ganadera por un lado y la necesidad de dar respuesta a las etapas de guerra por otro, determinó que la sociedad mapuche debía organizarse de manera diferente, sobrepasando el nivel del lof che, para lo cual debía agrupar varios lof che bajo una sola dirección económica, social y política, de carácter permanente que se denominó rewe y que a finales de 1700 se transformaría en un nivel superior denominado ayjarewe. 


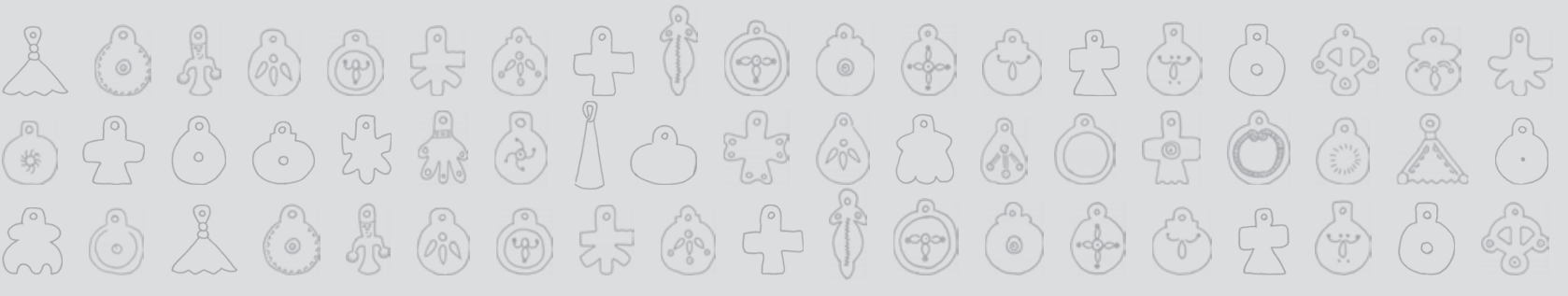

El conocimiento de las relaciones internas y externas de cada uno de los niveles sociales de la sociedad mapuche es fundamental para determinar el uso, función y nivel de la Platería Mapuche.

Toda la acumulación de conocimiento de la metalurgia obtenida desde los españoles, así como el dominio de la filosofía, de la espiritualidad y de la religiosidad mapuche, unido al conocimiento de las estructuras sociales y políticas, tiene como resultado casi de una forma natural la aparición del rüxafe, el cual es incorporado dentro de las estructuras de la sociedad mapuche con funciones específicas a desarrollar: el de construir joyas mapuche sobre las bases ya descritas.

Rüxafe: Palabra compuesta: el que maneja objetos metálicos

Rüxan: verbo que se refiere al acto de pulir, limpiar, modelar finamente. El sufijo ' $f e$ ' se refiere a la persona que tiene por oficio ese verbo. Este término es importante de profundizar ya que desde la filosofía mapuche se analoga al acto de pulir personas, espíritus, corazones. Es decir, constituye también un acto de formación y construcción de persona, che.

El rol y función del rüxafe dentro de las estructuras de la sociedad mapuche viene por herencia familiar consanguínea y su preparación en el conocimiento de este arte comienza desde corta edad, el que durará hasta cuando aprenda todas las técnicas de construcción y el manejo de la filosofía mapuche, las estructuras sociales y políticas a la cual él pertenezca.

El lieg (material plata), lo mismo que el rag (moneda de plata), es utilizado en la construcción de joyas dadas sus características de protección espiritual para las personas que las usa, existe una conexión entre las joyas de plata, la mujer mapuche y la luna. A finales de 1800, todo el siglo 20 y durante estos primeros 11 años del siglo 21 se comenzó a utilizar de forma paulatina por la mujer mapuche la müja (oro) en la construcción de chaway (aros).

El desarrollo de la economía ganadera y la comercialización de productos entre mapuche y españoles, deja en manos mapuche una gran cantidad de monedas de plata que es la base material para la posterior construcción de las joyas mapuche, el que se incrementa y se fortalece con el intercambio económico comercial entre puwelche y guluche.

Este nuevo escenario determina que se expresen con nitidez: el conocimiento de la metalurgia, el material para la construcción de joyas, pero por otro lado la necesidad de que alguien construya las joyas, que posea el conocimiento de la filosofía, espiritualidad, religiosidad, de las relaciones internas y externas de los lofche, que conozca, maneje los códigos y normas de las expresiones políticas dentro de la sociedad mapuche.

Así es como aparece el rüxafe como la amalgama de todos estos factores, se ubica dentro de las estructuras sociales, cumple un rol y una función, para a través de las joyas construidas, expresar belleza. 


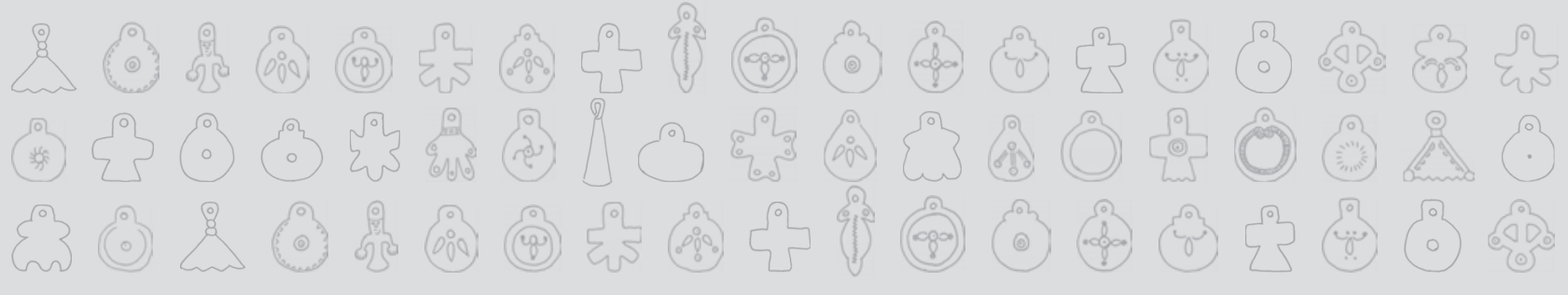

\section{EL ESPLENDOR DE LA PLATERÍA MAPUCHE}

"...y como mujer nosotras de alguna manera estamos echando adelante un poco los símbolos nuestros, el imaginario nuestro como mujer y que dentro de ese imaginario y dentro de ese destacar a la mujer dentro de esta urbanidad o dentro de los rituales donde tú te desenvuelves, es poder representar o representarte a ti misma dentro de lo que eres como mapuche". Juana Paillalef; 2011.

El desarrollo de la economía ganadera, el fortalecimiento de las estructuras sociales, el perfeccionamiento de las expresiones políticas en el inmenso territorio mapuche, potencializa el auge y esplendor de la platería mapuche.

En los siglos 18 y 19 se determinan con mejor precisión los distintos Füta El Mapu (identidades territoriales) en el Gulu Mapu: Bafkehche, Wenteche, Naüqche, Pewenche y Wijiche, cada una de ellas con sus propias características en cuanto a las construcciones de sus joyas.

El desarrollo y consolidación de la sociedad mapuche tiene como resultado la definición de las diversas estructuras y jerarquización en su interior, por otro lado define y determina los diversos roles y funciones de cada uno de sus miembros. Este aspecto es fundamental para entender el gran despliegue de creatividad de los rüxafe para tomar las ideas principalmente de los logko a la hora de crear las joyas que en esencia deben dominar el conocimiento de tuwün de la persona, del küpalme de la familia a la cual pertenece y el conocimiento de antiguas graficaciones que se fueron traspasando de generación en generación, de esta manera se van dando formas a diversidad de joyas.

El saber la composición de los mapuche reyñma (familias mapuche): lofche, es fundamental para entender las joyas dentro de la familia, a saber de las ciencias sociales era una familia consanguínea patrilineal, para nosotros los mapuche un lofche una familia ampliada por la sangre del hombre y de construcción generacional, es decir, esta la línea generacional del logko, sus hermanos y sus primos, con sus mujeres, hacia adelante pueden estar la línea generacional de sus hijos, de sus sobrinos y sus mujeres, más adelante puede estar la línea generacional de sus nietos, la de sus sobrino, nietos y sus mujeres. Hacia atrás está la línea generacional del padre del logko, sus tíos y las mujeres de estos, más atrás está la línea generacional del abuelo del logko, los tíos abuelos del logko y sus respectivas mujeres. Es preciso destacar que cuando una mujer mapuche dentro de esta estructura se casaba, se iba a vivir a la familia de su marido y llevaba su tuwün el cual se integraba a la familia que se unía y esto era determinante a la hora de construir las joyas y las graficaciones que estas tenían.

En este sentido, el rüxafe cumple una función artística de orden colectiva que consiste en plasmar los diseños de cada reyñma (familia), de cada lof mapu (espacio territorial). La gran diversidad de diseños se debe en gran medida a que también cada logko pedía un diseño propio, cada gizol lo suyo y los machi otros tanto. Muchos de estos diseños responden a los pewma (sueños), a los rakizuam (pensamiento, construcción) de los reyñma que buscan trascender y mostrar sus ascendencias, territorios y origen en una pieza de platería. 


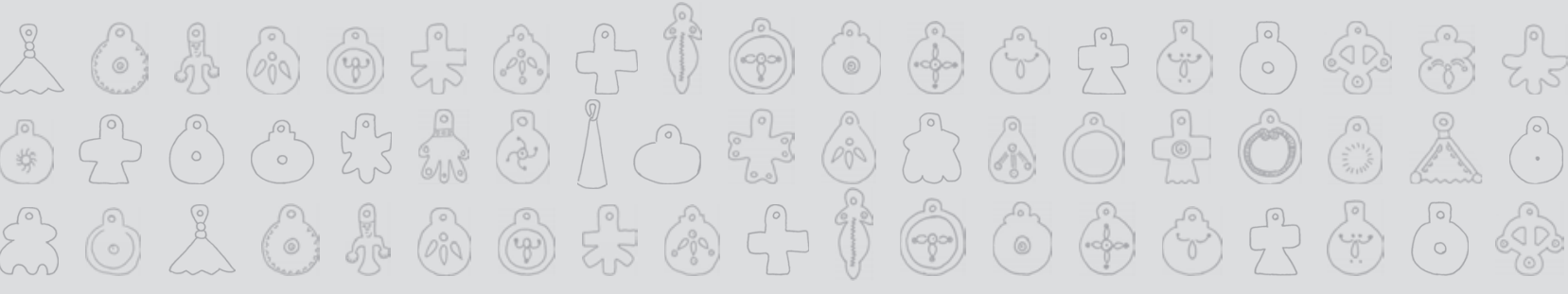

El matrimonio mapuche es otro elemento destacado dentro de la platería, en el transcurso del tiempo los matrimonios fueron la base fundamental de la política de alianzas que implementaban los logko con el objetivo de fortalecer el poder político lo que determinaba el control territorial y dentro de este el control de los pastos, de las aguas y de distintas vías comerciales para el desarrollo de la economía ganadera. Un ejemplo de esta situación era la conformación de la familia del logko Colipí en la zona de Purén el que llegó a tener 23 esposas.

El matrimonio era por tanto el mecanismo justo para ampliar las familias y fortalecer el trasiego económico comercial hacia los puntos de comercialización en las riberas del río Biobío y para asegurar los pasos cordilleranos en sus viajes de comercio y guerra hacia el Puwel Mapu.

Este gran dinamismo y entrelazos de la sociedad mapuche a través del matrimonio determina desde el punto de vista de la platería mapuche una gran creación de joyas de todo tipo y que define al interior de los lofche que existan dos o tres rüxafe para satisfacer los distintos pedidos de joyas de la mujer mapuche que considera obviamente sus tuwün para la construcción, es por tanto el matrimonio una de las bases fundamentales para las distintas creaciones en las joyas mapuche.

Las corrientes y modas al interior del pueblo mapuche son aspectos poco analizados en la platería es como que estas no existieran o no se hubiesen dado, cuestión que es inexacta. Como en todo pueblo, los mapuche a través de sus actividades multifacéticas, en la cual el movimiento de un lugar a otro de nuestro territorio juega un papel de primer orden, fueron conociendo variadas creaciones y que se fueron replicando o usando de manera permanente, ejemplo de esto son los cabezales y riendas de los caballos en que la influencia de la Platería Puwelche juega un papel de primer orden, lo mismo ocurre con el uso de cuchillos y dagas que en su gran mayoría fueron construidos en el Puwel Mapu y replicados en el Gulu Mapu y de gran uso por los logko y sus cabalgaduras. En la dirección contraria también ocurrió el mismo fenómeno, gran cantidad de joyas de distinto tipo fueron llevadas al Puwel Mapu fundamentalmente chaway, xariküwü, xarihamuh, keltachapewe y rüxil.

La gran construcción de joyas de todo tipo fue generando modas dentro de la sociedad mapuche, algunas de ellas han permanecido en el tiempo, en particular aquellas que tienen una base filosófica espiritual como son los keltatuwe, xarilogko, süküj, entre otros. Todas estas joyas se mantuvieron en el tiempo hasta el día de hoy y fueron tomando formas y graficaciones diferentes de acuerdo al Füta El Mapu (identidad territorial) a la cual pertenecen.

Las modas en la Platería Mapuche tuvieron su máximo desarrollo en las joyas que tienen una base social y política para su construcción ya que las normas para su construcción no son tan estrictas, salvo las definiciones gráficas de las mismas que están determinadas por el tuwün y que pueden estar expresadas por estampados, cincelados, repujados, globulados, burilados. Lo particular de las modas está determinado por la mantención de las formas de algunas joyas y por la adopción de elementos particulares o característicos del Füta El Mapu (identidad territorial) lo que lo diferencia de otras. 


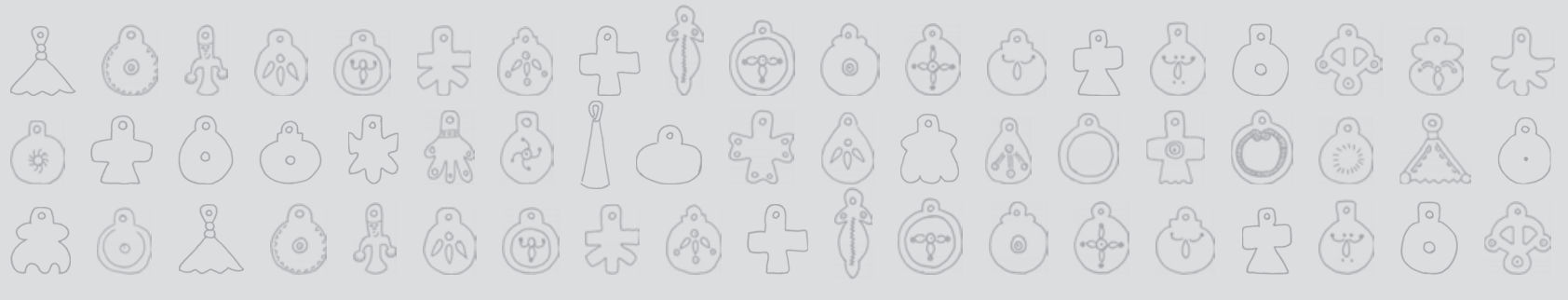

La aceptación por la mujer mapuche de las joyas que se iban construyendo determinó que estas se fueran quedando por largo tiempo y de algunas de ellas todavía las podemos disfrutar. Otras no tuvieron la misma aceptación, por esta razón fueron fundidas para ser construidas nuevamente en otras joyas tomando en cuenta otras formas, graficaciones y sobre la base de elementos del entorno en la cual se encontraban las familias.

La construcción de diversas joyas transformó las creaciones iniciales en un arte, ya que sus cultores, los rüxafe, atendieron los requerimientos de la mujer mapuche y del logko sobre la base del conocimiento filosófico espiritual, el movimiento entre la vida y la muerte, las formas espaciales del wajmapu, las relaciones intra y extra familiares, los elementos de su entorno, así como la geografía del territorio.

Los rüxafe definieron formas, usos y funciones de las joyas, las que armonizaron con elementos de la naturaleza, la belleza de los mismos las hicieron únicas. El diseño mapuche para la construcción de las joyas toma en cuenta también las bases filosóficas espirituales, la ubicación social, la expresión y el reflejo político son tomados en cuenta a la hora de desarrollar un diseño en las joyas mapuche. Es innegable que las técnicas del diseño están presentes en cada una de las joyas en particular y están presentes en las joyas en general.

\section{ANÁLISIS DEL DESARROLLO TÉCNICO DE LA PLATERÍA MAPUCHE}

Como ya hemos analizado, la acumulación del conocimiento técnico fue la base para lo que en el futuro sería la Platería Mapuche, comienza con las dos invasiones del Imperio Inca a nuestro territorio, este acercamiento se genera a partir de querer embellecer los cuerpos, lo que inicialmente se hacía con flores, plumas, conchas marinas, piedras semipreciosas, pinturas minerales y vegetales, además de algunos atuendos hechos con pieles de diversos animales: nawel, xapial, gürü, koz-koz, que los mapuche conocemos como mañawa.

Para entender lo vertiginoso que fue el desarrollo técnico de la platería mapuche, se debe analizar la situación del conocimiento de la metalurgia en el pueblo mapuche, a partir de 1400 en adelante y posteriormente a partir del año 1541.

En esos años el pueblo mapuche no tenía conocimiento de extracción de metales, tampoco de su purificación y menos de su utilización. Sin lugar a dudas que las dos invasiones incaicas y la invasión española a nuestros territorios contribuyeron enormemente al conocimiento y dominios de una serie de técnicas de metales, que posibilitó posteriormente la aparición de la platería mapuche.

En un principio el moldeo básico de cada una de las piezas fue a través de las técnicas del martillado, la que se hacía sobre monedas de distintos tamaños y grosores, las que posteriormente se les iba dando formas en sus contornos con cinceles sobre base de metal que podían ser los yunques, la posterior introducción de limas y de lijas determinó joyas de mejor calidad en cuanto a sus terminaciones, con el transcurso del tiempo a las joyas se le fueron agregando diferentes técnicas, tales como: estampados, burilados, globulaciones e incisiones lo que le dio a las diferentes joyas una marcada calidad en cuanto a su confección y en cuanto a su representación. 


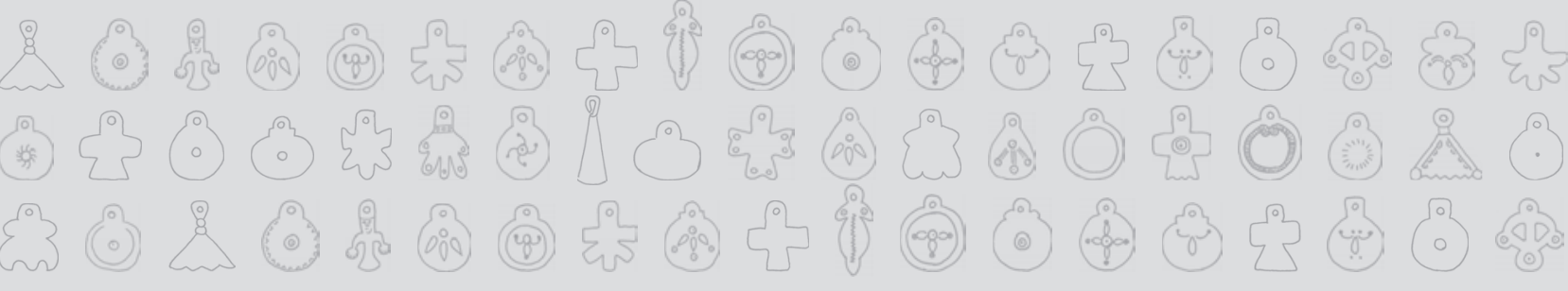

Un salto de calidad importantísimo en la platería mapuche fue cuando los rüxafe conocieron, dominaron e implementaron técnicas del fundido, en un inicio principalmente para lograr láminas de mayor grosor y mayor superficie, lo que les permitía poder construir joyas de mayor tamaño y mayor complejidad como son los keltatuwe, süküj, xapelakucha, rüxil, tupu y ponzones.

El fundido comenzaban con la colocación de monedas de plata de distintas dominaciones en un charu (crisol) a la cual se le aplicaba fuego hasta fundirlas y posteriormente verterlas sobre moldes de greda. Una vez obtenida la pieza era trabajada con diferentes técnicas para la obtención de la pieza final, la más recurrente técnica utilizada el del martillado con el objetivo de expandir la lámina, obtener un grosor adecuado y parejo para luego trabajarla. Inicialmente las técnicas del fundido tenían raíces básicas, las que en el transcurso del tiempo se fueron complejizando, pero a su vez aceleró el mejoramiento técnico de las láminas, se fueron introduciendo nuevos elementos para el fundido como fueron los fuelles (hechos con cuero de animales) lo que permitía disminuir considerablemente el tiempo del fundido, mejorando considerablemente su calidad.

La construcción de alambres de distintos grosores mejoró notablemente la calidad de las joyas mapuche ya que el armado de las distintas piezas lleva una gran cantidad de argollas y arandelas que se construyen con alambres. Otro aspecto a destacar en el fundido es que permitió obtener láminas, las que mediante moldes de fierro o de plomo posibilitaban construir tubos de distinto tipo, las que pasan a utilizarse en el armado de distintas joyas mapuche, esto sin lugar a dudas permite la realización de una gran cantidad de diseños, con la utilización de tubos que se mantienen hasta hoy, como son los Regi-Regi y otros.

El dominio de las técnicas del fundido posibilitó también la preparación de distintos tipos de soldaduras para la construcción de piezas de platería cada vez más complejas en su armado y en sus terminaciones, a partir de ahora las distintas piezas irán completamente soldadas en sus junturas, lo que les dará a las mismas una fineza en sus terminaciones. A partir de esos momentos se podrán observar relieves y sobrerrelieves a partir de piezas soldadas unas sobre otras.

Otro aspecto destacado en el desarrollo y fortalecimiento de la Platería Mapuche fue el aprendizaje y aplicación del moldaje de esferas y campanas a través de las técnicas de percusión (martillado) y la construcción de piezas como el punson y los chojol, esto enriqueció y diversificó enormemente la Platería Mapuche. En su etapa de mayor esplendor, esto se expresó en la construcción de escudillas, mates, bombillas, kaskawijas entre otros. Cabe destacar en esta etapa la utilización de boquillas de metal, especialmente de bronce para acelerar el proceso de aumento de la temperatura en las piezas a soldar a través de avivar el fuego con estas boquillas, había de distintos largos y grosores según sean los objetos a soldar.

A finales del siglo 18 (1700) y principios del siglo 19 (1800), el desarrollo y despliegue de la Platería Mapuche llegaba a su máximo esplendor haciendo uso de todas las técnicas conocidas y aplicadas, lo que permitía observar y deleitarse de contemplar una gran cantidad de piezas en todo el territorio mapuche, las que tenían finas terminaciones, diversos gravados que eran particulares según en el territorio que se construyeran. Es durante estos tiempos en que la Platería Mapuche logra definir con mayor claridad sus particularidades terri- 


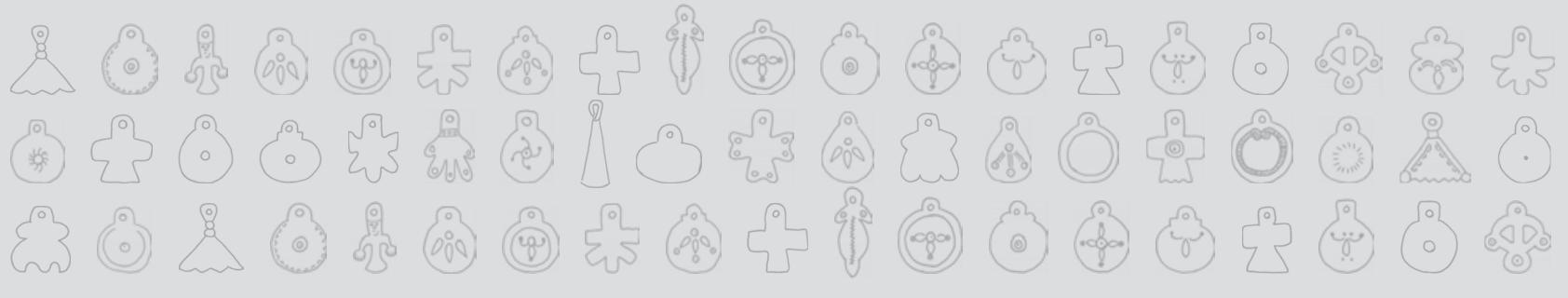

toriales y también las modas y corrientes que se van imponiendo o quedando en su interior de acuerdo a la aceptación de quienes iban a usar esas joyas.

Es en este tiempo en que llegan a los rüxafe técnicas más avanzadas de la fundición que comienzan a ser utilizadas en las joyas mapuche, como son el fundido en cera perdida y el fundido en moldes de greda (sistema de cajas) en el cual el estampado en la greda se hacía a través de matrices de metal o madera. La aplicación de esta técnica permitió la construcción de piezas con volúmenes y complicaciones importantes, lo más característico era la construcción de muchas piezas con un mismo molde, el resultados del o los procesos de fundición logró que la platería mapuche creara pün y püjü y los utilizara como colgantes de las placas inferiores de distintas piezas.

Los rüxafe con la acumulación de conocimientos, aplicación de nuevas y mejores técnicas pudieron construir piezas de mayor volumen, como eran los estribos, espuelas, rebenques y muchas de las partes del enjaezamiento de los caballos. Además, se dio comienzo a la construcción de piezas como adornos de los logko como son: grandes hebillas para sus cinturones, tachones especiales para el lucimiento de sus sombreros, empuñaduras de plata para sus cuchillos y vaina para los mismos.

Se dio comienzo también por parte de los rüxafe de la construcción de rostros humanos en un intento de darle forma a las fuerzas y energía generadoras de la vida (Elmapun, Elchen, Günemapun y Günechen), las que fueron soldadas a diversas piezas de la Platería Mapuche como son: keltatuwe, xapelakucha, süküj, rüxil, yüwüb küwü (anillo) y chaway, hasta el día de hoy podemos ver estas figuras las que le dan mucha fuerza o energías a estas piezas y por supuestos a quien las usa.

En esta etapa comienzan a aparecer otros utensilios y joyas enmarcadas dentro de la platería mapuche poco conocidas, como son las kixas de plata o de otros metales (bronce o cobre) o una combinación de estos, en la que se consideran otros elementos no metálicos como la madera y la greda. En el Puwel Mapu se comienzan a crear kojog (máscara de plata o de madera) de láminas de plata de grandes proporciones para las actividades ceremoniales y/o sociales. Lo mismo ocurre con piezas de platería que eran de las joyas de uso de la mujer mapuche y que paulatinamente comienzan a ser traspasadas al enjaezado de los caballos.

Muy característico también de las primeras décadas de 1800 es el uso de monedas dentro de la construcción de las joyas mapuche como ser en los xarilogko, keltachapewe, xarihamuh, xariküwü y en los yüwüb küwü (anillos), en estas piezas las monedas son como el cuerpo de las mismas y podían tener como colgantes otras monedas más pequeñas u otros colgantes de diversas formas. La utilización de las monedas como tales fue de un gran uso en una cantidad importante de joyas mapuche.

\section{FUNDAMENTOS DE LA DECADENCIA DE LA PLATERÍA MAPUCHE}

A principios de 1800, las colonias españolas en tierras de América se debilitan por la invasión de Napoleón a Europa y se crean condiciones para que los criollos nacionales desarrollen su guerra por la independencia y se vayan conformando los futuros Estados nacionales. 


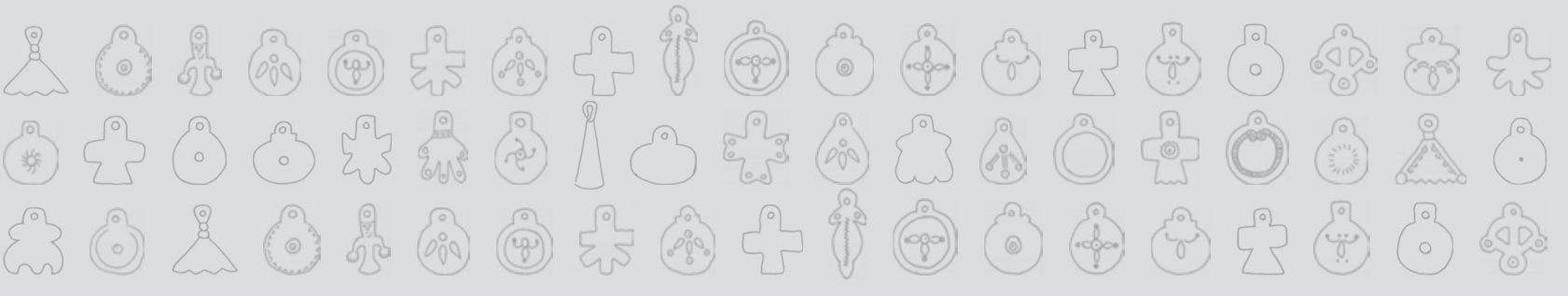

En Chile el Estado se conforma en 1818, teniendo como frontera norte los valles de Copiapó y por el sur el río Biobío, con el naciente también Estado de Argentina tenía como frontera las elevaciones de la cordillera de los Andes y por el poniente el océano Pacífico.

Una de las primeras tareas que se da el Estado de Chile dentro de su doctrina es determinar sus fronteras estatales y define dentro de su cuerpo de leyes que el territorio mapuche también les pertenecía y que todos los habitantes de "sus territorios" "eran chilenos", cuestión planteada por Bernardo O'Higgins el año 1820 en Concepción en un encuentro con los logko principales de esos territorios, queda abierto así el inicio de la política de invasión.

Lo débil del Estado chileno en sus primeras décadas hace casi imposible que logre su objetivo de anexar el territorio mapuche. El escenario determinaba concentrar esfuerzos en medios y fuerzas en su frontera norte para comenzar los preparativos de una futura guerra contra Perú y Bolivia, razón por la cual en su frontera sur solo se limita a un adelantamientos de fuertes militares, el primer adelantamiento es desde el río Biobío hasta el río Malleko, el segundo desde el río Malleko hasta el río Cautín, una vez conseguidos estos objetivos el escenario es favorable para el Estado de Chile se da a la tareas de definir sus fronteras estatales y comienza sus guerras: primero la Guerra del Pacífico definiendo sus fronteras norte la actual ciudad de Arica y posteriormente la guerra en contra del pueblo mapuche para la anexión del territorio al Estado de Chile "vulgarmente conocida como Pacificación de la Araucanía", la que se desarrolla entre los años 1881 y 1883.

La derrota militar mapuche trajo enormes y desastrosos resultados, que se expresaba en todas y cada unas de sus actividades internas:

1. La anexión del territorio al estado de Chile, aproximadamente 10.000.000 de hectáreas, determinó la pérdida de la independencia, de la soberanía y de la libertad del pueblo mapuche. De ahí hasta el día de hoy hemos sido obligados a vivir, primero en las condiciones de las Reducciones y hoy en las condiciones de las Comunidades.

2. La pérdida del territorio destruyó la base económica ganadera del pueblo mapuche y como resultado de esto comienza a desaparecer vertiginosamente la moneda plata, elemento fundamental para la construcción de las joyas mapuche. El comercio ganadero desaparece y por lo tanto la economía mapuche se readecua a las condiciones de las reducciones, transformando su economía ganadera en una economía agraria de subsistencia familiar que se mantiene hasta el día de hoy de forma predominante. Esta nueva situación es sin dudas la causa fundamental del empobrecimiento mapuche.

3. Las nuevas condiciones impuesta por el Estado de Chile en el contexto de las Reducciones, destruyó también las estructuras sociales de la sociedad mapuche, los antiguos niveles sociales de los lofche, rewe y ayjarewe, fueron literalmente comprimidos o diseminados, en la gran mayoría de los casos suplantados, reubicados territorialmente alejados de sus orígenes, de sus pertenencias sociales y espirituales. 


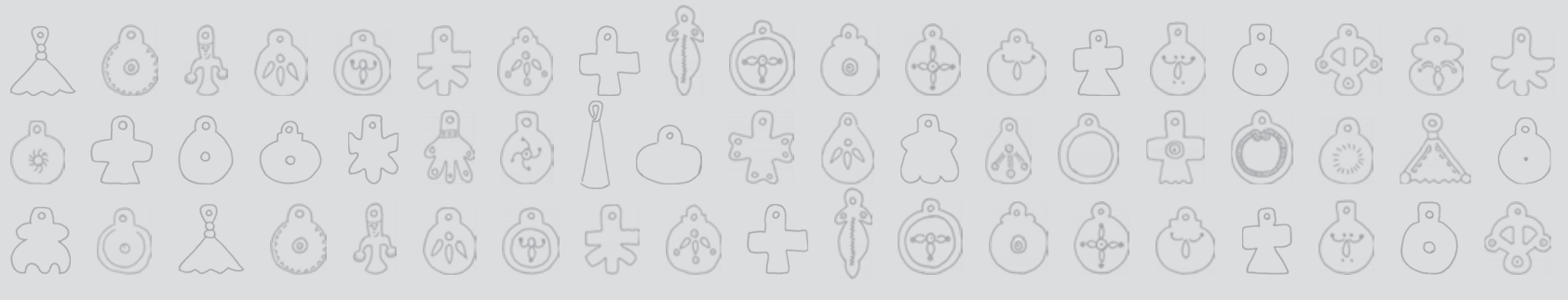

Vale decir que todas las actividades de salud mapuche, educación, lenguaje, religiosidad, comienza a ser desplazado paulatina o violentamente hacia los cánones que impone la sociedad chilena a través de distintas fórmulas y herramientas.

Esta nueva situación trae como resultado que se rompan todas las estructuras sociales en cuanto a roles y funciones de cada uno de los miembros de la sociedad mapuche, los resultados de la misma afectan a la construcción de su platería, ya que el tuwün y el küpalme de las personas y familias determinan las formas y graficaciones de las joyas.

4. Al destruirse las bases económicas y sociales, casi de forma natural se destruyen las bases políticas ya que estas no tienen elementos concretos en las cuales se sustenten. Los logko pierden sus antiguos roles y funciones, ya no se realizan los grandes acuerdos políticos en los xawün, no deciden el precio de los productos, no son los interlocutores con el Estado de Chile, son obligados a asumir tareas de representación con las nuevas autoridades chilenas en el contexto de los pueblos y ciudades que se van construyendo. Vale decir que todo lo relacionado con la salud y medicina mapuche, la educación, el lenguaje entre los más importantes comienza a desaparecer.

Las tareas principales de las estructuras sociales y políticas de esos tiempos (logko, wewpife, gehpiñ, machi, gijatufe, werken, übmeh entre otros) es de readecuarlas a las condiciones de las reducciones, del nuevo escenario de subordinación al Estado de Chile, a sus contacto y relaciones con los colonos que ocuparon los antiguos territorios mapuche y el interés de estos de seguir usurpando las pocas tierras mapuche que van quedando.

El empobrecimiento del pueblo mapuche determina que rápidamente se vaya extinguiendo la demostración de opulencia económica que los logko hacían gala al enjaezar a sus cabalgaduras y al uso personal de prendas de plata.

Los Estados de Chile y Argentina en la segunda cincuentenas del siglo 19, dejan dividido al pueblo mapuche en dos partes hasta el día de hoy. Al vivir en el contexto y bajo la subordinación de ambos Estados, se termina bruscamente el intercambio económico comercial entre puwelche y guluche que era una de las bases del desarrollo de la platería mapuche. En ese nuevo escenario se terminan las alianzas comerciales y militares sobre la bases de los matrimonios, podemos por tanto definir dos grandes momentos de la platería mapuche:

a. $\quad$ El de esplendor en el contexto de la soberanía, independencia y libertad sobre la base de la comercialización del ganado.

b. La decadencia en el contexto de vivir subordinado a dos estados sobre la base del empobrecimiento.

Por lo tanto, al analizar la platería mapuche debemos tomar en cuenta estos dos momentos, uno antes y otro después del año 1883. 


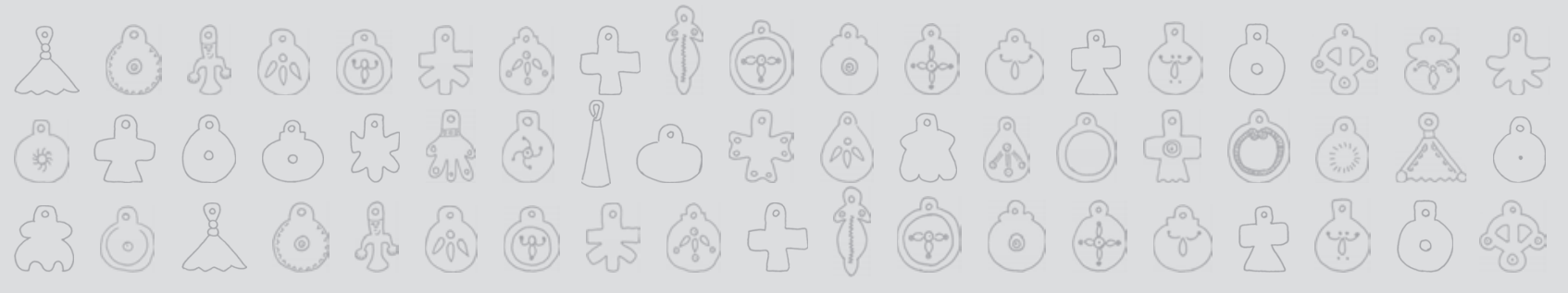

\section{ALGUNAS CONCLUSIONES PRELIMINARES}

1. La Platería Mapuche tiene sus primeras bases en el conocimiento adquirido de la obtención de oro en el trabajo en diversos lavaderos de la zona central con las invasiones Incaicas y la imposición de su doctrina de las tributaciones, podemos decir por tanto que su dirección de avance es de norte a sur de nuestro territorio.

2. El conocimiento de la metalurgia es adquirido durante la invasión española a nuestro territorio cuando estos imponen su doctrina esclavista, primeramente a los pirkumche en la zona central actual, a través del trabajo esclavo en los lavaderos de oro y posteriormente cuando se adentra a nuestro territorio y descubren oro en los ríos Kilakoya, Rere, y Weken en la actual región del Biobío. La esclavización de los jóvenes mapuche es el detonante del desarrollo de la guerra en contra del español invasor de ahí las grandes sublevaciones, levantamientos y la aparición de muchos héroes como Lefxaru y Kajfülikan. Este escenario nos permite conocer el oro, las cadenas de hierro, las picotas, las palas, los chuzos y otros elementos.

Otro aspecto poco conocido o muy poco mencionado es el trabajo agrario-esclavo que los españoles denominaron, "las encomiendas", que no era otra cosa que la repartición de grandes extensiones de terreno que eran entregadas a los oficiales españoles primeramente con los lofche que estuvieran en ellas para el trabajo esclavo-agrario, a través de este conocimos el arado, la echona, los martillos, los alicates, las guadañas, los machetes, etc. Por otro lado, se cumplían funciones como ayudantes o aprendices en las herrerías para la construcción de herraduras, herramientas de distinto tipo, construcción de ejes de carretas, fabricación de barriles y toneles, esto sin lugar a dudas aumenta considerablemente el conocimiento de la metalurgia en la sociedad mapuche.

3. Las distintas etapas de la guerra en contra del invasor español también fueron determinantes para el conocimiento de los metales, son muchos los utensilios, herramientas y otros elementos de guerra que comienzan a ser utilizados en la sociedad mapuche.

4. Sin lugar a dudas fue el desarrollo de la economía ganadera y la comercialización de ganado primero con los españoles, segundo el trasiego económico comercial entre Guluche y Puwelche, tercero la comercialización de ganado con los chilenos, lo que permite crear las bases necesarias para la aparición de la Platería Mapuche y el medio la aparición de la moneda plata.

5. La implementación de la economía ganadera dentro de la sociedad mapuche y el control del poder interno va definiendo en el transcurso de los años la estratificación de de la sociedad mapuche, por lo tanto los roles y funciones en lo social y en lo político deben ser expresados en la construcción de las joyas, las que deben ser únicas.

6. Creadas todas las condiciones materiales, aparece el rüxafe para dar vida a la Platería Mapuche, él será el que condense todo el conocimiento que por siglos acumuló el pueblo mapuche. 


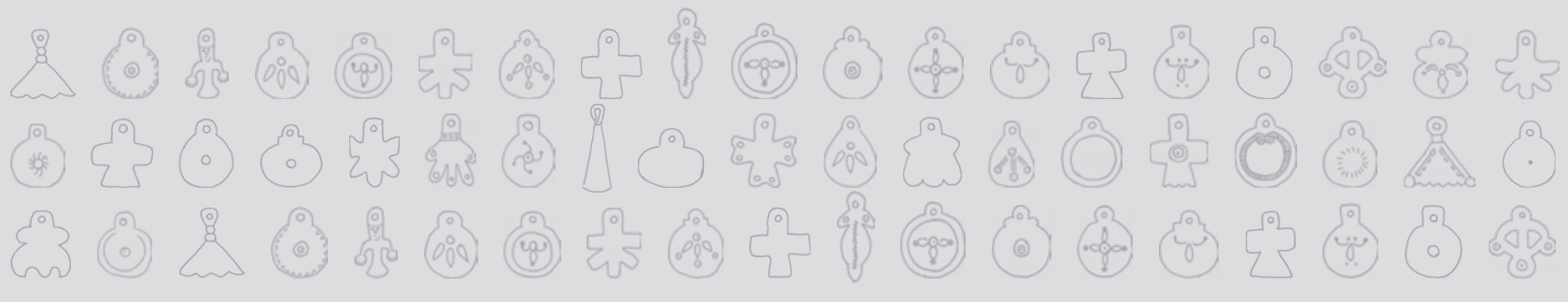

En sus creaciones toma en cuenta las distintas definiciones filosófico-espirituales, considera a la mujer en cuanto a su ubicación en los distintos niveles de estratificación social y en función de su rol en este se le construye sus joyas. Las expresiones y funciones políticas que son propias de los logko son consideradas primero en la construcción del enjaezado de sus caballos y posteriormente en el logko mismo.

7. La Platería Mapuche logra desarrollarse en el territorio del Gulu Mapu en su fortalecimiento trasciende la cordillera, se confunde y amplia en el Puwel Mapu sobre la base de la comercialización de diferentes productos y ganado.

8. La Platería Mapuche se expresa por su uso en la mujer mapuche, luego pasa al caballo y posteriormente se demuestra en el logko y los übmeh como muestra de opulencia económica. 



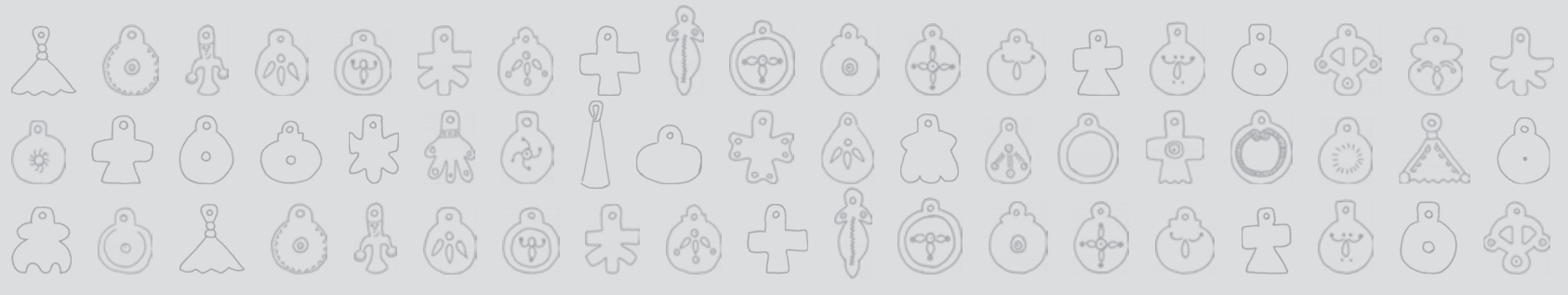

\section{Clasificación de la Platería Mapuche}

La Platería Mapuche es el resultado de las bases filosóficas del pueblo mapuche y de su recreación en el contexto social y político. Considera la espiritualidad del che. Así como la reciprocidad, complemento y el equilibrio entre la mujer mapuche, la luna (küyeh) y el lieg. Toma en cuenta el entorno en la cual se construyen las joyas es decir en el Füta El Mapu y dentro de este: el tuwün, el küpalme, los diversos geh y todos los demás elementos de la naturaleza con los cuales se cohabitan en estos espacios.

Desde la visión mapuche la clasificación de la Platería Mapuche considera una gran cantidad de aspectos que la visión wingka no toma en cuenta, con respecto a esto el peñi Domingo Colicoi (2011) nos presenta la siguiente reflexión:

"En la construcción de joyas el sueño de las personas tiene un peso fundamental, ya que hay una vinculación entre los newenes y los che a través de la espiritualidad, además con los otros elementos de la naturaleza y sus dueños. Los mapuches vemos la platería no tan solo como joyas, sino como una fuerza espiritual un ejemplo en la medicina es el zatun. En algunos gijatunes los (as) machis piden que los logkolleven sus caballos con platería además de las kaskawillas, esto determina que existe un vínculo de todos los elementos a través del lieg (plata), antiguamente algunos logko adosaban a su makuñ (manta) algunas joyas dentro de ella los jifjif (semiesferas).

Los rüxafe se van formando a partir de heredar su función, es como la línea de logko o la línea de la machi. La plata en lo personal me da fuerza y me conecta con otros seres espirituales."

La Platería Mapuche es el conjunto total de piezas de plata confeccionadas por los rüxafe mayoritariamente con plata fundida pero que para su armado toma en consideración otros elementos tales como mostacillas de vidrios, huesos horadados, piedras semipreciosas, monedas de plata de distintos años, amarras de hilo, lanas, cueros, correones de cuero, tendones de choique (ñandú) o de kaweju (caballo), dedales europeos de metal cobre, bronce o plata. Su ubicación está determinada en todo el antiguo territorio mapuche que toma hoy los Estados de Chile y Argentina. La particularidad de la Platería Mapuche está dada por su ubicación territorial dentro del Mapuche Mapu.

A continuación una clasificación de las joyas mapuche considerando las más representativas. 


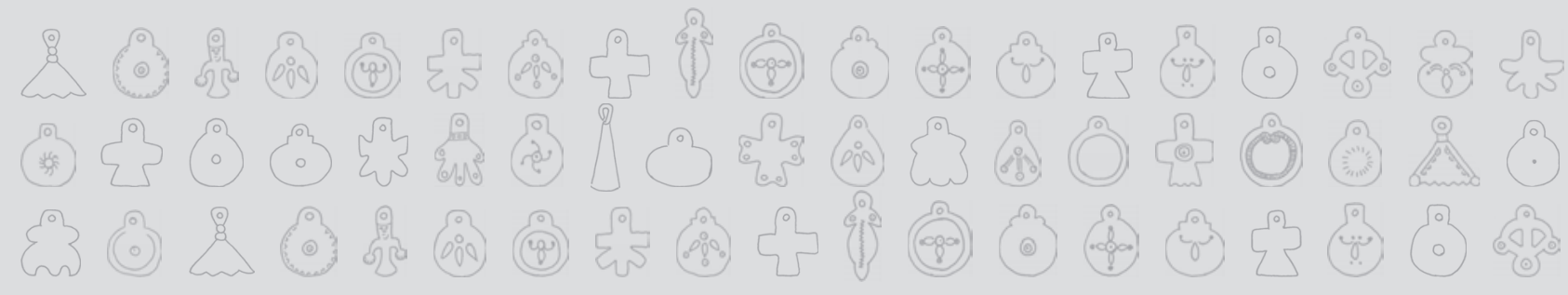

\section{Joyas con bases \\ filosóficas-espirituales \\ Joyas que tienen como base la ubicación social dentro o fuera de los lofche}

Keltatuwe, xarilogko,

süküj, kübkay, punson,

tupu.
Chaway, xariküwü, xarihamuh, rüxil, keltachapewe.

\section{Joyas que tienen como base la dimensión sociopolítica de la sociedad mapuche}

Chumpiru (sombrero) con tachones de plata, xariwtuwe (cinturones) con tachones de plata, rebenques, cuchillos con empuñaduras y fundas de plata, yüwüb küwü (anillos), sipuela (espuelas), pilun chaway (aros de oreja), yu chaway (nariceras), matetuwe (mates), bombillas, iwe (escudillas), entre otros.

Las joyas fabricadas para la dimensión sociopolítica mapuche están confeccionadas a base de la estratificación de los logko y los ülmeh (lofche, rewe y ayjarewe), los que primeramente se expresan en el enjaezamiento de sus caballo y posteriormente en su propio embellecimiento

Al analizar la Platería Mapuche desde el punto de vista de su ubicación territorial (Waj Mapu) estas se dividen en: joyas puwelches y joyas guluches.

Si analizamos las joyas en el contexto del territorio Guluche, estas se dividen en: joyas bafkehche, wenteche, naüqche, wijiche y pewenche. 


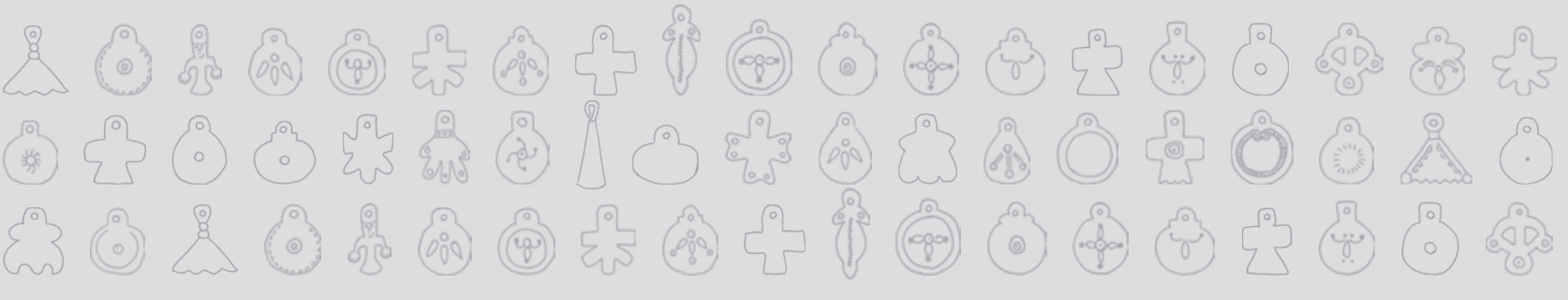

\section{Situación de la Platería Mapuche subordinada al Estado de Chile}

Una vez que el Estado chileno da término a su política de "pacificación", al mismo tiempo comienza la etapa más crítica del pueblo mapuche en donde el empobrecimiento se apodera de casi totalidad de los lofche de lo que hoy es la VIII, IX, y X Región y en la que por supuesto hay un cambio radical en la Platería Mapuche, su construcción se detiene violentamente y lo mismo en el uso de las joyas, todo esto se da dentro de grandes transformaciones dentro del antiguo territorio que pertenecía a los mapuche.

El control social, económico, político y militar de todo el territorio mapuche por parte del ejército chileno determina cambios en ese escenario: aparecen pueblos y ciudades, se construyen caminos que los unan y que tengan comunicación con el centro del país, llega el telégrafo, los puentes, el ferrocarril, se dislocan unidades militares, llega el sistema médico y la medicina occidental, llegan las escuelas y el aprendizaje del castellano es obligatorio, llegan los partidos políticos, llegan diversas iglesias, llega la radio y los periódicos, por nombrar algunos.

Y por supuesto llega el comercio y los comerciantes a los cuales estábamos obligados a vender nuestros productos agrícolas y ganaderos a precios miserables. Cabe hacer notar el impacto negativo que se tuvo para el pueblo mapuche el vivir como en una isla dentro de un océano de colonos chilenos y extranjeros que poseídos de una ambición desmedida, los que como único norte tenía la de esquilmar y robar a las familias mapuche en el contexto de las reducciones, particularmente pintoresco a los ojos de hoy fueron las corridas de cercos en la cual se emplearon los más variados e ingeniosas artimañas.

Otro elemento particularmente interesante de analizar es la militarización del territorio que va al sur del río Biobío, en donde cada ciudad importante tiene ubicado un regimiento, tales son los casos de Angol, Lautaro, Victoria, Curacautín, Temuco, Traiguén, Valdivia. Cuestión que se mantiene hasta el día de hoy (2011) en donde después de más de 135 años de dominación chilena se mantienen zonas militarizadas para el resguardo de los intereses de las grandes empresas forestales y otras inversiones corporativas de nivel más personal de las familias pertenecientes a la oligarquía dominante.

Este escenario que comienza a partir del 1 de enero de 1883 va determinando en el transcurso del tiempo variados fenómenos que tienen que ver con la Platería Mapuche y su deterioro hasta la primera década del siglo XXI, entre los más importantes los siguientes:

1. El empobrecimiento inmediato después de la "Pacificación", tuvo como consecuencia la venta de muchas joyas mapuche que fueron a parar a manos de comerciantes, coleccionistas o a las casas de empeño.

2. La desaparición de la moneda circulante-plata fue otro factor determinante en la no construcción de joyas mapuches y por ende el desperfilamiento del rol y función de los rüxafe dentro de las estructuras 


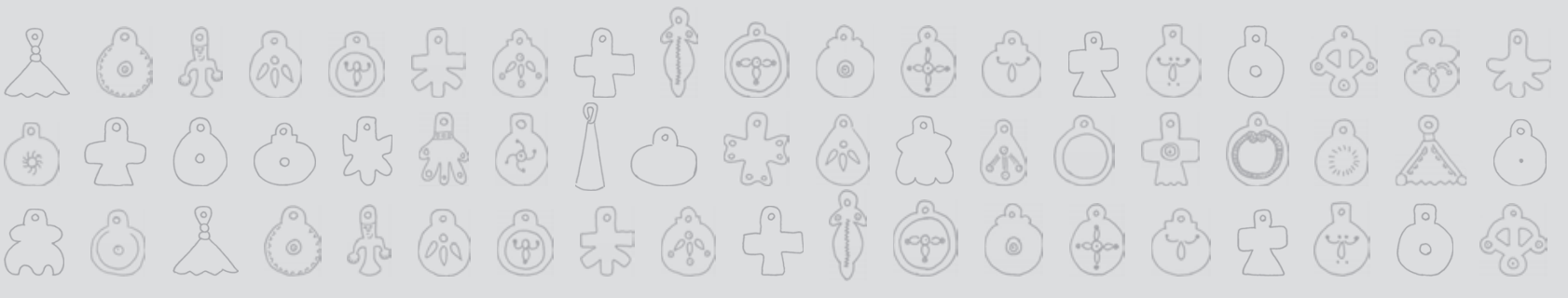

económico-sociales mapuche en las condiciones de las reducciones, la actividad de los rüxafe casi desaparece durante el siglo XX.

3. Producto de la gran represión ejercida a los diferentes lofche, muchas familias entierran sus joyas para que no les sean arrebatadas por el ejército chileno o los saqueadores, las joyas eran guardadas en vasijas de gredas o en ollas de fierro en los mawizantu (montañas), muchos al intentar volver a buscarlos nunca dieron con el lugar, ya que habían crecido las hierbas, los arboles y todo se había transformado.

4. Muchas familias mapuche guardan en su recuerdo el saqueo mediante la profanación de tumbas en los cementerios mapuche, en busca de la platería por parte de los wezake wigka (wigkas malos), quienes les quitaban los ajuares de adornos de los cadáveres.

5. La influencia de las iglesias cristianas tiene mucho que ver con el deterioro filosófico, espiritual y religioso que fundamentan la construcción de las joyas, en algunos casos negando el conocimiento y sabiduría mapuche y en otros tergiversando o tratando de homologar conceptos con el cristianismo en una suerte de sincretismo. Esto es sin ningún lugar a dudas lo más grave que pudo sucederle a la Platería Mapuche ya que destruye las bases mismas de su construcción, afortunadamente se ha logrado salvar y rescatar la mayoría de los elementos fundamentales para su manufactura.

6. La llegada del ferrocarril a estos territorios permitió que algunos chilenos, viendo un buen negocio en la joyas mapuche, construyeron algunas piezas en las maestranzas de los terminales de trenes, mediante la técnica del fundido, utilizando escoria metálica y aumentando cuantitativamente el número de joyas, las que posteriormente eran vendidas o cambiadas por diferentes productos a los mapuches a través de los comerciantes.

7. La pérdida o disminución de la práctica cultural del uso de joyas por parte de la mujer mapuche se va dando también por un proceso de transculturización, en la mayoría de los casos a través de la educación, salud, religiosidad occidental, migración a las grandes ciudades de cantidades importantes de jóvenes mapuches que fueron asumiendo la cultura occidental como la principal y que fue de influencia para las reducciones en cuanto a la cultura.

8. Las universidades, museos y estudiosos no indígena han tenido mucho que ver con el deterioro en cuanto al conocimiento de la Platería Mapuche. El carácter monopólico del conocimiento que las universidades tienen, hacen que sus investigaciones las realicen sobre bases equivocadas en cuanto al conocimiento mapuche, por esta razón sus análisis y conclusiones sean equivocadas, mal interpretadas o maliciosamente tergiversadas, esto sin lugar a dudas a llevado a la Platería Mapuche a un deterioro desde el punto de vista de las bases que fundamentan su aparición, ejemplo de esto es la miniaturización de las joyas mapuche la que cambia radicalmente el uso y función de las piezas.

9. Una de las actividades más importantes para la preservación y proyección de la platería mapuche es el trabajo de investigación y de estudio, ya que esto nos permitirá primeramente rescatar las bases del conocimiento filosófico mapuche que está expresado en la construcción de joyas y por otro lado el estudio de las corrientes, de las modas y del diseño nos permitirá mirar prospectivamente la platería mapuche para finales del siglo XXI. 


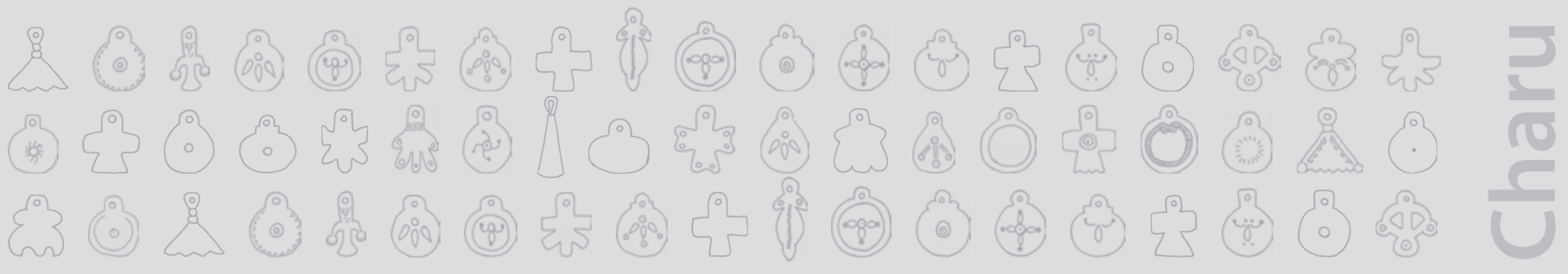

\section{Situación actual de la Platería Mapuche}

En los últimos 50 años, nuestro pueblo mapuche, dentro del contexto de Chile y del mundo ha vivido un proceso de cambios del cual no nos podemos abstraer, más aún si queremos analizar el desarrollo y futuro de la platería. En todo este tiempo ha habido cambios políticos, sociales, económicos, culturales y tecnológicos, que tienen que ver de alguna manera con la platería.

Al inicio de la segunda década del siglo XXI, el pueblo mapuche tiene una dislocación geográfica y familiar muy diferente al siglo XIX. Por el proceso de migración casi el 58\% se encuentra en las ciudades y mayoritariamente en Santiago. También, el rol y función de la mujer mapuche al interior de la familia ha tenido profundos cambios y más aún la mujer mapuche que vive en las ciudades, paulatinamente ha ido ubicándose dentro de las estructuras sociales, políticas y económicas de la sociedad chilena, desafortunadamente en los estratos más bajos en la mayoría de los casos. Todos estos fenómenos traen consigo cambios en el uso y función de la Platería Mapuche que estamos obligados a considerar. No obstante esto siempre habrá un denominador común en sus construcción, en su uso y este es su identidad.

Con respecto a estas reflexiones la lamgen (hermana) Juana Paillalef Carinao, quien es Directora del Museo Mapuche de Cañete, nos comenta:

"El ser mapuche urbana es mi realidad, no es algo que haya buscado, es lo que me ha tocado vivir. La platería para mi es un símbolo, es lo que me fortalece, me identifica en cuanto a mi tuwün, me sube la autoestima, da un sentido de pertenencia a mi vida.

Cuando uso mi platería me conecto con mi pasado familiar y realmente lo disfruto, esto me permite proyectar mi identidad y mi cultura hacia el futuro ayudando a criar a mi nieta Llagka Kura. Tengo confianza en las generaciones nuevas, ya que la cultura es dinámica, se adapta, se modifica, se recrea y por supuesto se proyecta. Esto es lo que creo que va a suceder con nuestra platería".

Todo esto nos obliga a redefinir los diversos mercados a los cuales puede llegar la platería mapuche, el primero y principal son las joyas que se construyen para la mujer mapuche de las comunidades y de las ciudades que entran en función con la norma.

Por otro lado, el vivir en el contexto de la sociedad chilena y en un mundo globalizado nos obliga a considerar dos factores, el primero es que las joyas de la Platería Mapuche se deben construir también para la mujer en general. Segundo, debemos considerar las corrientes y modas en el mundo de las joyas a la hora de construir joyas mapuches. 


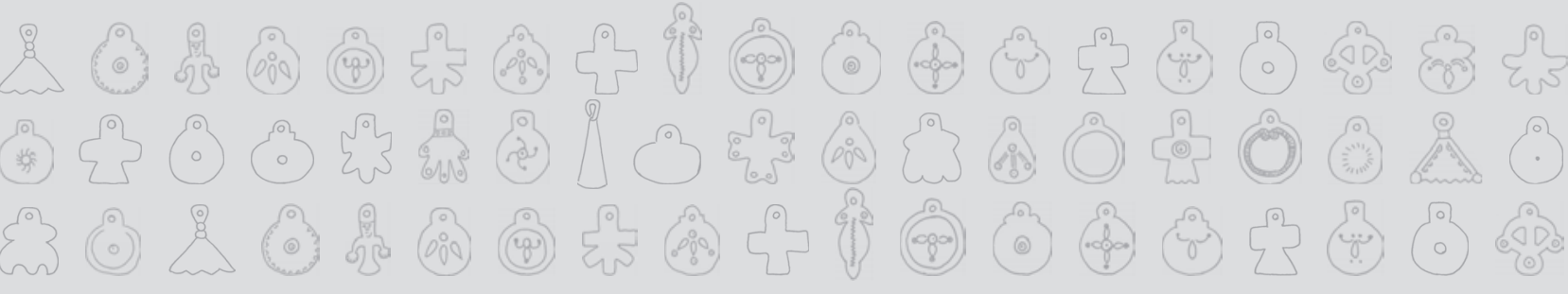

Esto nos enfrenta a grandes desafíos:

1. Utilización de nuevas tecnologías en el proceso de construcción de joyas: el mundo occidental en general va creando nuevas herramientas y maquinarias como resultado del desarrollo científico tecnológico, que obligatoriamente los rüxafe deberán utilizar dentro de los procesos de construcción de joyas.

Esto traerá como consecuencia algunos fenómenos como masificación de algunas joyas mapuche para un mercado que va mucho más allá de las mujeres y hombres mapuches, obligatoriamente se deberá considerar al mundo occidental en su conjunto (fenómeno de la globalización). Asimismo, la industrialización del proceso productivo en la construcción de joyas. Estos dos fenómenos se están desarrollando con mucha fuerza en el Puwel Mapu (Argentina), en donde la producción de platería, cuero, tela y lanas, están casi industrializadas en manos de empresarios wigkas, quienes hacen uso de nuestra simbología e iconos de formas arbitraria y antojadiza.

2. Utilización de nuevos materiales en el proceso de construcción de joyas: como son el uso de pinturas metálicas, piedras semipreciosas y preciosas, cueros, mostacillas de distintos materiales (vidrio, greda) huesos, maderas (por ejemplo Picoyo). Así como la utilización de nuevos metales y amalgamas, como el aluminio, cobre, níquel, acero quirúrgico, bronce, alpaca, níquel-bromo, por mencionar algunos.

3. Profesionalización de la actividad de los rüxafe: iniciación de actividades, marketing, utilización de páginas web para cursos a distancias y creación de museos cibernéticos entre otros.

Elemento importante es el estudio del diseño para su aplicación en los modelos de joyas mapuche, si nos empeñamos en la creación de nuevas joyas debemos adentrarnos al estudio y a la investigación. No cabe duda que muchos jóvenes mapuche estudiarán en las universidades la carrera de Diseño, Artes y otras. En el transcurso del siglo XXI nuestros rüxafe tendrán una formación muy diferente a los de siglos pasados, sin embargo el peso específico seguirá siendo el mismo, el conocimiento de la filosofía mapuche, de su organización social y política antigua a la hora de diseñar y construir joyas, pero lo más importante estará dado por la práctica social-religioso de los rüxafe en términos personales y colectivos dentro del pueblo mapuche.

4. En la primera década del siglo XXI los rüxafe están conviviendo con el mundo occidental casi de forma permanente. Por otro lado a ocurrido que muchos chilenos y extranjeros decidan trabajar 'recreaciones' con muy poco o nada de conocimiento de la cultura mapuche, esto se ha dado por iniciativas personales de algunos orfebres y también ha habido algunas universidades que han tratado de condensar el conocimiento mapuche de la platería y han formado una cantidad importante de orfebres, pero sin una base identitaria como tampoco filosófica mapuche para la construcción de joyas por lo que han concentrado su interés solo en el conocimiento técnico de su construcción. Esto también es un desafío para nosotros los rüxafe, sería poco inteligente oponerse a esto, por el contrario se debe aunar esfuerzos con estos orfebres y darles el máximo de conocimiento de la cultura y de la identidad mapuche (inducción, capacitación, formación), para que esos trabajos sirvan para fortalecer y perspectivar la Platería Mapuche. 


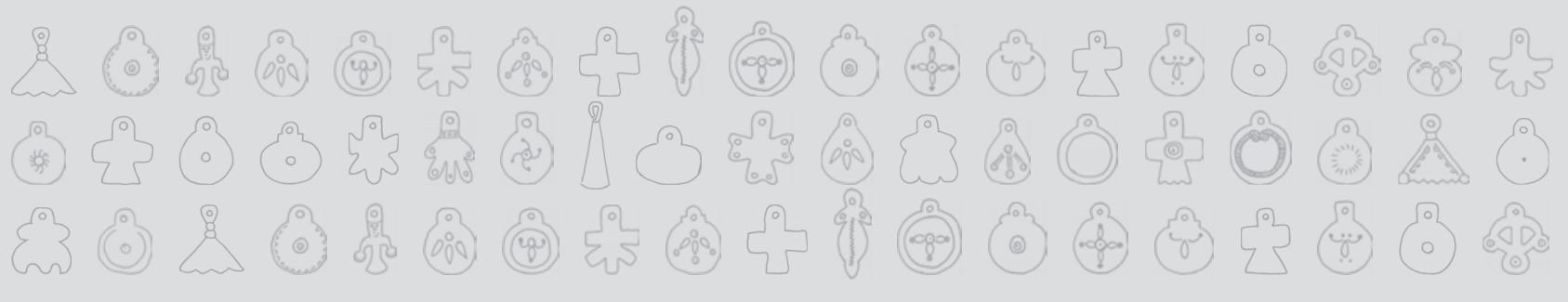

Asimismo, los rüxafe deben y pueden incursionar en las 'recreaciones', ya que es una muy buena manera de rescatar valores culturales y ponerlos a disposición de la mujer en general. Los cambios de todo tipo que han ocurrido en el mundo también los debemos considerar a la hora de analizar el tema de las recreaciones ya que en este sentido no tan solo haremos joyas para la mujer mapuche, sino para la mujer en general. En el mundo actual, las modas, las corrientes, los ensayos, son muy frecuentes y rápidos. Pero además los colores, los materiales, las combinaciones en el uso con diferentes ropas, en diferentes etapas del año, también son de usos muy cortos. Las 'recreaciones' que se hagan, sin duda, serán un aporte concreto a que la Platería Mapuche $y$ a su disfrute en el siglo XXI.

El uso de diversos metales y otros materiales en la construcción de las joyas de acuerdo a las posibilidades económicas es un factor que debemos considerar a la hora de construir joyas, ya que la sociedad occidental y el pueblo mapuche dentro de este, está totalmente estratificado de acuerdo a las capacidades económicas que las distintas familias tengan. Esto obliga a pensar, en cuanto a la construcción de joyas, en las capacidades económicas para comprar joyas, por esta razón el uso de distintos materiales para la construcción de estas es tan diverso, por eso en el mercado actual es tan habitual encontrar joyas en base de la alpaca, cobre, bronce, aluminio, acero quirúrgico, greda, vidrio, acrílico y otros.

El pueblo mapuche actual y sus cultores dentro de ellos los rüxafe que aun existen, deben y tienen la responsabilidad de rescatar, fortalecer, desarrollar y perpectivar la Platería Mapuche en las décadas del siglo XXI y más allá, sobre la base de los cambios que ocurren dentro del Estado de Chile, en el mundo y por supuesto dentro de nuestro pueblo. 



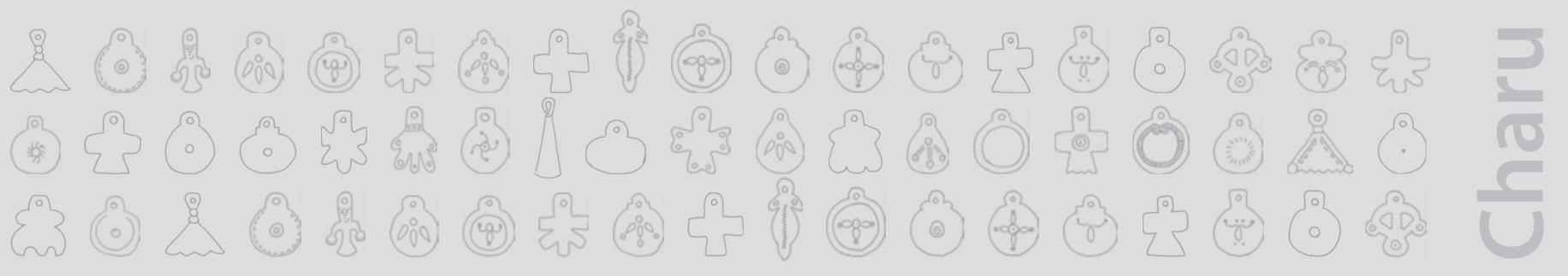

\section{SEGUNDA PARTE}

\section{Bases filosóficas-espirituales}

El pueblo mapuche como cualquier otro, desde tiempos inmemoriales trató de entender de dónde venía la vida, cómo se generaba, quién posibilitaba la vida aquí en el Wajontu mapu, quién generó la vida humana mapuche, cómo es la relación del ser mapuche y los otros elementos de la naturaleza, cuál era la relación entre la vida y la muerte, quién administra y controla la naturaleza, quién administra y controla el género humano en todos sus movimientos espirituales, etc.

Lo mismo ocurre con las formas espaciales del Wajmapu y la distribución espacial espiritual del en ella, como son los movimientos de los distintos elementos que conforman el universo.

Todos estos elementos y muchos más, hay que conocerlos, dominarlos, ubicándose en el pensamiento mapuche para poder entender las bases filosóficas que sirven a los rüxafe bajo la dirección de los logko para la construcción de joyas en la Platería Mapuche. Es absolutamente necesario decir que en esto "no sirven las interpretaciones" de ningún tipo, las personas mapuche y no mapuche deben ubicarse desde la lógica mapuche y tomar en consideración todas sus normas, definiciones que rigen nuestro comportamiento.

Nuestro pueblo después de miles de años logró sintetizar un cuerpo de ideas filosóficas que dan respuestas a todas estas interrogantes antes mencionadas, determinando una serie de conceptos filosóficos con contenidos muy específicos que nos indica cómo se fue generando la vida en general. Este conocimiento se fue transmitiendo de generación en generación a través de la oralidad en la cual juegan un papel importantísimo: logko, gehpiñ, wewpife, machi, gijatufe, bawehgelu, entre otros. Para enseñar a los niños y jóvenes mapuches estos conocimientos se utilizó mecanismo del epew (narración, historia), nuestro pueblo tenía definido un sistema de educación que iba de 4 en 4 años y en transcurso de este iba entregando estos conocimientos (de acuerdo a roles y funciones que los jóvenes iban a asumir en su adultez) los que se reforzaban con la práctica familiar en las diversas actividades espirituales religiosos que se desarrollaban.

\section{PRIMERA IDEA: CÓMO SE GENERÓ LA VIDA}

Dicen los antiguos que hubo un momento en el tiempo en que el universo estaba en completo desorden y caos. Se sucedían grandes explosiones, chocaban las estrellas, hasta que aparece un gran newen (fuerza espiritual), se impone a otros newenes en el cosmos y lo ordena, teniendo como resultado también la generación de la vida en el Wajontu mapu (Globo Terráqueo).

Este gran newen que puede generar vida posee una doble dualidad: tiene las dos energías, la positiva y la negativa, estas no son contrapuestas, sino por el contrario son complementarias, están en reciprocidad y en equilibrio. También posee los dos sexos, el masculino y el femenino que es la única manera de generar vida, 


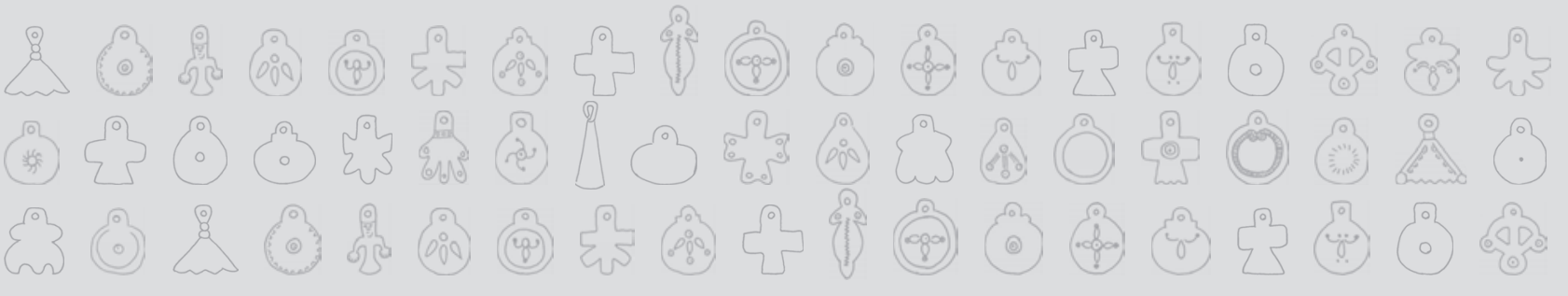

este aspecto es de real importancia ya que de este se sustenta la estructura religiosa mapuche en cuanto a sus autoridades.

Este gran newen tiene por nombre El Mapun y es una gran energía cósmica. La generación de vida en el Wajmapu la lleva a cabo considerando tres elementos: las energías del cosmos en particular la del ahtü (sol), las energías de ko (las aguas mares, lagos y ríos) y las energías de la planicie de la tierra o Naüq Mapu. También estas tres energías deben estar en equilibrio, complemento y reciprocidad, para que esta condiciones se mantengan en el tiempo es fundamental el desarrollo de actividades espirituales religiosas que el ser humano mapuche lleve a cabo a partir de las rogativas y de los agradecimientos.

Así aparece la vida de la naturaleza en el Wajontu mapu: aparece el tiempo y los años, el día y la noche, la luna, los truenos, los relámpagos, los ríos, los lagos, las montañas, las nieves, el viento, las lluvias, el calor. También aparecen árboles, plantas, animales, peces, insectos, pájaros. Todos y cada unos de ellos con energías y sexos para su multiplicación, todos distribuidos en la planicie del Wajontu mapu con espacios definidos y con dueños, los geh.

\section{En el keltatuwe es donde se condensa la filosofía y la espiritualidad mapuche}

Al ver las distintas joyas de la Platería Mapuche, debemos detenernos a analizar el keltatuwe (prendedor), ya que en su placa superior están expresados los contenido de la idea de cómo aparece la vida en general en la naturaleza.

Nuestras autoridades mapuche: Fücha Chaw, Kushe Nuke. Mür (paridad), xürgen (simetría), son principios de la vida, no solo opuestos o complementarios, intrínsecamente necesarios y origen en sí. Meli Newen, Weche, Üjcha expresan la experiencia, sabiduría, juventud, fuerza, vigor, creación engendradora y fecunda, todos ellos nos entregan las bases religiosas mapuche para la construcción futuras de las joyas. Los rüxafe lograron definir un diseño que considerara estos elementos como es la dualidad y determinaron que fuera un cuerpo de pájaro con dos cabezas, que a veces están enfrentadas y otras veces están mirando en direcciones opuestas. Él porque es un pájaro otras veces es la graficación al parecer de una gran mosca, está determinado a que son los únicos que pueden volar tan alto hacia el cosmos y que pueden desaparecer de nuestras vistas tratando de demostrar el infinito del universo.

Nuestros antepasados crearon este diseño de la placa superior del keltatuwe, basándose en la armonía, en el equilibrio (es una pieza simétrica), a veces en ella está la figura de un rostro con formas humanas, que según sea representa a Elmapun (a veces tiene grandes orejas). 

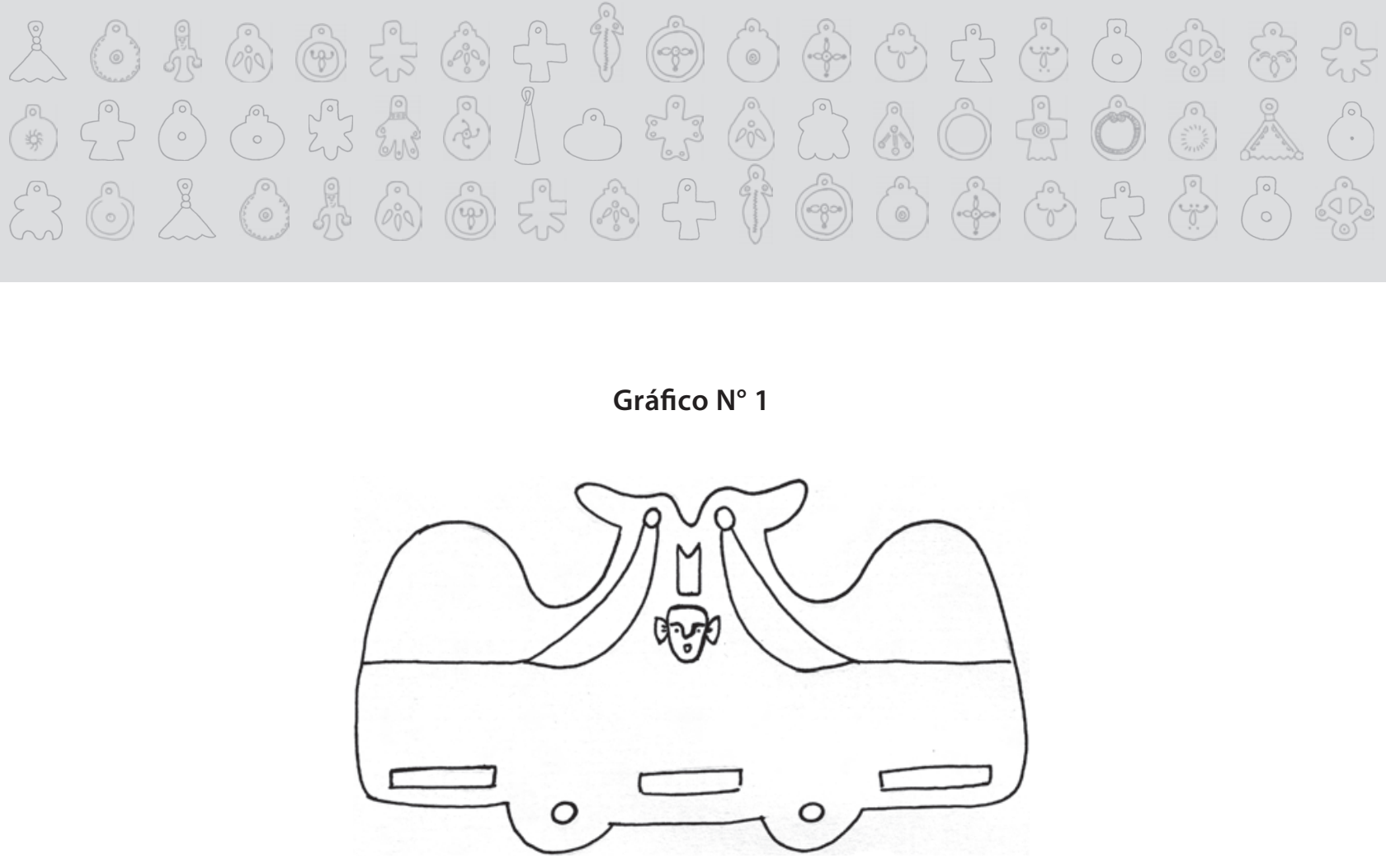

\section{SEGUNDA IDEA: CÓMO SE GENERA LA VIDA HUMANA MAPUCHE}

Los antiguos decían que pasado mucho tiempo, hubo otro gran desorden en el universo y que también afectó al Wajontu mapu, produjo grandes cambios y aparece un gran newen (fuerza espiritual también cósmica) que ordena a otros newen más pequeños que no obedecían las normas, este gran newen que se llama Elchen toma con su mano a los desobedientes, se los lleva a su boca, los mastica y los escupe hacia el universo, muchas de ellas transformadas en estrellas quedando suspendida en el infinito. Pasado mucho tiempo en el firmamento había una estrella muy triste la que lloraba por no estar acompañada, Elchen la toma en sus manos, la transforma en mujer y la deposita en el naüq (superficie), luego toma otra estrella la transforma en hombre y la coloca junto a la mujer para que lo acompañe, de esta manera Elchen depositó varias parejas en distintos lugares por donde sale el sol, a estos lugares espirituales se les denomina tuwün (el origen), ahí los espíritus se recrean, se reproducen y definen los roles y funciones que cada uno de nosotros, mujeres y hombres que tendremos cuando nacemos en el naüq (Epew de Wagübeh).

El canal de la vida humana viene por la mujer y cuando nacemos todos los mapuche tenemos una dualidad: una parte orgánico-biológica y una parte espiritual, el espíritu en vida se denomina püjü.

En la placa superior del keltatuwe están expresados todos estos contenidos de nuestra filosofía. Las diversas incisiones que tiene así lo demuestra, el canal de la vida en general que tiene diversas formas (ver gráfico $N^{\circ}$ 2). Lo mismo el tuwün, el que se expresa también en una incisión que tiene varias formas (ver gráfico $N^{\circ} 2$ ). 


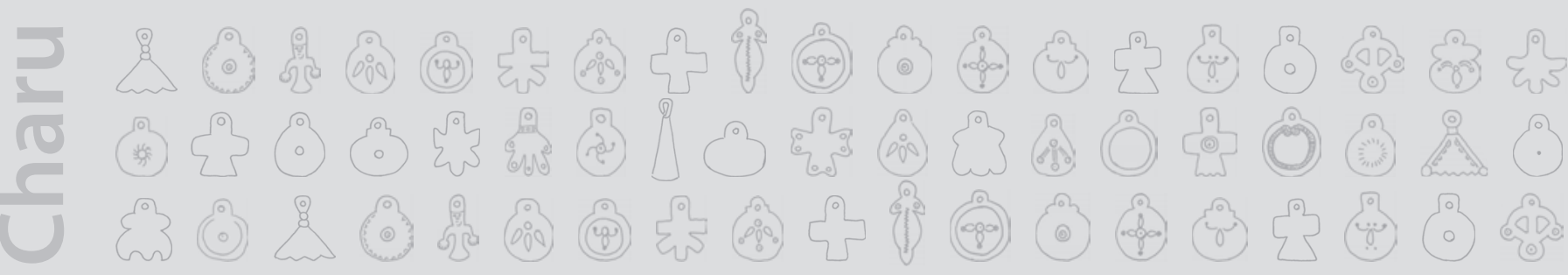

\section{Gráfico № 2}

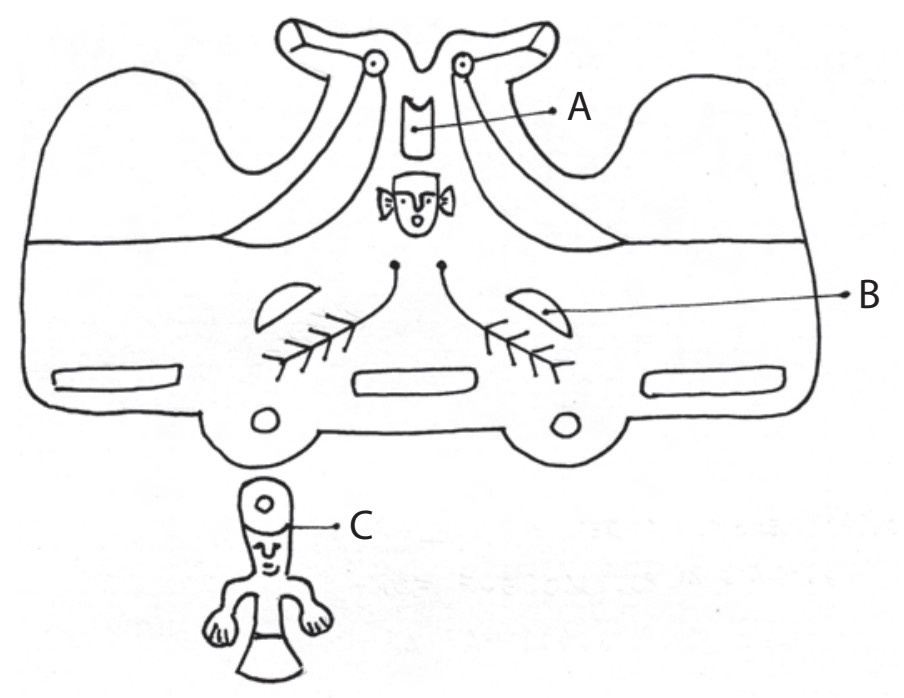

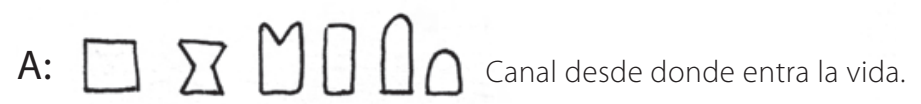

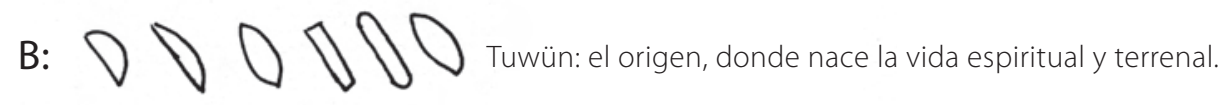

C: Püjü: mujer y hombre mapuche que fueron los iniciadores de la familia.

La incisión que representa al tuwün tiene varias líneas que las unen a otra línea que tiene un comienzo y termina en dos orificios de los cuales penden unas figuras denominadas püjü que representan a los iniciadores o fundadores de las familias en el Naüq Mapu (la planicie del Wajmapu), estos fundadores de las familias quedan en la memoria colectiva y sus espíritus quedan representando dentro de esta placa superior del keltatuwe (ver gráfico $N^{\circ}$ 2). 


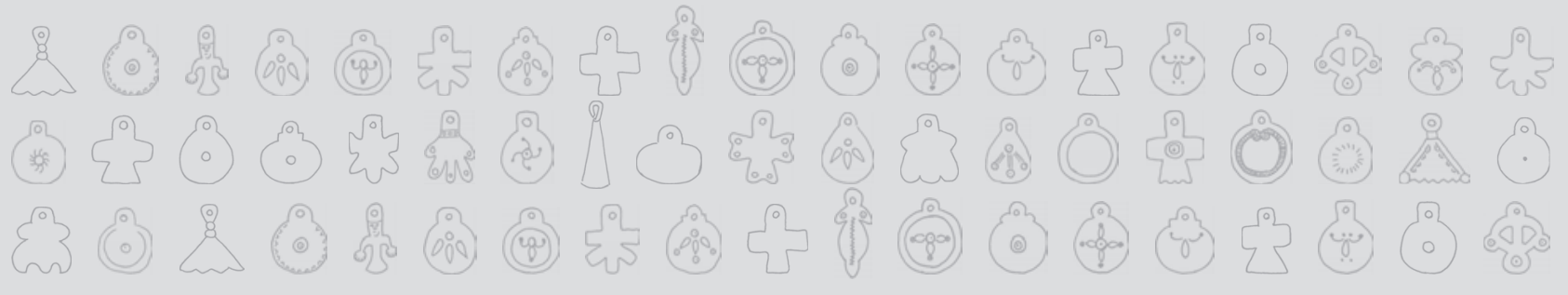

\section{TERCERA IDEA: QUIÉNES CONTROLAN Y ADMINISTRAN EL FUNCIONAMIENTO DE LA VIDA DE LA NATURALEZA EN GENERAL Y DE LA VIDA HUMANA MAPUCHE}

Dentro del contenido de la filosofía mapuche existen un gran newen que denominamos Günemapun, quien administra y regula la vida en la naturaleza en conjunto con los geh los que tienen como tarea fundamental mantener los equilibrios, las reciprocidades y los complementos.

Toda la naturaleza está llena de vida espiritual y existen normas para su funcionamiento que no se pueden trasgredir, los seres humanos mapuche debe cohabitar y coexistir con los demás elementos de la naturaleza en un ambiente de respeto.

También existe un gran newen que denominamos Günechen quien administra y regula la vida humana mapuche en sus diversos movimientos en los diferentes espacios espirituales por el cual transitamos, por lo tanto los mapuches debemos regirnos por normas de comportamiento y de relación para coexistir con los demás elementos de la naturaleza. Son de suma importancia las normas relativas a los roles y funciones que los mapuches tenemos dentro de nuestra sociedad, lo mismo a la relación y subordinación a las grandes fuerzas o Newe que posibilitaron la vida.

En la Platería Mapuche y en particular en el keltatuwe esta atmósfera de espiritualidad se encuentra en forma expresa en las tres cadenillas que unen la placa superior con una placa inferior, en ella se expresa la subordinación que tenemos los mapuches a los newen que generaron la vida.

Nuestras autoridades y los rüxafe lograron definir de forma magistral estos elementos filosóficos en la construcción de las cadenillas que unen ambas placas, pero además desde el punto de vista técnico lograron darle movimiento a la pieza completa, equilibraron la pieza dejando un poco más corto la cadenilla central y obtuvieron también un sonido melodioso (ragaw).

En la gran mayoría de los keltatuwe estas cadenillas son de eslabones, en otras son de placas (con diversos grabados) y las hay también de tubos. Cabe hacer notar que existen algunos keltatuwe de machi que tienen una placa intermedia en que unen las tres cadenillas y que hacen notar su papel de intermediación entre los generadores de la vida y los mapuche en el Naüq Mapu. 


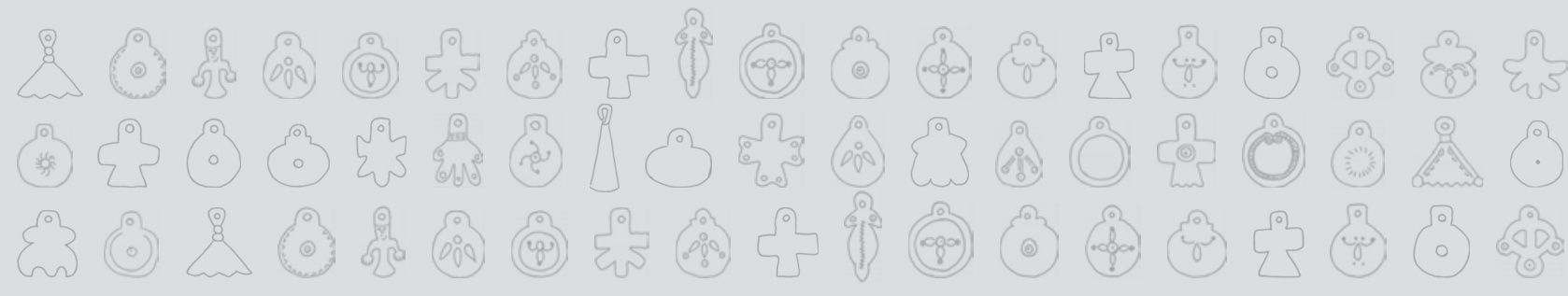

\section{Gráfico $N^{\circ} 3$}

Cadenillas de distinto tipo
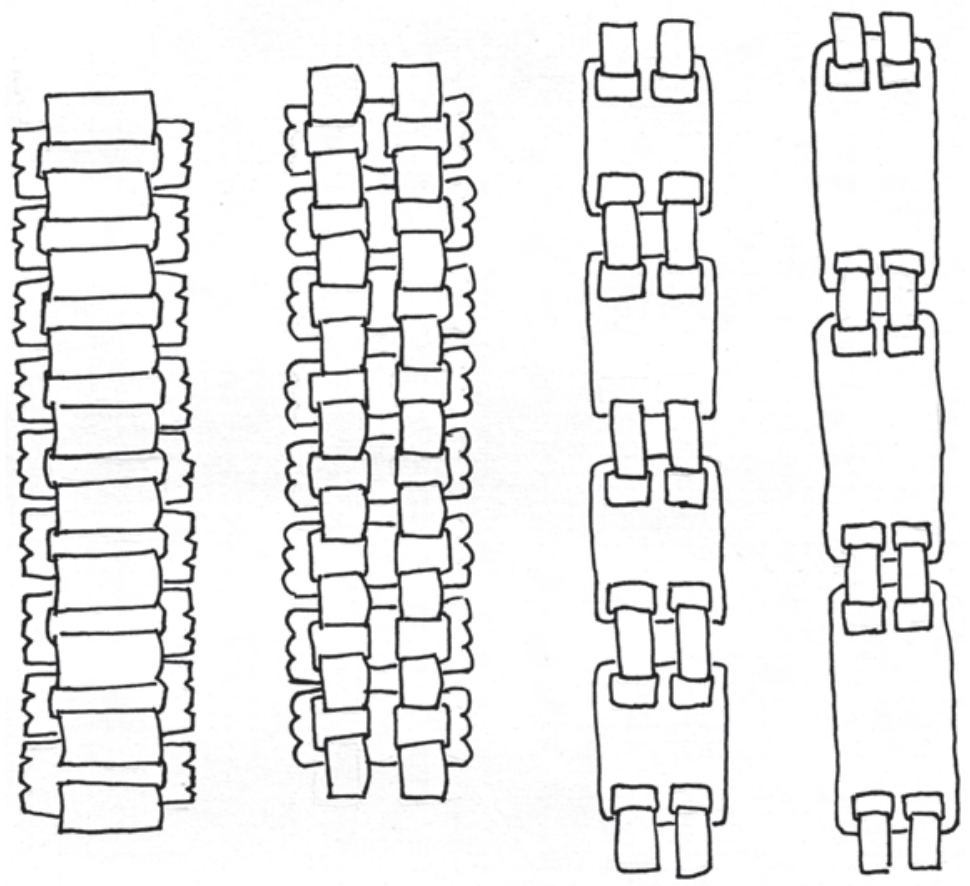

Unidas a estas tres cadenillas se encuentra una placa inferior que representa la vida humana en el Naüq Mapu, esta pieza es proporcionalmente más pequeña que la superior y en ella se quiere graficar la vida humana mapuche normal y espiritual, sus formas obedecen a los criterios de diseños que nuestras autoridades y rüxafe consideraron a la hora de armonizar la pieza en su conjunto.

Günemapun y Günechen están representados en algunos keltatuwe en la placa inferior en su centro con la figura de un rostro humano, pero normalmente, la graficación existente obedece al gijatufe del lof o rewe al cual pertenece la mujer que usa la joya, en sus bordes externos están estampadas dos líneas paralelas y paralelas a esta una corrida de estampados como semicírculos que representan las diferentes familias participantes. 


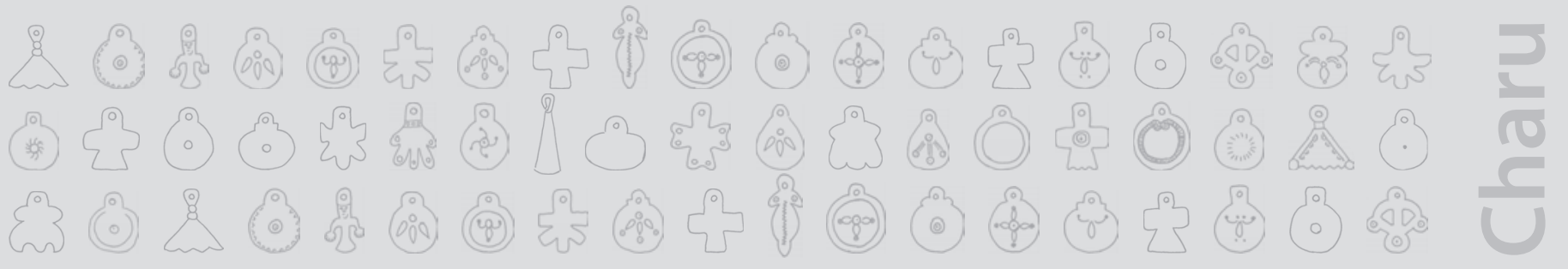

\section{Gráfico $N^{\circ} 4$}

Diversos diseños de la placa inferior, algunos toman en cuenta la representación del gijatuwe y de los newen Günemapun y Günechen
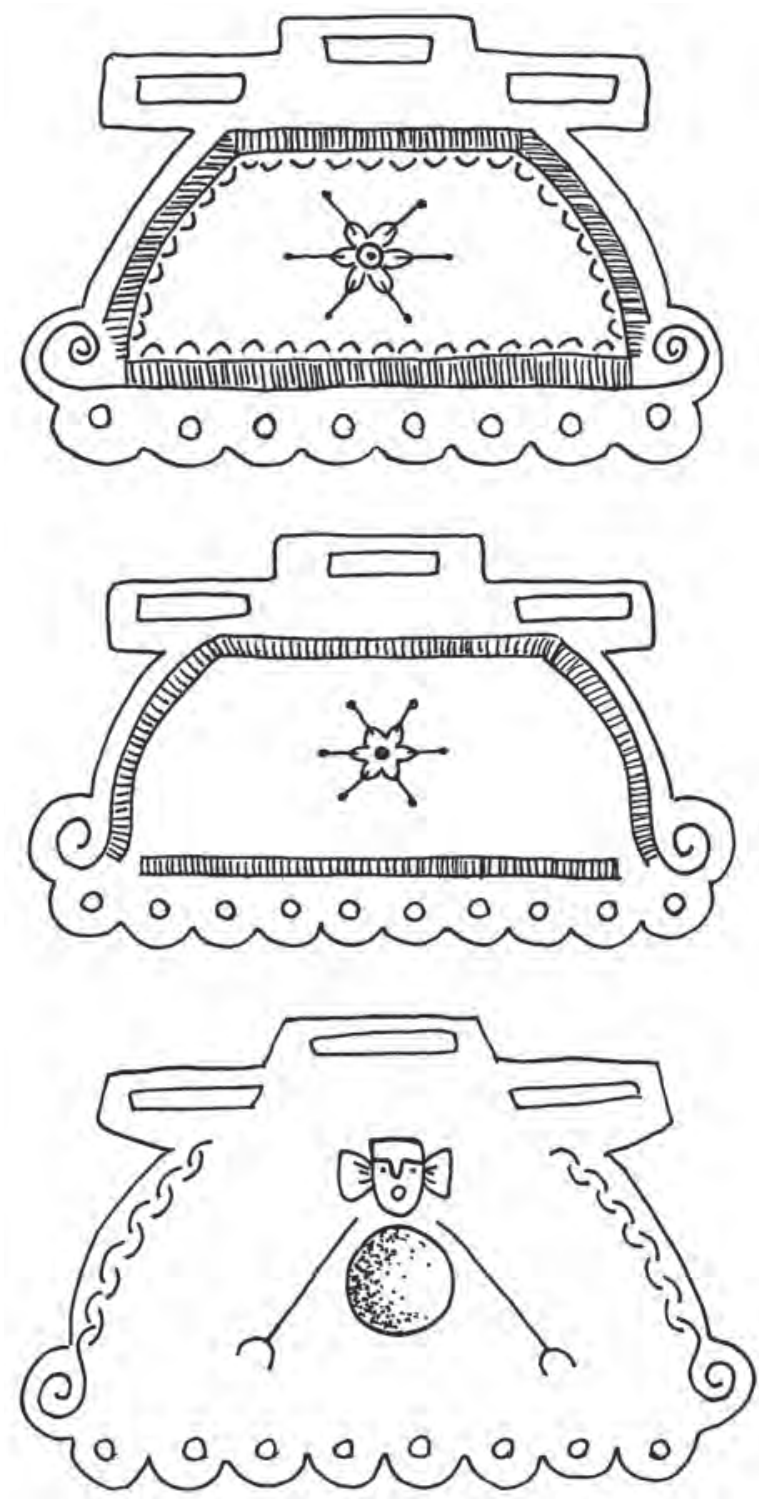
El último elemento del keltatuwe son una series de pines que cuelgan de la placa inferior, su número van de seis a doce pines según sea la composición de lof en cuanto a las familias directas que lo compongan y a la cual pertenezca la mujer mapuche que use la joya.

Sus formas, estampados, globulaciones o incisiones corresponden a la definición que hagan nuestras antiguas autoridades y los rüxafe, las que toman en consideración lo más característico del tuwün de cada familia. Antiguamente cuando una mujer se casaba se iba a vivir a la familia de su esposo y adoptaba su tuwün, el cual se representaba a la hora de distinguir a los pines del keltatuwe.

\section{Gráfico $N^{\circ} 5$}

Diversos pines conocidos en los keltatuwe
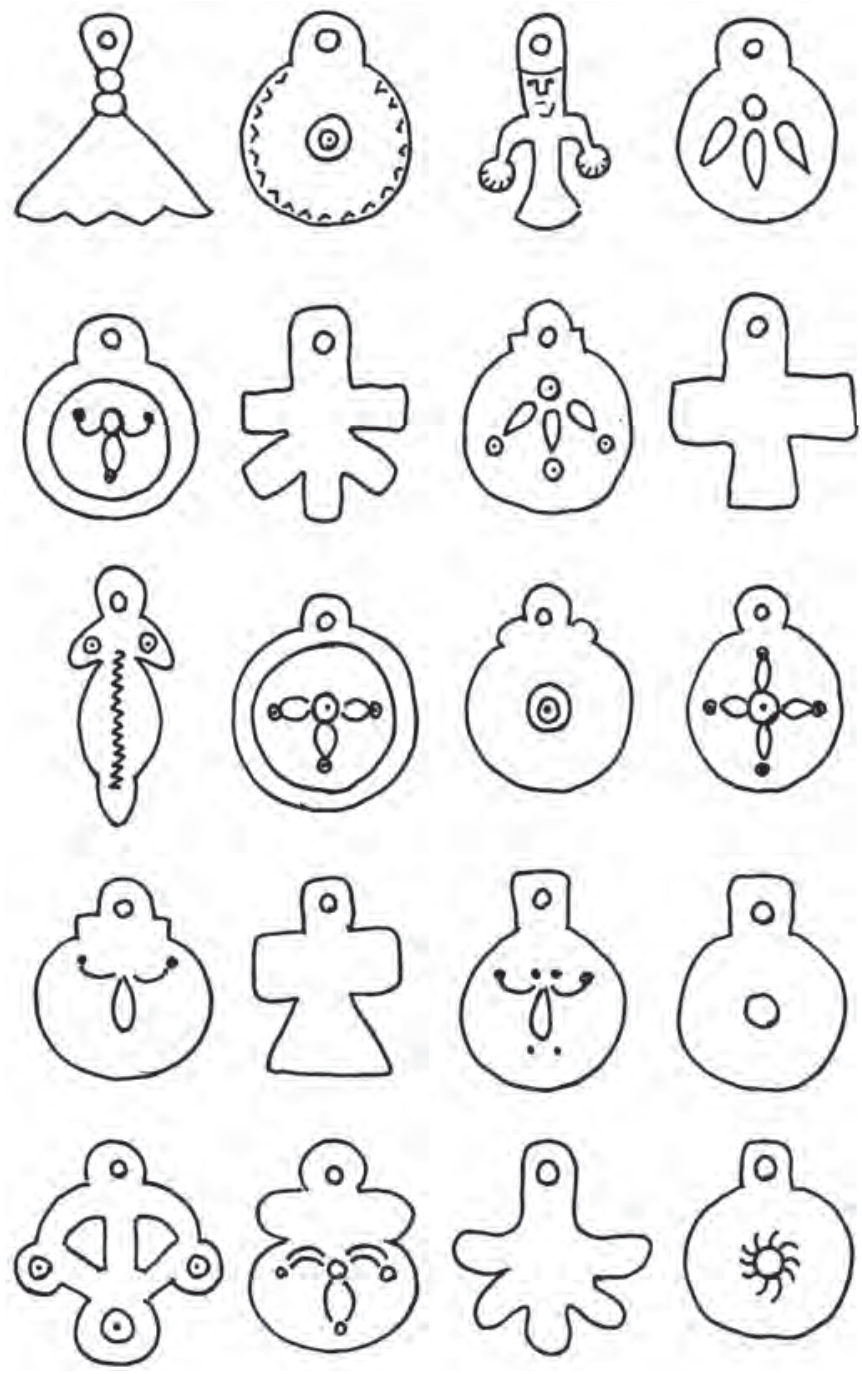


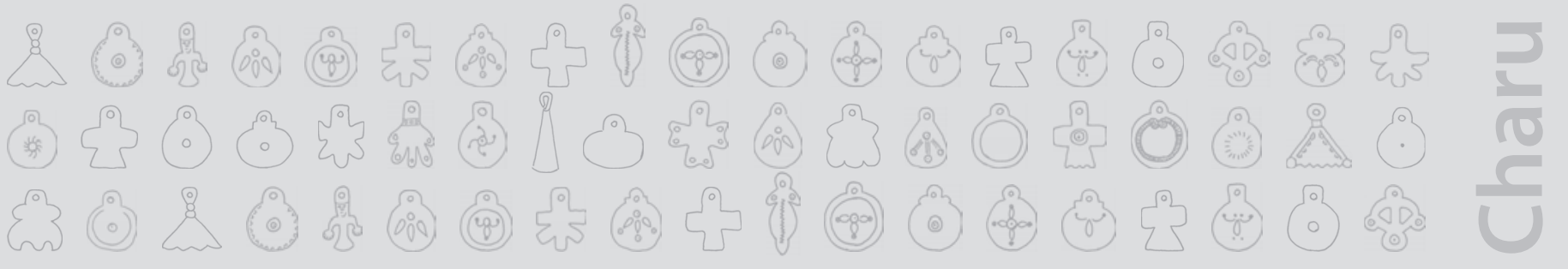

Como podemos ver en el análisis esta joya el keltatuwe es la pieza principal de la Platería Mapuche ya que en ella están la gran mayoría de los conceptos filosóficos que como pueblo nos dimos para entender el mundo en el que nos encontramos y la relación espiritual a través de nuestras rogativas con las energías cósmicas que nos dieron vida.

Desde la visión técnica de la construcción de la pieza se puede ver con meridiana claridad en sus distintos diseños: la armonía, el equilibrio, el movimiento, la sonoridad, la alegría y la unidad de sus partes en un todo único e irrepetible.

\section{Gráfico $N^{\circ} 6$}

Keltatuwe
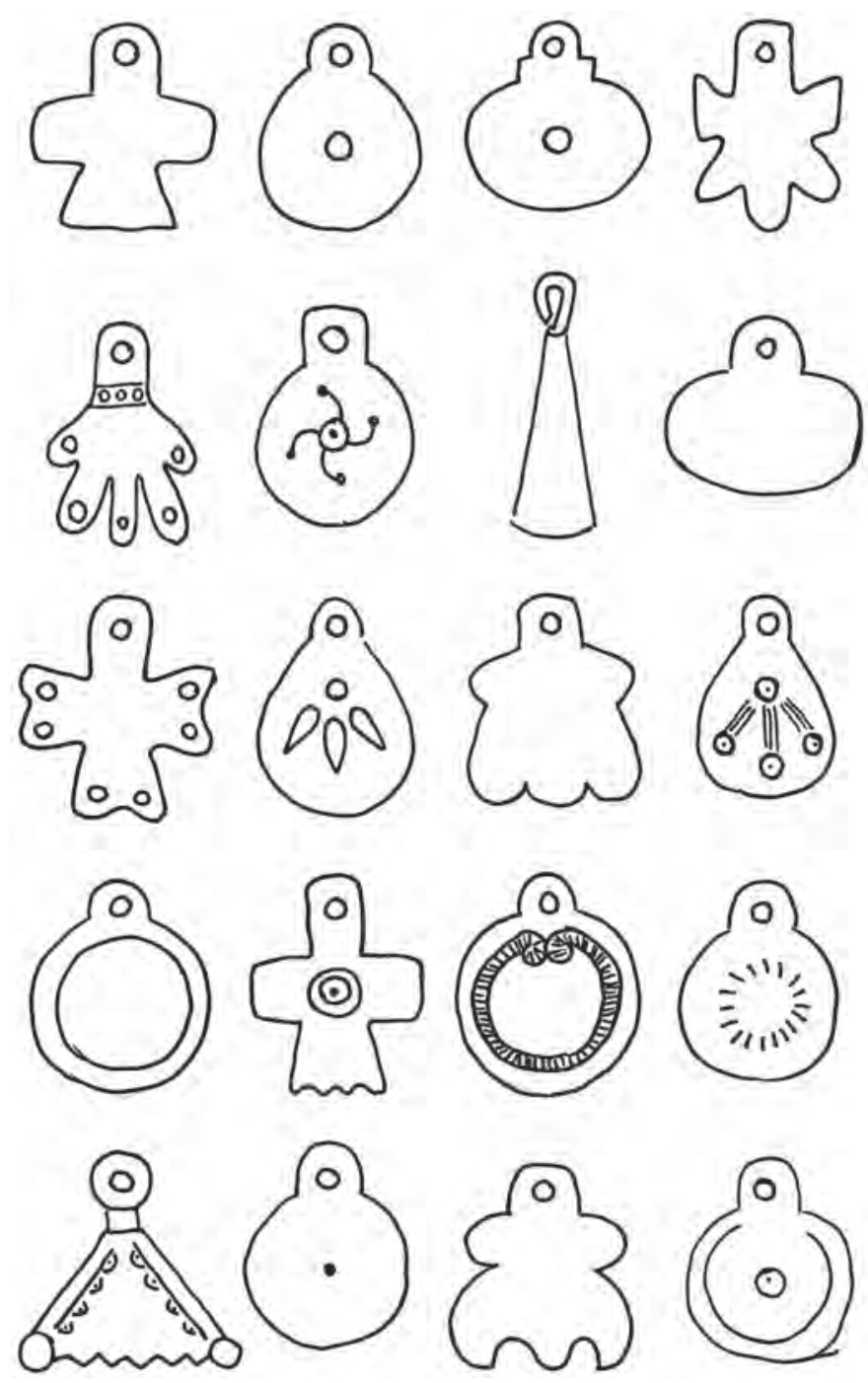


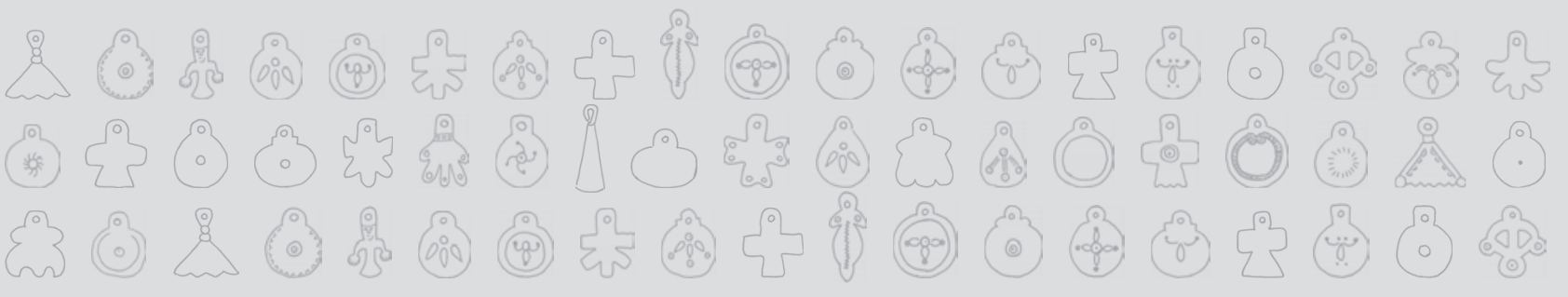

\section{CUARTA IDEA: CÓMO ES LA RELACIÓN ENTRE LA VIDA Y LA MUERTE EN EL MUNDO MAPUCHE}

Este concepto mapuche que dice relación con la vida y la muerte está expresado en la construcción de una joya mapuche que llamamos süküj y que es un pectoral que va a un costado del keltatuwe.

Los antiguos decían que la vida comenzaba y terminaba en el tuwün y que volvía a comenzar y que en este espacio espiritual los espíritus tienen dos cabezas y dos corazones, por lo tanto los mapuches nunca íbamos a desaparecer.

La relación entre la vida y la muerte es un todo único, siempre en constante movimiento y ocupando diferentes espacios espirituales por los cuales a los mapuches nos corresponde transitar, para luego volver en cuarta generación, o sea los mapuche creemos en la reencarnación o en algo semejante.

El primer espacio espiritual es el tuwün, este se encuentra en algún lugar de la planicie del Wenu Mapu y es donde se da el origen de la familia mapuche. En él se recrean los espíritus, se casan, se multiplican, se definen los roles y funciones que tendrán en vida, preparándose para dar inicio a su movimiento espiritual hacia el Naüq Mapu, dejando una cabeza y un corazón en el tuwün.

El segundo espacio espiritual es el Naüq Mapu. Aquí nacemos, crecemos, nos desarrollamos, procreamos y luego morimos. Durante la vida somos duales: una parte nuestra es orgánico-biológico y la otra es espiritual. Nuestro espíritu en vida se llama am y nos acompaña siempre, es parte de nuestra actividad espiritual personal, sociocolectiva, familiar y se une a la espiritualidad de la naturaleza. Cuando nos morimos nuestro am sale del cuerpo, y se transforma en püjü (espíritu en movimiento), este deambula por unos días por donde estuvimos en vida y luego comienza su movimiento a otro espacio espiritual (Püjü Mapu) que también se encuentra en algún lugar de la planicie del Naüq Mapu.

El tercer espacio espiritual es el Püjü Mapu. Este es un espacio espiritual en donde se reúnen generacionalmente los espíritus de los miembros de cada una de las familias que se encuentran en el Naüq Mapu.

Antiguamente (hasta 1883) las familias mapuche estaban compuestas por varias líneas generacionales como por ejemplo, estaba la línea generacional del logko, de los hermanos de él y los primos paternos del mismo, pero podría estar la línea generacional de los hijos del logko y de los sobrinos del mismo, también podían estar la línea generacional de los nietos de logko y de los sobrino-nietos del él. Hacia atrás podía estar la línea generacional del padre del logko y de los tíos paternos del mismo y más atrás podía estar la línea generacional del abuelo del logko y de los tíos abuelos del él, todos con sus respectivas esposas, todas estas líneas generacionales un lofche.

Por esta razón, los miembros de una línea generacional una vez que iban muriendo se iban reuniendo espiritualmente en el Püjü Mapu y cuando completaban la línea comenzaban otro movimiento hacia otro espacio espiritual (ragiltu wenu o anka wenu). 


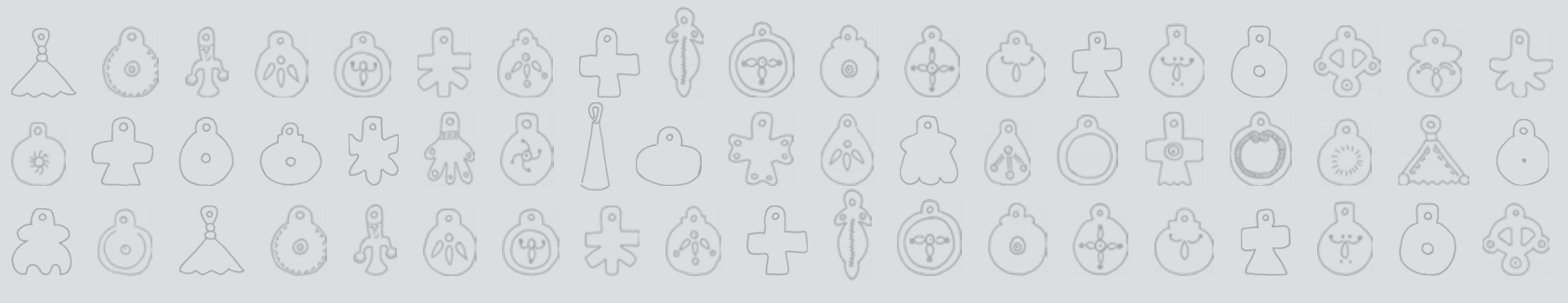

Cuarto espacio espiritual es el Ragiñtu Wenu o Agka Wenu. A este espacio espiritual llegan los espíritus generacionalmente y en él los püjü se purifican, porque según la filosofía mapuche, el che con su püjü en vida tiene actos buenos y actos malos, nadie nace bueno o malo y se mantiene así en vida, por lo tanto según la visión filosófica mapuche lo que corresponde es la purificación y cuando llega la otra línea generacional continua su movimiento hacia otro espacio espiritual (tuwün, el origen) en donde los espíritus nuevamente unen sus dos cabezas y sus dos corazones.

El próximo movimiento espiritual será nuevamente hacia el Naüq Mapu por lo tanto la filosofía mapuche determina el concepto de la reencarnación en cuarta generación. Todos estos movimientos espirituales están definidos por una serie de normas que su incumplimiento generan enfermedades espirituales en todos sus movimientos

De esta manera están establecidos los distintos movimientos espirituales en la relación entre la vida y la muerte según la filosofía mapuche. Nuestros antepasados definían que el movimiento completo necesita aproximadamente entre 80 y 120 años. Otro aspecto relevante es que el movimiento espiritual es circular y que va en sentido de derecha a izquierda.

Si analizamos dentro de la Platería Mapuche al süküj nos daremos cuenta que en él están explicados detalladamente los cuatro movimientos. Esta joya está compuesta por cuatro placas unidas entre sí casi siempre por dos eslabones, cada una de ella tiene grabaciones, incisiones, globulaciones, diferentes estampados, sobre relieves de distintos tipos. Todo esto considerando las particularidades de los movimientos en los cuales está inserta la dueña de la joya. Los diversos diseños construidos son de una estructura bastante grande pero los hay también más pequeños. Los süküj están sujetos al chamal por medio de un punson o de un tupu.

De la última placa penden de cuatro a ocho pines, sus formas y grabaciones corresponden al tuwün de la familia que los mandó a construir. Las formas de las placas casi siempre son rectangulares y la placa inferior tiene una forma de trapecio y es de mayor superficie que las placas superiores. 


\section{Gráfico $N^{\circ} 7$}

Mostraremos las formas del movimiento espiritual mapuche y la reencarnación

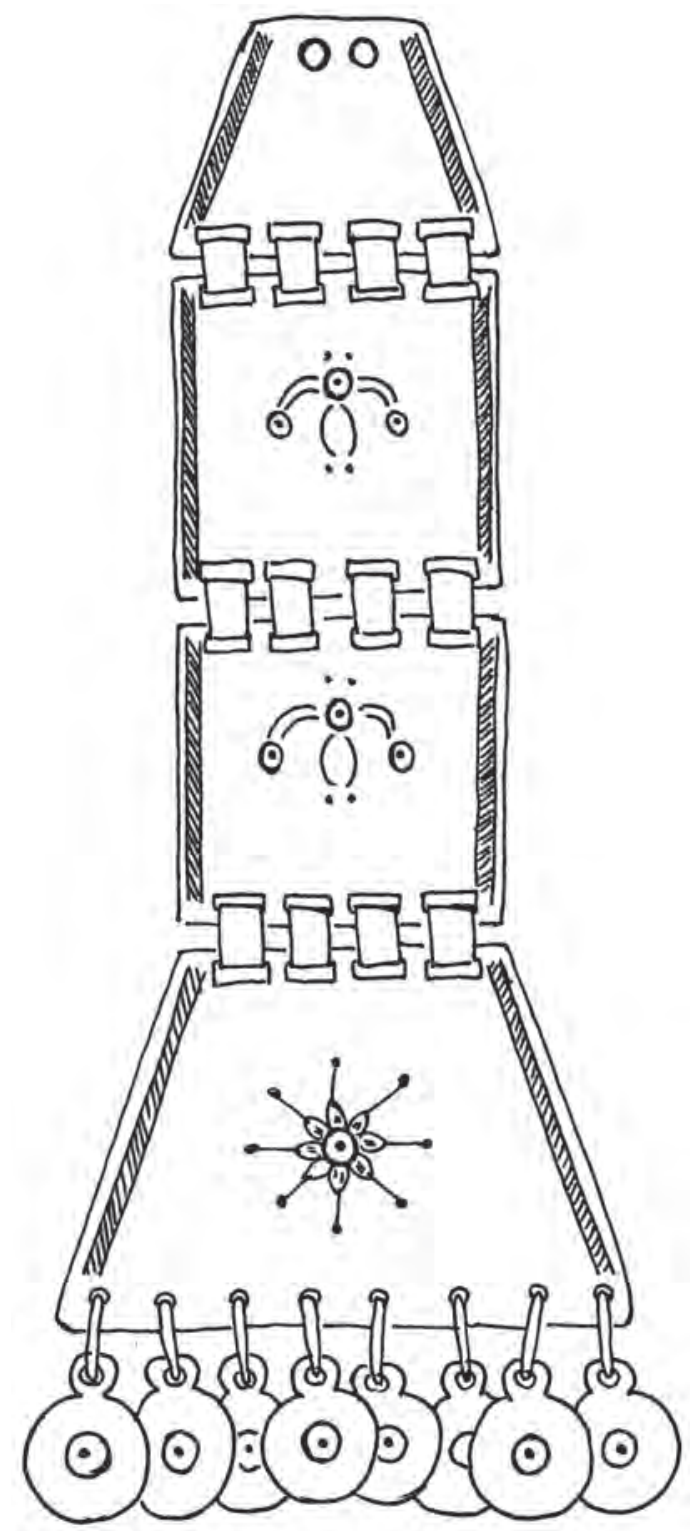




\section{Gráfico $N^{\circ} 8$}

Mostraremos algunos Süküj

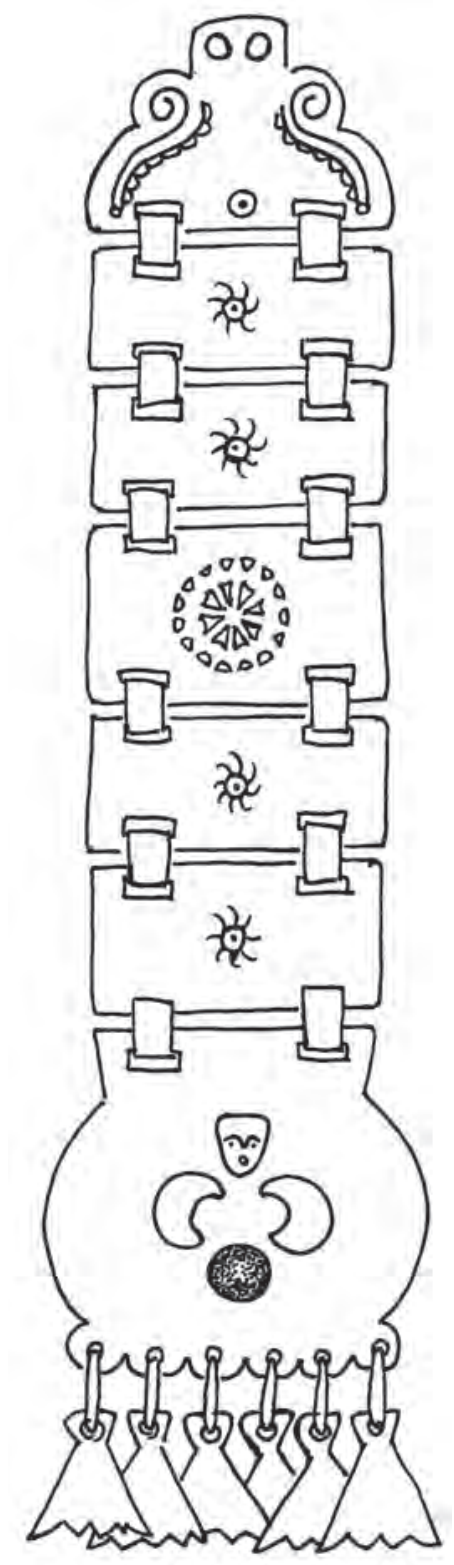




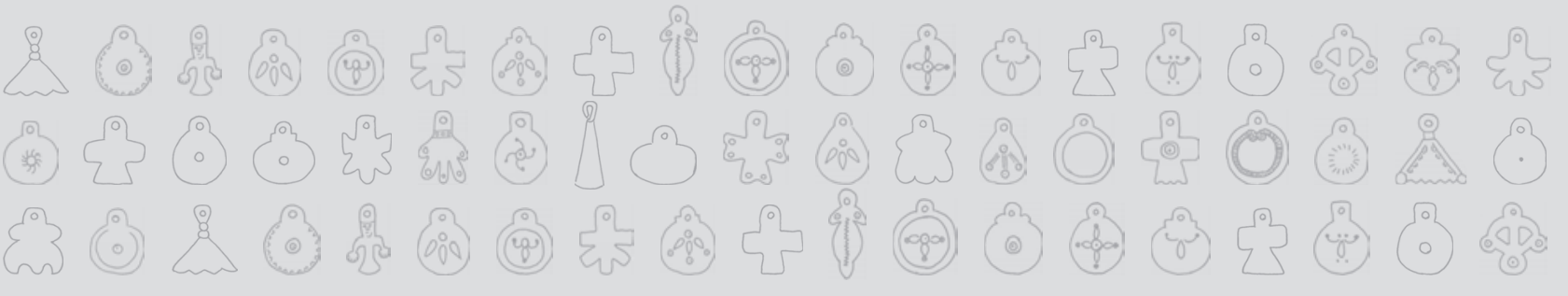

\section{QUINTA IDEA: LAS FORMAS ESPACIALES DEL WAJMAPU}

Otra interrogante que nuestros antepasados trataron de responder en sus análisis filosóficos fue las formas físicas del Wajontu mapu.

El estudio del Cosmos fue una tarea permanente por parte de las autoridades mapuches, se tenía conocimiento de las diferentes constelaciones y se les denominó Wagübeh Bewfü (río de estrellas), sus movimientos y ubicaciones en las diferentes etapas del año mapuche, lo mismo se estudiaron algunas estrellas y astros.

Se estudió detenidamente el movimiento de la luna, su influencia y determinación de una serie de actividades como son el nacimiento de animales, sus castraciones, etapas de siembras y de cosechas, análisis y definición de cambios climatológicos de acuerdo a los cambios de la luna. Lo más importante del estudio de la luna fue la definición del año lunar mapuche que lo componen 13 meses de 28 días y que está en correspondencia con los cambios hormonales de la mujer de ahí la relación inseparable entre la mujer y la luna. Se estudiaron y definieron los diversos momentos de la luna durante la noche.

También se estudió al Sol, su ubicación y sus comportamientos durante las diferentes etapas del año mapuche, se llegó a determinar el comienzo del año lunar mapuche o We Xipantu y sus cuatro momentos más característicos, a partir de su inicio con el Pewü, Pukem, Walüg, Rimügen (desde la visión occidental las cuatros estaciones del año), en base a esto se determinaron los comportamientos del sol respecto al Wajontu mapu. Nuestros antepasados determinaron los comportamientos y los distintos momentos del Sol distribuidos en el día y los comportamientos del che respecto a estos. El ahtü (sol) se define como elemento desde donde viene las energías que dan vida al che, de acuerdo a esto se definen las ubicaciones de muchos elementos como es la ubicación de las entradas a las ruka, la definición de cómo se debe dormir con la cabeza en la dirección por donde sale el sol y así muchas cosas.

Lo más trascendente en la definición de las formas espacial del Wajontu mapu fue que el sol giraba en torno a él, lo mismo el resto de los elementos del universo. Lo que determinaba que el Wajontu mapu estaba estático en el universo y todo giraba en torno a nosotros por lo tanto éramos el centro del universo que veíamos.

Esta aseveración nos permitía mediante la observación repetitiva ubicar la salida del sol casi siempre en un mismo lugar, salvo pequeñas variaciones de acuerdo a las etapas del año. Otro resultado de la observación fue que el sol aparece en el Xipawe Ahtü (oriente) y luego comienza a subir a medida que transcurre el día y parece alcanzar su mayor altura arriba de nuestras cabezas wixan antü, para luego descender hasta desaparecer en el horizonte en la dirección del Kon Ahtü (occidente).

Al otro día da la impresión que vuelve a aparecer en el mismo lugar, esta observación de mucho tiempo y de muchas generaciones permitió al pueblo mapuche definir este primer concepto circular del Wajontu mapu.

Otro elemento que es fundamental para determinar las formas espaciales del Wajontu mapu son los distintos movimientos de los vientos. La observación de nuestros antepasados determinó que los vientos que corren 


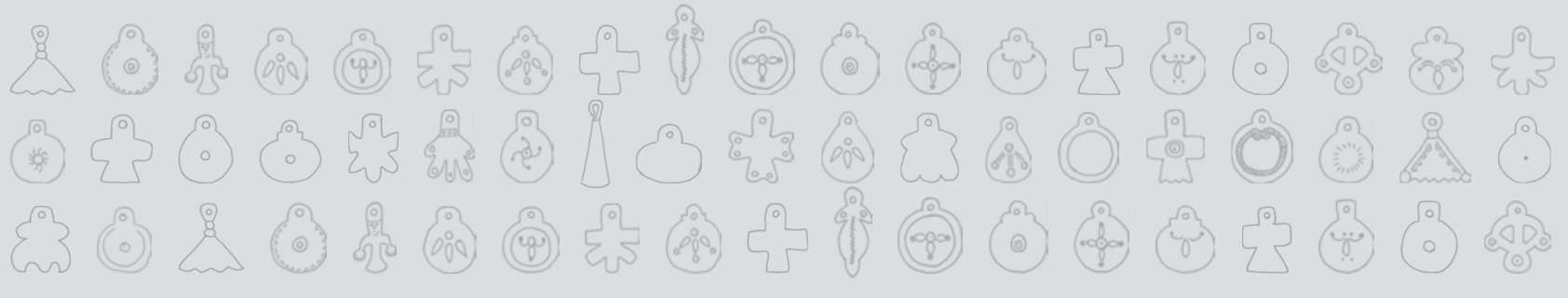

de sur a norte paralelo a la cordillera de los Andes determinan que las particularidades climáticas sean marcadas y características dentro del año o sea tendremos un invierno lluvioso, una primavera con mucha vegetación, un verano caluroso con mucha abundancia en alimentos y un otoño con vientos y lluvias.

Pero si por el contrario los vientos que predominan son de norte a sur paralelo a la costa, estos producirán grandes cambios climatológicos: muchas lluvias e inundaciones, sequías, grandes heladas entre otras. Por estas razones nuestros antepasados creían que los vientos debían tener sus movimientos equilibrados y complementarios para tener un año normal y al seguir imaginariamente los dos movimientos al mismo tiempo, parados en un Xeg Xeg y mirando a la salida del sol, teníamos entonces otro gran círculo en donde el che era el centro, así de esta manera nuestros antepasados definieron este segundo concepto circular.

Nuestros ancestros enseñaban a los niños y a los jóvenes mapuches estos conceptos subiéndose a un Xeg Xeg y en estas elevaciones observaban los movimientos del sol y de los vientos y definían los dos conceptos circulares, siendo el che el centro de ambos y cerrando los ojos se podía imaginar estar en el centro de una gran esfera, este era el mundo mapuche.

De esta manera el Wajontu mapu es una gran esfera que está dividida en cuatro espacios: Wenu Mapu, Ragiñ Wenu Mapu, Naüq Mapu y Miñche Mapu.

Todos estos conceptos espaciales del Wajontu mapu están contenidos en el kulxug, instrumento musical sagrado de los mapuches, el que es utilizado por nuestras y nuestros machis en distintas ceremonias. Esto que parece tan simple, para nosotros los mapuche es más complicado ya que en el kulxug están prácticamente todos los conceptos filosóficos que nuestros antepasados definieron como un gran cuerpo de ideas que norma nuestros comportamientos y nuestra relación con todos los newen.

Tuve la fortuna de conocer a mi abuelita paterna Magdalena Huircapán Pilquil, ella murió a los 108 años de edad en el lof Kuwelche, a quien solicité me enseñara cómo era el Mundo Mapuche y es este su relato el año 1970:

"Mis abuelos y las personas sabias de mi rewe, nos enseñaban muchas cosas buenas para los mapuches, no me recuerdo del tiempo pero yo era muy chica. Nos decían que cuando el Naüq Mapu se movía y las aguas se salían, todos teníamos que subir al Xeg Xeg, todos los mapuche sabían cuál era su Xeg Xeg, el de la familia es ese wigkul (cerro) que está aquí en frente y que se ve todo el río Cholchol.

Algunos Xeg Xeg que tienen tres o cuatro patas y hay que subir por los lomos cuando hay problemas. Los ancianos antes explicaban cómo era el Wajontu mapu, llegaban al Xeg Xeg antes que amaneciera para ver por donde salía el sol y como iba subiendo durante el día, hasta que se perdía por el otro lado y era como un arco, así dicen que era el Wajontu mapu". 


\section{Gráfico $\mathbf{N}^{\circ} \mathbf{9}$}

Forma espacial del Wajontu mapu

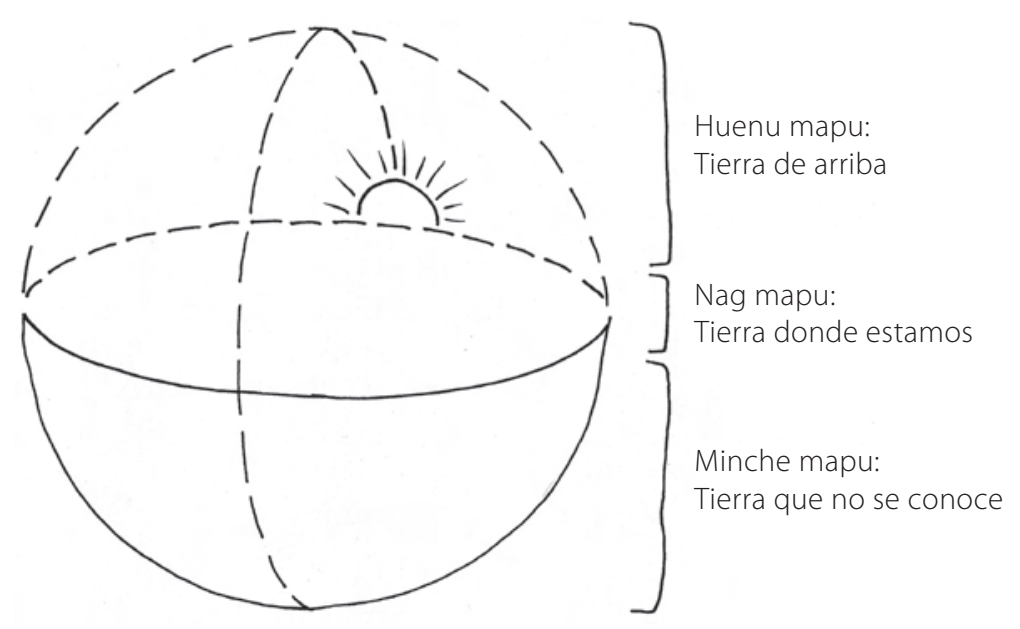

Si analizamos estos conceptos espaciales aplicados a la Platería Mapuche nos daremos cuenta que estos se expresan de manera magistral en el punzón y en el tupu, ambos están construidos bajo esta lógica.

El punzón muestra cómo es el Wajontu mapu en su dimensión espacial, es una gran esfera. En el caso del punzón a la esfera se le adosó una gran aguja que en su parte inmediata tiene un orificio y al otro lado de la esfera tiene como un cabezal de la cual pende un püjü con formas humana pudiendo representar a Elchen o a Günechen, otras veces cuelgan otras formas. El tupu sin lugar a dudas representa la planicie del Naüq Mapu.

El tupu es un gran disco de plata al cual se le adosa una gran aguja que puede estar soldada o remachada al disco. El uso y función de ambas pieza es para fijar otras piezas como son los süküj al chamal o a la üküja. Hay pueblos originarios en el norte como los aimaras y quechuas que usan actualmente y desde tiempos inmemoriales esta pieza llamada tupu y cumple los mismos fines que las nuestras que es el fijar otras piezas a la vestimenta principal.

Desde el punto de vista técnico de la construcción de ambas piezas podemos decir lo siguiente:

1. Para la construcción del punzón se utilizan dos discos de iguales dimensiones, sobre los cuales se aplica la técnica de percusión sobre un dado metálico y se golpea hasta crear dos semiesferas, las que son soldadas con soldaduras de plata para posteriormente adosar una cinta metálica que tiene por objetivo tapar la soldadura anterior. Posteriormente se realizan dos perforaciones tomando en cuenta el centro de la esfera para colocar una aguja grande y que quede por el otro extremo de la aguja un trozo cilíndrico de metal que es esculpido con diversos motivos y al que se le prende un püjü. Los punzones pue- 


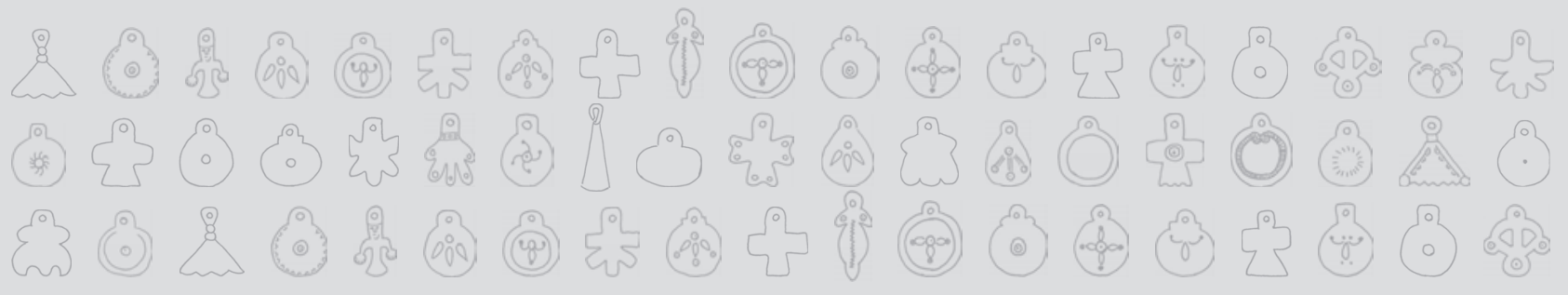

den ser de diversas dimensiones y con graficaciones diferentes de acuerdo a la decisión de la persona que manda a construir la pieza.

2. para la construcción del tupu se utiliza un gran disco de plata sobre el cual se trabaja para dar formas a variadas graficaciones, que representan diversos aspecto de la vida mapuche en el Naüq Mapu o en su defecto graficar conceptos filosóficos como es el Meli Wixan Mapu. En algunos casos para la construcción de los de los tupu se utilizan diversas técnicas como es el repujado, las incisiones, los estampados, los burilados, los sobre relieves, etc. Creando de esta manera una infinidad de modelos manteniendo ese sí el carácter de disco en todos ellos. Es importante decir que a los tupu se le adosa una aguja grande la cual puede ir soldada al disco o en su defecto puede ir remachada.

\section{Gráfico $\mathbf{N}^{\circ} 10$}

Mostraremos dos o tres punzones y dos o tres tupu

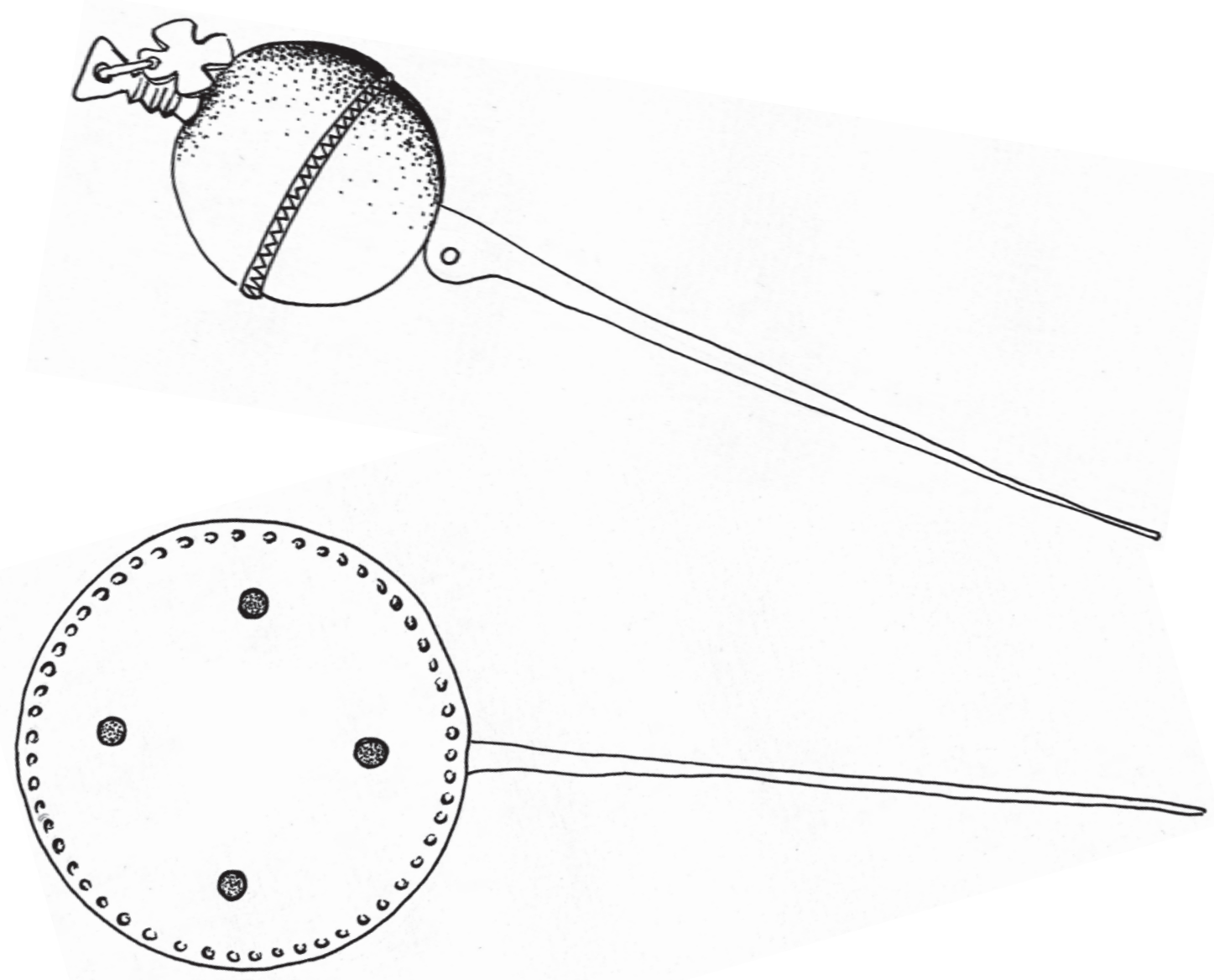




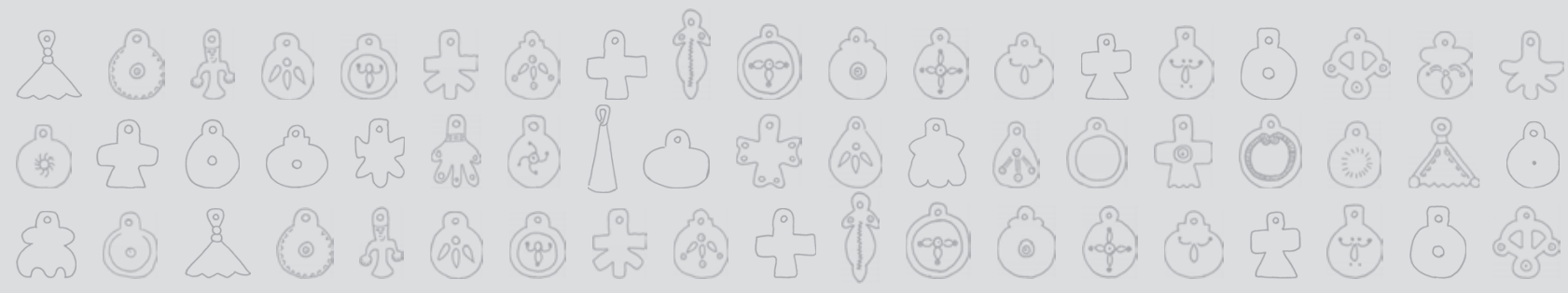

Desconozco, o conozco muy poco acerca de la distribución espiritual dentro del Wajmapu y fuera de este por esta razón no hago referencia a este aspecto.

\section{SEXTA IDEA: CÓMO SE SOSTIENE EL WAJMAPU}

La lógica mapuche logró definir también otro concepto filosófico que dice relación con dar respuesta a la pregunta ¿cómo se sostiene el Wajontu mapu? ¿Qué bases tiene? Nuestros ancestro después de observar y discutir llegaron al contenido del concepto del Meli Wixan Mapu que podría significar las cuatro fuerzas o tensiones que sostienen el Wajontu mapu, se entendía por tanto que estas fuerzas salían fuera del Wajontu mapu hacia el cosmos.

Este concepto arroja tres resultados que es necesario que lo consideremos para la construcción de joyas:

1. El primero dice relación que el Wajontu mapu es el centro del universo y los demás elementos giran en torno a él.

2. $\quad$ El segundo define que el Wajontu mapu es una esfera pero que su mitad hacia arriba solo la podemos mirar, por lo tanto, nosotros los mapuches recreamos nuestra vida en una gran planicie que es casi la mitad del Wajontu mapu y que la otra mitad de la esfera que está abajo, es desconocida y sostiene al Naüq Mapu. Es por así decirlo como una manzana cortada en la mitad y que nosotros viviéramos en la superficie de las dos mitades.

3. La joya mapuche que utiliza en su construcción este concepto es la xapelakucha, la que en su placa única y principal grafica de manera armónica y equilibrada las cuatro tensiones y su cadena que la sostiene representa la espiritualidad que tenemos los mapuches con los newen generadores de la vida.

Nuestros antepasados antiguamente enseñaban este concepto a los niños y jóvenes de la siguiente manera: colocaban una gran rali con cuatro orificios equidistante del centro a los cuales se les colocaba unas cuerdas atados a cada orificio y luego cuatro niños tomaban de las cuerdas y al mismo tiempo y con la misma fuerza tiraban hacia sus cuerpo, cuando esto ocurría el plato quedaba suspendido en el aire, de esta manera se demostraba y se enseña el concepto. 


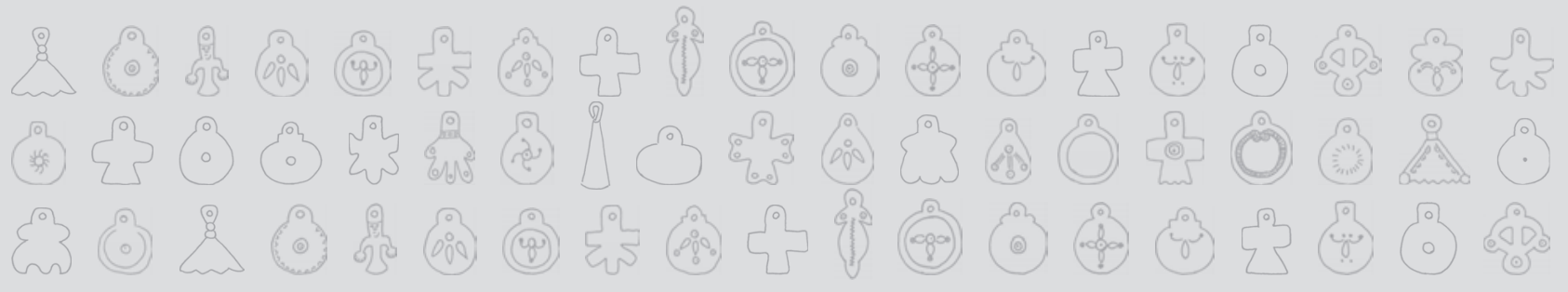

\section{Gráfico $N^{\circ} 11$}

Mostrar el gráfico completo, espacial y de las fuerzas que lo sostienen

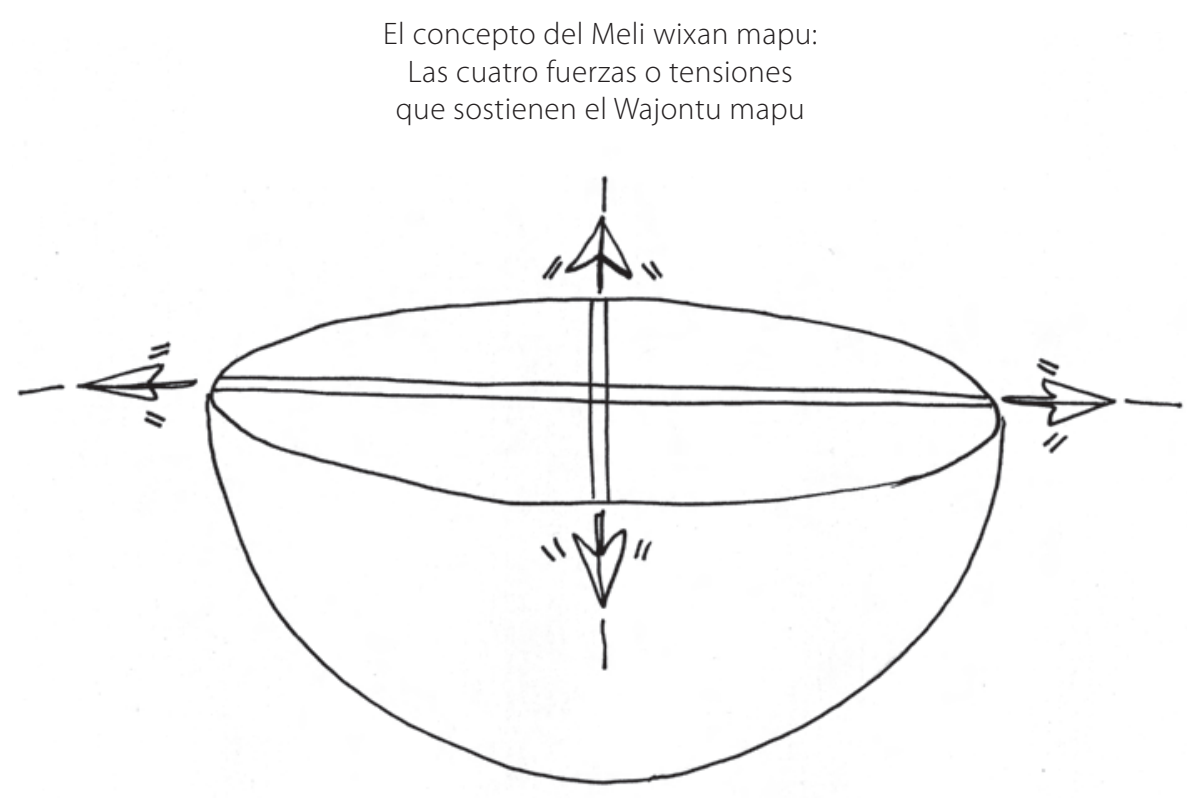

Las fuerzas o tensiones son equidistantes del centro y salen fuera del Wajontu mapu hacia el Waj mapu

\section{SÉPTIMA IDEA: CÓMO NACE EL PUEBLO MAPUCHE}

Según las narraciones que se han recopilado de nuestros ancianos y antepasados, se ha podido sintetizar una serie de ideas y conceptos que definen cómo aparecemos socialmente en el Naüq Mapu.

Nuestros ancianos dicen que hubo en un momento de nuestra vida como pueblo en el que dentro de nuestras actividades religiosas solo acostumbramos a 'pedir', a 'solicitar' a 'rogar' para el bienestar de las familias 'pero nos olvidamos de agradecer' por lo solicitado y dado por los newen creadores de la vida, esto produjo un desorden en los elementos que posibilitan la vida, o sea entre el ahtü (sol), ko (las aguas) y el Naüq, se produjo un descomplemento, un desequilibrio entre los tres. Hubo en el Naüq Mapu grandes cambios: erupciones de volcanes, salidas de mar, creación de cerros, grandes zonas se taparon de agua. Este gran cataclismo produjo muchas muertes en los mapuches y todo se transformó. Para calmar al Wajontu mapu se hicieron muchas rogativas y sacrificios hasta que todo volvió a la normalidad después de muchas lunas, a partir de esa experiencia los mapuches no podemos olvidar practicar nuestra espiritualidad y estar en equilibrio con las fuerzas creadoras de la vida. 
Esa generación de mapuche que les tocó vivir esos momentos, quisieron que no se olvidara y crearon un epew para ser enseñado a los niños y jóvenes mapuche, así nace Xeg Xeg filu y Kay Kay filu, que en lo central dice que hubo una gran pelea entre dos enormes culebras, una de agua llamada Kay Kay filu y otra de tierra llamada Xeg Xeg filu, estas enormes culebras no las veíamos, pero, cuando Kay Kay filu batía su cola en el mar formaba grande olas que cubrían grandes espacios de la tierra, muchos mapuches morían y algunos se transformaban en peces. Pero al mismo tiempo que esto sucedía la culebra de tierra Xeg Xeg filu también batía su cola y formaba grandes cerros a los cuales algunos mapuches subían y se salvaban. Así pasaron muchas lunas hasta que todo se calmó, volvió el complemento, el equilibrio y la reciprocidad entre el agua y el Naüq. Así quedaron cuatro personas mapuche, dos ancianos y dos jóvenes. Los ancianos kushe y fücha entregaron el conocimiento, la experiencia y la sabiduría y los dos jóvenes üjcha y weche entregaron la fortaleza, la vitalidad y la procreación así nacimos los mapuches como pueblo.

Este concepto se encuentra presente en varias graficaciones dentro de la Platería Mapuche, específicamente en los tupu y a veces en los xapelakucha.

\section{Gráfico $N^{\circ} 12$}

Mostrar en este las cuatro personas que posibilitan la creación del pueblo mapuche

El Piam del Xeg Xeg y Kay Kay explica

cómo se forma el pueblo mapuche

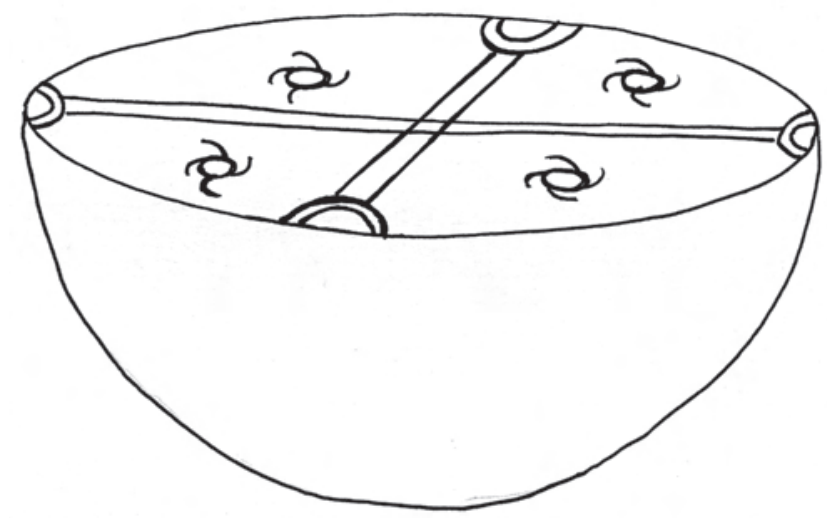

Kuse la anciana; Fücha el anciano üjcha la joven mujer; Weche el joven varón 


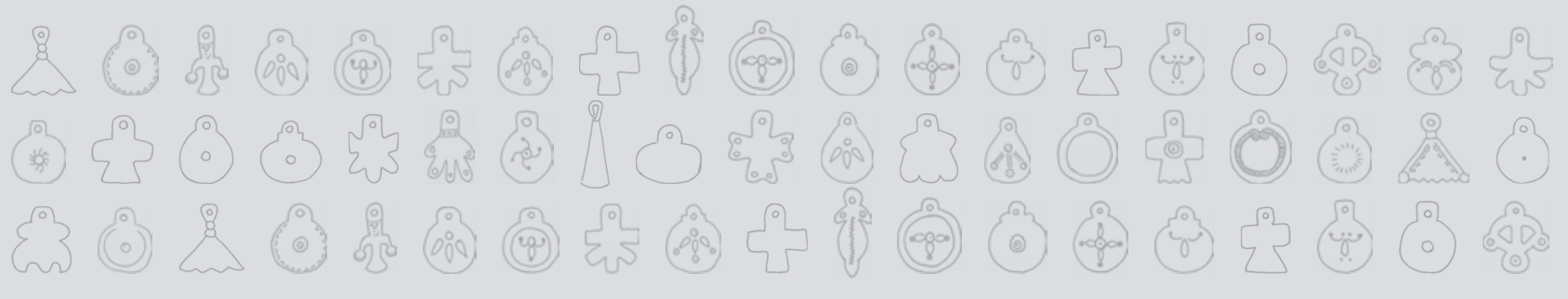

\section{INTERPRETACIÓN DEL XARILOGKO}

Una de las piezas de la Platería Mapuche de mayor uso y que aún se mantiene vigente hasta el día de hoy con mucha fuerza es el xarilogko.

El xarilogko representa la expresión de espiritualidad en los lofche, rewe y ayjarewe y que fundamentalmente se desarrolla en los gijatun. Es aquí donde las fuerzas de los newen que crearon la vida y la administran, los distintos newen de la naturaleza y de los che, interactúan como una gran fuerza en un mismo momento. Esto es lo que expresa el xarilogko.

Tiene un sentido de unidad, de pertenencia, en ella están incluidas todas las familias del lof que tienen un mismo tuwün y descienden de un mismo tronco familiar o küpalme, esto es fundamental para la definición de las formas del mismo así como de sus graficaciones, particular importancia tiene en la expresión espiritual de los mapuche el Füta El Mapu (identidades territoriales) ya que determina también formas y uso del xarilogko, aquí se considera los newen que ahí viven y los elementos más característicos de esos territorios, todo estos se considera a la hora de construir un xarilogko.

El uso del xarilogko, en la cabeza, expresa la forma gráfica del gijatun en su desarrollo, dejando la unión de ambos extremos de la pieza en la frente de la mujer mapuche, lo mismo que la entrada al gijatun.

El xarilogko tiene diversas formas según el Füta El Mapu al cual pertenezca y lo mismo sucede con los usos de la mujer mapuche en cuanto a actividades ceremoniales, matrimonio, funerales y vida normal que son distintos en los diferentes territorios.

Desde el punto de vista técnico de la construcción de los xarilogko, existe una variada gama de ellos: los hay de canastillos y amarras de plata, de placas con amarras dobles, de jüf jüf sobre fajas de lanas tejidas de distintos colores, puede darse esta misma variante pero sobre faja de cuero en estas dos últimas pueden estar combinadas con monedas antiguas y mostacillas de vidrio o metal, también pueden tener adosadas tubos de plata o placas de plata y en las terminaciones pueden tener colgado algunos chojol (campanas). Existen también algunos xarilogko que son diferentes a los tradicionales, particularmente en la zona de Arauko que se construye sobre una gran faja de lana de distintos colores que está unida en sus extremos a la cual se le adosan jüf jüf en una cantidad considerables.

Otra variante es el güxowe que hace las veces de xarilogko pero que a su vez toman de las trenzas de la mujer mapuche y se enrollan en ellas, su construcción es sobre una gran faja de lana de distintos colores que pueden llegar a medir cuatro metros de largo y a la cual se le adosan una cantidad de sobre 4.000 jüf jüf además de monedas, placas, tubos, choyol y chaquiras que lo hacen de una gran belleza, esta es una pieza que cobra fuerza y se despliega por el territorio mapuche durante casi todo el siglo XIX. 



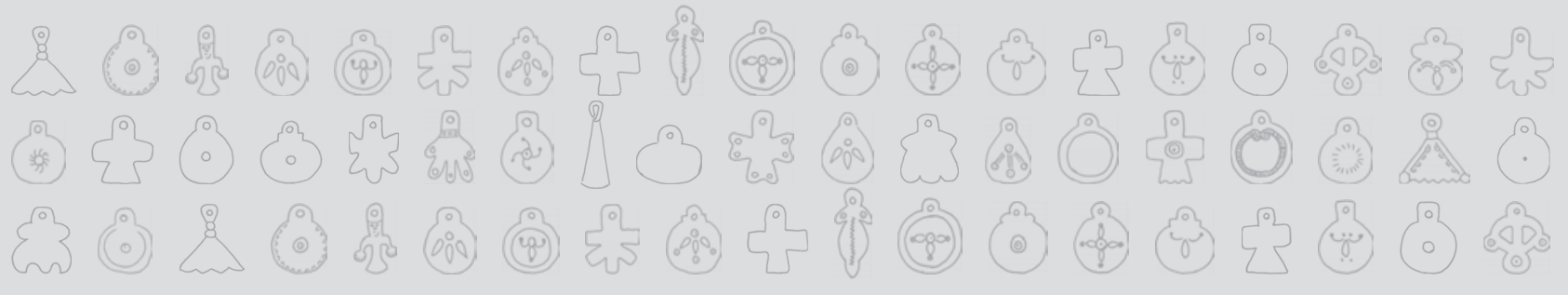

\section{Algunas consideraciones finales acerca de la Platería Mapuche}

En este ensayo se ha querido entregar de forma ordenada los fundamentos que son base para la posterior aparición de la Platería Mapuche. Hemos analizado de forma cronológica los distintos momentos por los que tuvo que vivir el pueblo mapuche a partir de la invasión Inka en los años 1400, pasando por la invasión española a partir del año 1541 y la última invasión del Estado chileno a partir de la década del 1850 y que culmina el año 1883, la que se mantiene hasta el día de hoy.

Todos y cada uno de estos momentos han producido profundos cambios en la sociedad y pueblo mapuche, que tiene que ver con lo económico, lo social y lo político. Sin lugar a dudas, en todas estas transformaciones se nutrió de todos aquellos elementos que fortalecía, proyectaba su vida a nuevos y mejores niveles de calidad, esto también se refleja en la aparición, desarrollo y esplendor de la Platería Mapuche.

La última etapa que todavía vivimos, determinó de forma brutal de lo que dio en llamarse la decadencia de la platería, no obstante esta situación, podemos decir que en los últimos 20 años, es decir desde el año 1991 hasta el día de hoy, se han creado condiciones para rescatar, desarrollar, fortalecer y proyectar la Platería Mapuche.

Este ensayo tiene como objetivo fundamental considerar desde la visión mapuche, los conceptos filosóficos contenidos en su kimün y en su rakizuam en la construcción de las joyas, esto es el aporte concreto que entregamos a este renacer de nuestra mapuche rüxan (Platería Mapuche).

Lo más probable es que falten muchos contenidos y particularidades del mapuche kimün en este trabajo, la invitación entonces a todos los rüxafe, autoridades mapuches y estudiosos del tema a aunar esfuerzos en pos de proyectar la Platería Mapuche más allá del siglo XXI. 



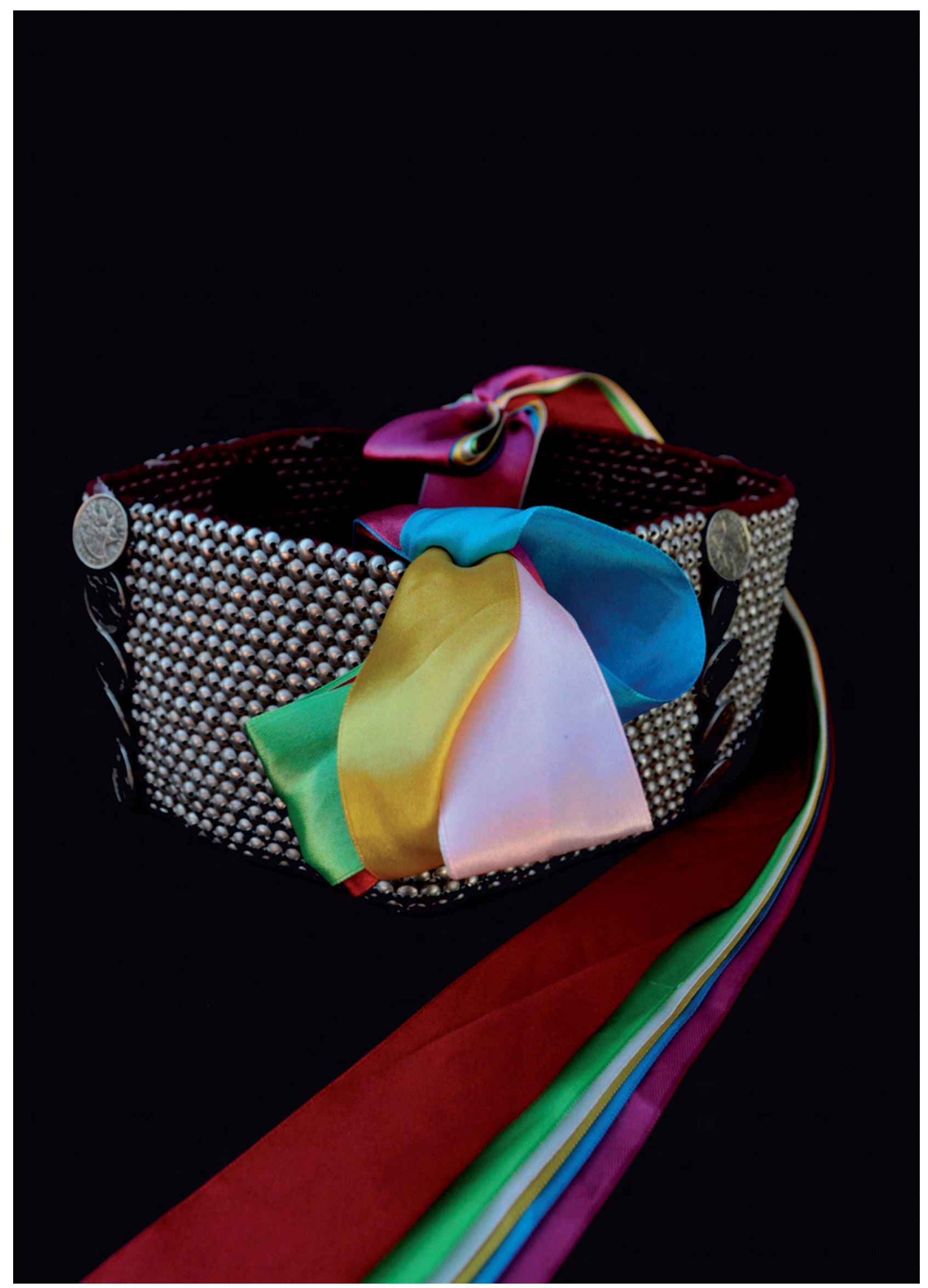



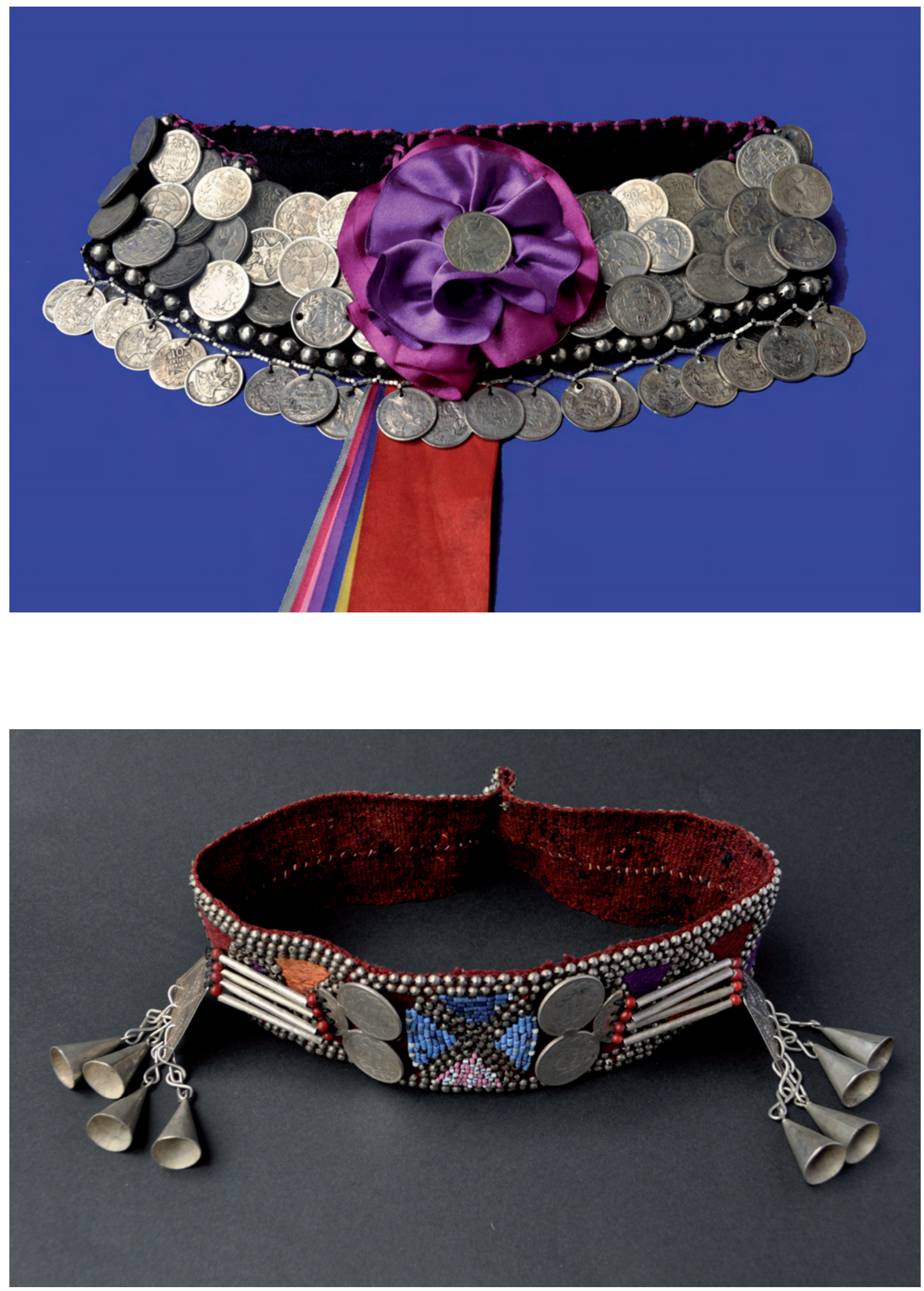


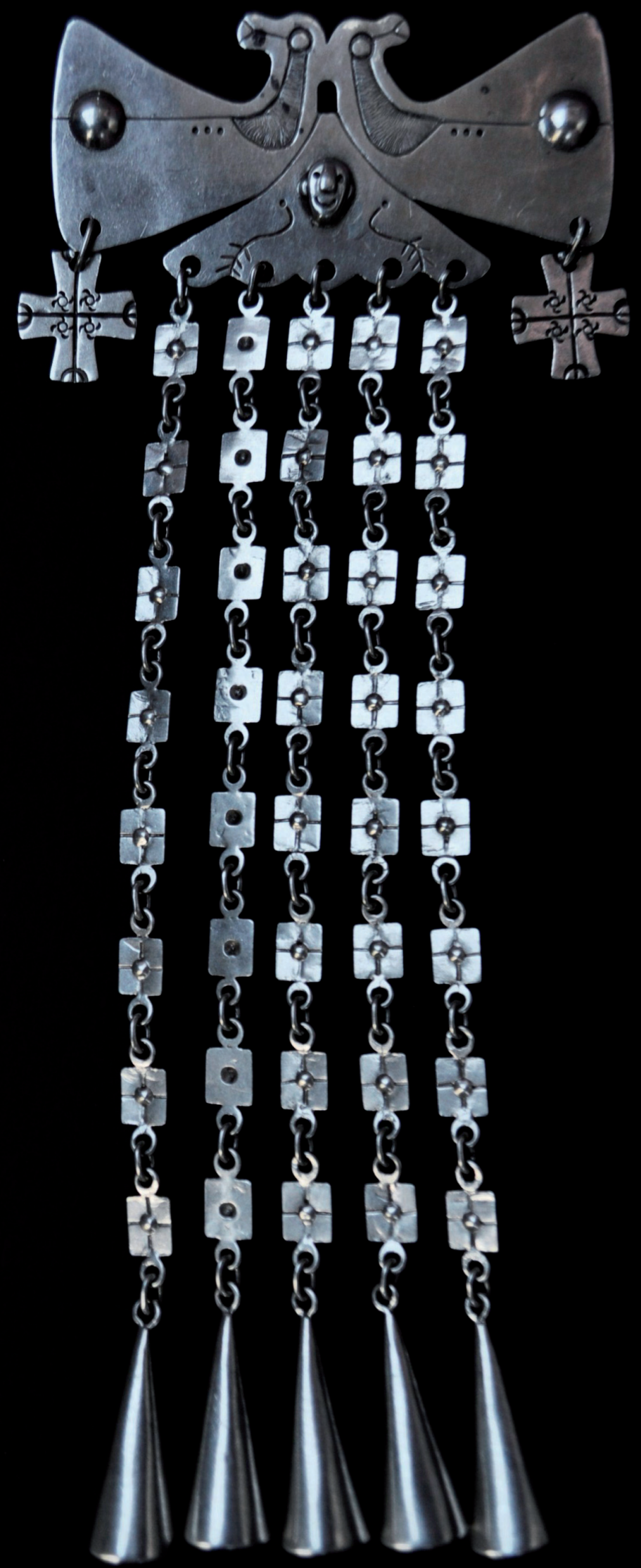




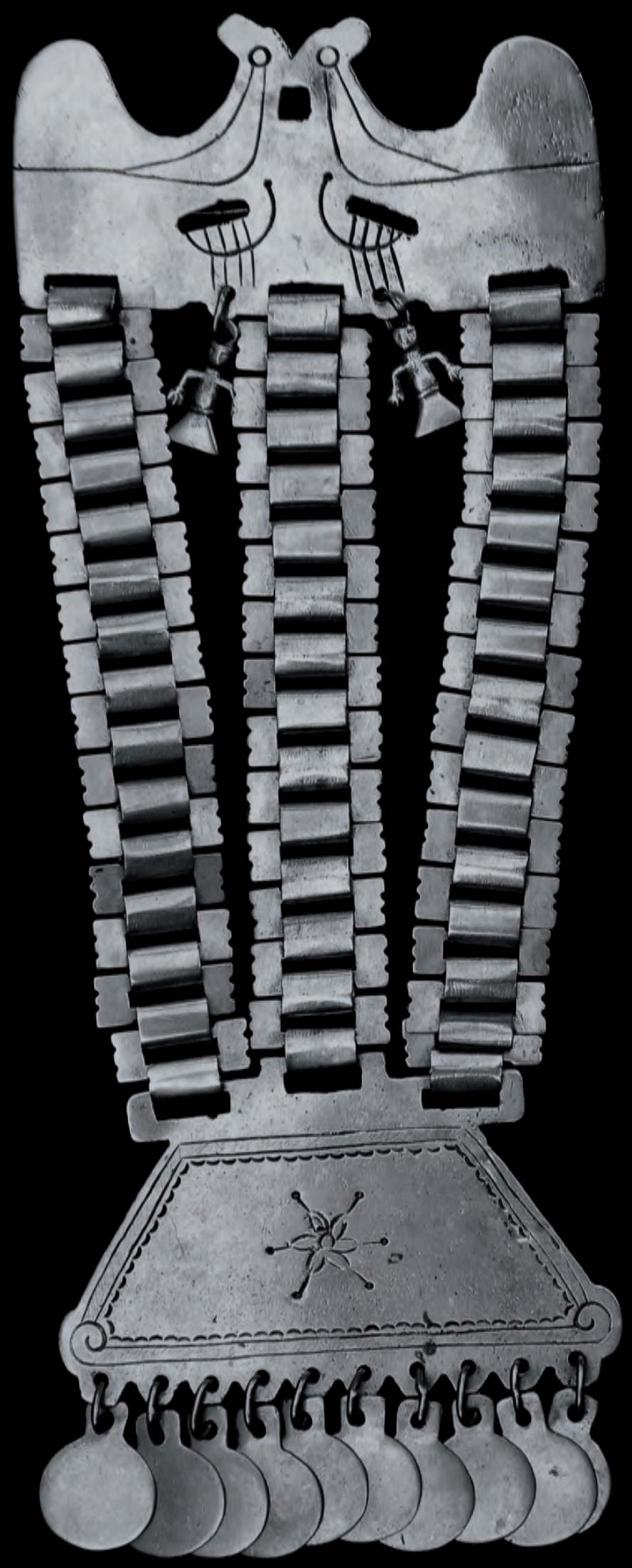




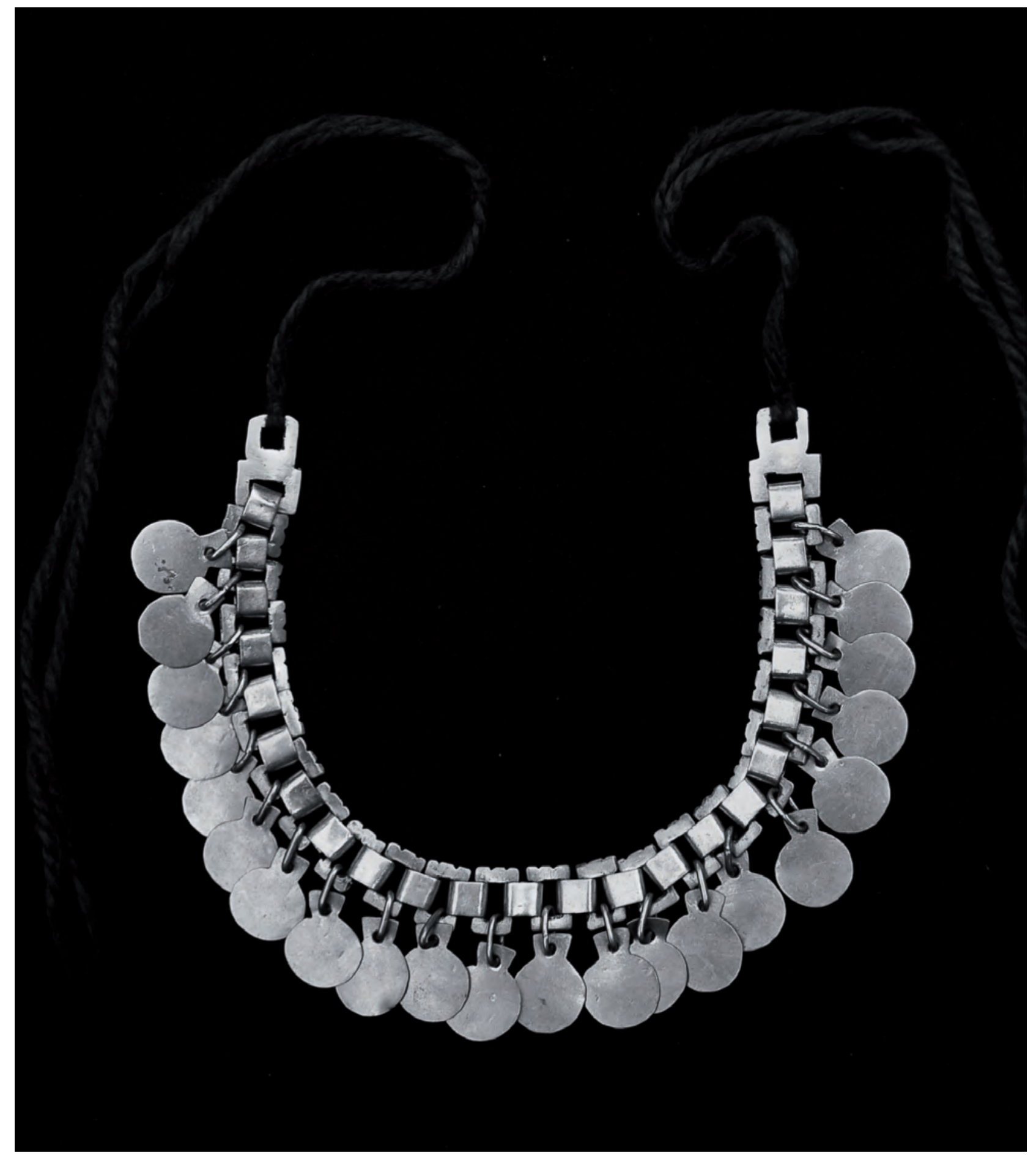



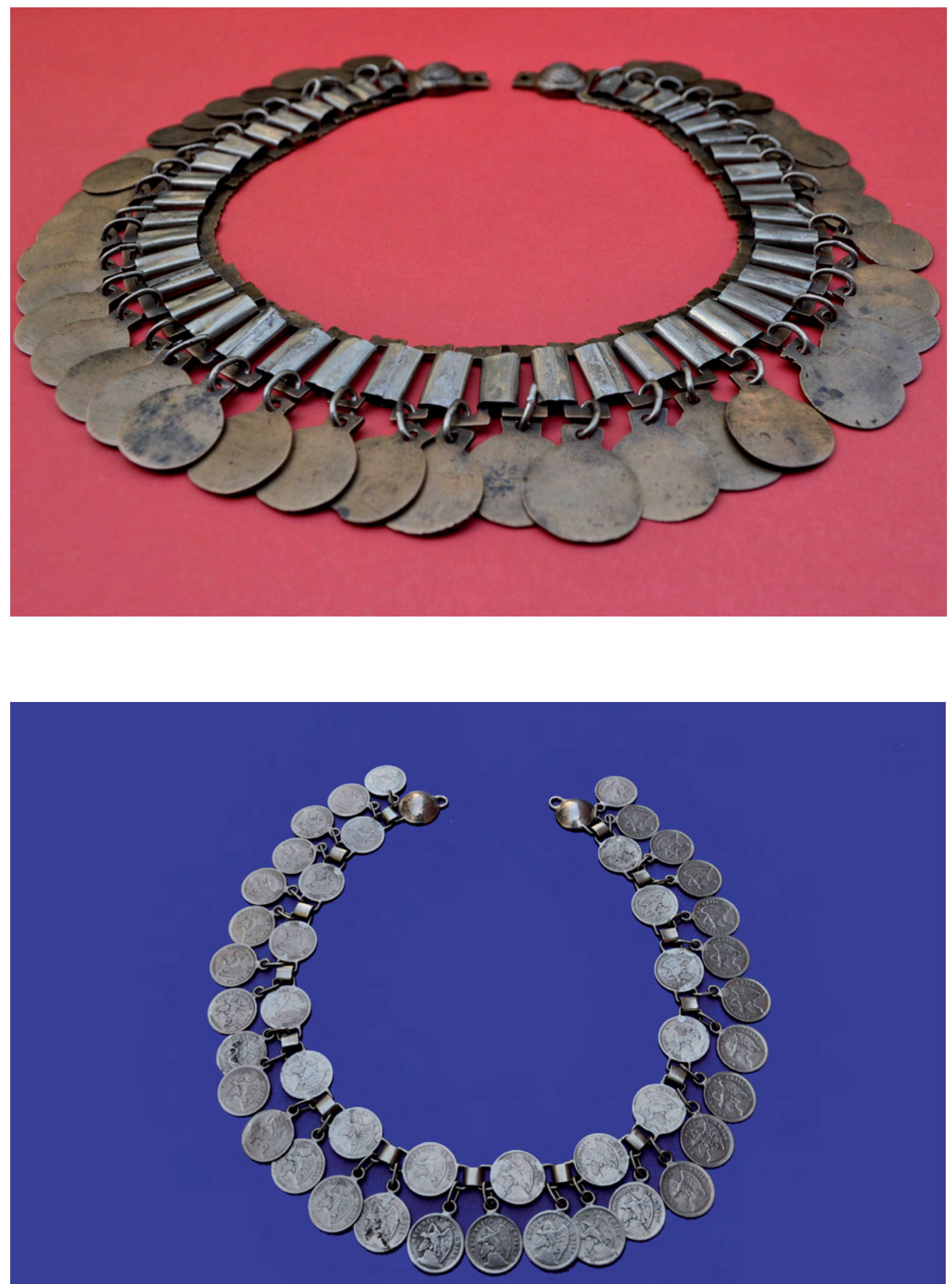


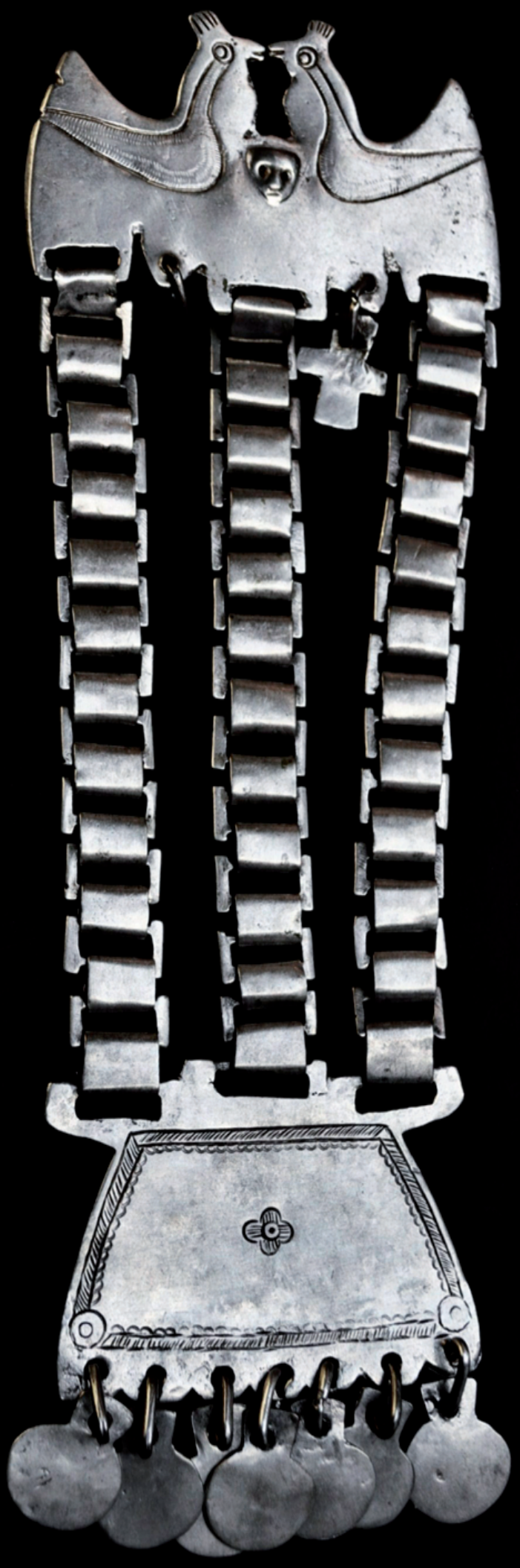



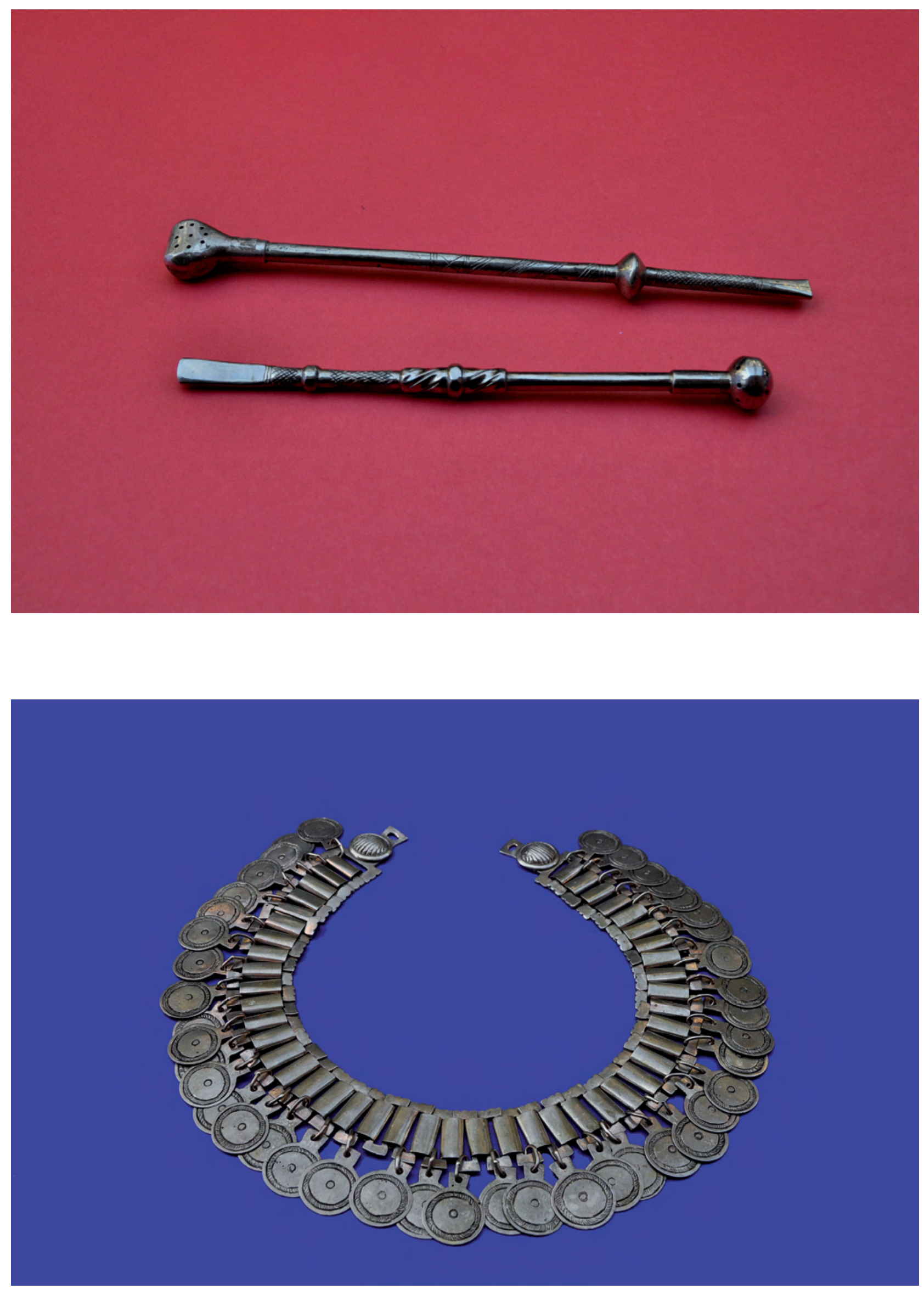


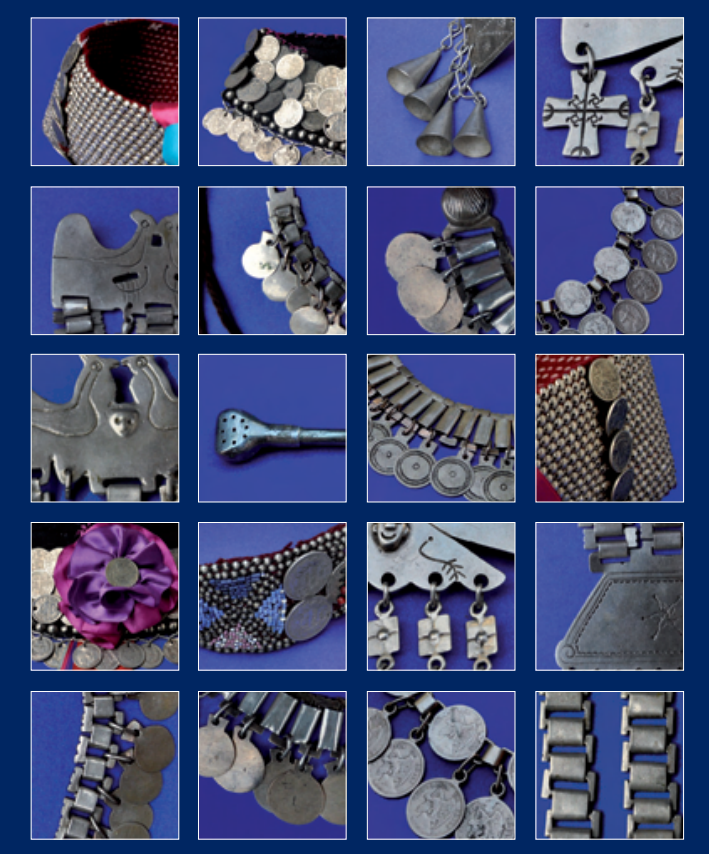

(...) Los rüxafe son los que trabajan los metales, los wizüfe son los que construyen formas en greda, pero no son subcategorías en la sociedad mapuche, que sí lo son en relación con el otro mundo no mapuche. Creo que el texto testimonial de Juan Antonio Painecura demuestra lo trascendente del arte mapuche del rüxan al explicar los significados que se imprimen en cada trabajo, en cada pieza de la riquísima expresión orfebre mapuche.

En este mismo tenor, creo que es importante destacar en este texto la posición clara, definida, que el autor toma acerca de ciertos temas que aún no han tenido una posición, como es el caso de hablar derechamente de "religión mapuche", sacando con ello a la expresión religiosa mapuche también de los submundos conceptuales a las que nos destinan la elite clasista e integracionistas. Sacarnos de la "religiosidad", de la "creencias", "espiritualidad", que no interpreta en plenitud el acervo religioso mapuche. Ahora bien, quizás la categoría de "religión" tampoco nos interprete plenamente, pero por lo menos estamos ubicándonos en peldaños conceptuales más simétricos para entrar a dialogar en serio con las otras sociedades. Pero la discusión no está terminada, este texto es una clara provocación a la reflexión, a la discusión, una invitación a tomar posiciones a partir de un ensayo basado en la expresión artística (...)

José Quidel Lincoleo

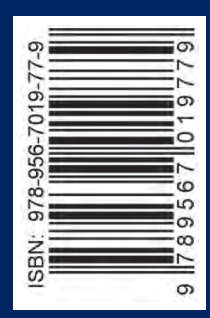

